\title{
Expanding Democracy - Transferring the Crown Prerogative to Parliament
}

\author{
Graham S McBain ${ }^{1,2}$ \\ ${ }^{1}$ Peterhouse, Cambridge, UK \\ ${ }^{2}$ Harvard Law School, USA \\ Correspondence: Graham S McBain, 21 Millmead Terrace, Guildford, Surrey, GU2 4AT, UK. E-mail: \\ gsmcbain@aol.com
}

Received: November 19, 2013 Accepted: December 2, 2013 Online Published: January 16, 2014

doi:10.5539/res.v6n1p83

URL: http://dx.doi.org/10.5539/res.v6n1p83

The world is changing fast and the law - and legal systems - need to keep abreast of changing social mores and customs. Also, since the power of the State is growing, there should be an increasing emphasis on human rights by way of counter balance.

Many legal systems - including the English legal system and its Commonwealth variants - contain large amounts of legal material rooted in Victorian, and more ancient, times. Material which is of little - or no - service today. Further, a lot of English and Commonwealth law is voluminous, obscure and contradictory. Nowhere is this more apparent than in the constitutional field. The topic is bedevilled with fragmented legislation and extra-legal conventions. There is also the 'Crown prerogative' - an area of law out of sync with the present age where the Queen now only possesses a formal role. Unfortunately, much of the Crown prerogative has flowed into Commonwealth legal systems.

It is asserted that the Crown prerogative is the greatest legal impediment today to the continuing development of human rights. It comprises a mass of legal acts undertaken by government for which there is neither accountability to Parliament nor oversight by the same. Although these acts are said to be done in the name of 'the Crown,' the sovereign herself neither knows about them nor is she able to do anything if they are illegal or defective.

The purpose of this article is to assert that this does not need to be so and that it can be remedied relatively easily. Large numbers of Crown prerogatives are obsolete. They should be abolished. The remainder should be transferred to Parliament so that all governmental acts are subject to the oversight of the duly elected representatives of the people.

\section{$\underline{\text { Abstract }}$}

In early times, the English legal system accorded to the sovereign many prerogatives (privileges). This was usually to enhance his status, to reflect his pre-eminence. Or it was to provide funds for him, to pay for matters under his control - such as his courts, army and navy. Over time, many of these Crown prerogatives have become uncertain, confused and obsolete. The purpose of this article is consider a number of these prerogatives and to argue either for their abolition or their transfer to Parliament.

In respect of Crown prerogatives relating to the courts it is asserted that prerogatives to: (a) establish common law courts; (b) sit as a judge; (c) withdraw any matter of State from the cognisance of a court; (d) request any judge to delay giving judgment; (e) sue in whatever court the sovereign pleases; (f) be exempt from court costs; (g) possess immunity from criminal prosecution - should be abolished. Also, that the civil immunity of the sovereign should be lifted, in part.

In respect of Crown prerogatives relating to the military it is asserted that prerogatives to make - and declare -war and peace should pass to Parliament. And that prerogatives to: (i) impress subjects for the navy; (ii)issue letters of reprisal and marque; (iii) issue letters of safe conduct; (iv)prohibit subjects from leaving the realm; (v) order subjects to return to the realm; (vi) dig for saltpetre (for gunpowder); (vii) impose martial law; 
(viii)prohibit subjects from building castles (or enter the land of other subjects to erect fortifications for the defence of the realm in war time) - should be abolished. Also, that any Crown prerogative to erect fortifications should be replaced by legislation, where required.

In respect of Crown prerogatives relating to public functions, it is asserted that the Crown prerogative to compel a person to accept a public office should be abolished. And that any residual functions of the Crown to act as parens patriae should be transferred to Parliament.

In respect of the Crown prerogative to make legislation in the form of issuing proclamations, it is asserted they should be replaced by Statutory Instruments, in order for Parliament to have control over the matter.

Keywords: Crown prerogatives, transfer to Parliament, common law courts, sovereign and her courts, immunity of the sovereign, parens patriae, making and declaring war and peace, subordinate military prerogatives, prohibition on erecting castles, obligation to accept a public office, issuing proclamations.

\section{$\underline{\text { Introduction }}$}

Democracy is fragile. The idea that every adult has an equal right to freely express their opinion took a battering last century. It required two World Wars - and a multitude of smaller ones - to defend it. Indeed, the fact that, today, there still exist a multitude of dictatorships (or quasi-dictatorships) around the word attests to the grim reality that democracy still has a long way to go, in order to become the global norm. In the battle for democracy the role of Parliaments - as well as that of the courts - is essential. The one to ensure that laws reflect democracy and its offshoot, human rights. The other to ensure that the laws are applied equally and impartially to all citizens and that any legal privileges accorded to the few are justified.

- However, for Parliament to carry out its role in reflecting the will of the people it, alone, should have the right to pass laws and to grant legal privileges;

- Further, it alone should be accountable to the people for all acts of the government. Otherwise, such acts are carried out without the affirmative sanction of the people through its primary elective institution, Parliament.

In the case of England - as well as Commonwealth countries founded on its legal system - a major impediment to deepening democracy is that many legal acts are still carried out in the name of the 'Crown' although the sovereign, in person, sanctions none of this and has only a formal role. Thus, bureaucrats - the servants of the government - execute these things in the sovereign's name. But to whom are they accountable? Not to the sovereign since she is powerless to hold them to account. ${ }^{1}$ Nor to Parliament since it does not sanction these acts in legislation - whether primary or secondary.

- As a result, a multitude of Government acts and decisions which affect the general public occur, legally, by way of a 'sidewind';

- Crown prerogatives comprise special privileges accorded to the sovereign and exercised in her name. They are a remnant of history preserved only since there has been a failure - to date - to abolish the obsolete ones ${ }^{2}$ as well as replace those still of validity with legislation. Is this a good thing? The answer is ' $n o$ ' and a House of Commons report in 2004 made it clear that something should be done about it. ${ }^{3}$

Part of the problem is the paucity of legal analysis as to what prerogatives still exist, as well as their nature and extent. The results are surprising. The Crown still retains many prerogatives - both of an immediate and a residual nature - which impose burdens on the public. Burdens for which - if Parliament sought to impose them today - they would secure no democratic mandate. True, many of these are obsolete. However, others comprise major powers which only Parliament should hold.

\footnotetext{
${ }^{1}$ Halsbury, Laws of England (4th ed, with updates), vol 8(2), para 8 'the powers of government are distributed among a number of institutions, so that the original concentration of power in the monarch no longer exists.' AW Bradley \& KD Ewing, Constitutional and Administrative Law (15th ed, 2011), p 33 'The Queen may reign, but it is the prime minister and other ministers who rule.'

${ }^{2}$ Ibid, n 1, para $368 \mathrm{n} 7$ 'Although there is no such doctrine that a prerogative may cease to exist because it is not used, many old prerogative powers, even if not actually abolished by statute, have become clumsy and antiquated and have fallen into disuse.'

${ }^{3}$ House of Commons, Public Administration Select Committee. 4th Report of Session 2003-4. Taming the Prerogative: Strengthening Ministerial Accountability to Parliament. HC 422 (16 March 2004) ('HC').
} 
- At the outset it may be noted ' $w h y$ ' it is important to remove obsolete prerogatives as well as transfer the remainder to Parliament. The UK's constitutional law is incomplete and piecemeal. ${ }^{4}$ This incompleteness is reflected in many Commonwealth systems;

- In the past, this may not have been too much of a problem. In modern times, with a great increase in the volume of law - and a greater emphasis on (and need for) human rights - this is most unsatisfactory and should not continue. The law should be a model of clarity; not swirling and turbulent waters.

The purpose, therefore, of this two-part article is to consider 'Crown prerogatives' and to demonstrate why a large number of them should be abolished. The remaining prerogatives which still retain validity should be transferred to Parliament, so that it is accountable for them to the general public. When analysing Crown prerogatives that still exist, the Abridgments - major ${ }^{5}$ and minor $^{6}$ - contain material, by way of summary. Of greater use, however, are the following legal texts:

- $\quad$ Coke, Institutes of the Laws of England (1628-41);

- Blackstone, Commentaries on the Laws of England (1765-9); ${ }^{8}$

- Halsbury, Laws of England; ${ }^{9}$

- J Chitty Jun, A Treatise of the Law of the Prerogatives of the Crown (1820). ${ }^{10}$

There are also a number of old ${ }^{11}$ - and modern ${ }^{12}$ - texts on constitutional law which are of use. These include legal histories on the constitution. ${ }^{13}$

\footnotetext{
${ }^{4}$ Halsbury, n 1, para 1 'United Kingdom constitutional law is an incomplete system, consisting of piecemeal legislation, ancient common law doctrines, and constitutional conventions which are binding in a political rather than a legal sense. The United Kingdom constitution lacks the coherence of comprehensive written constitutions.'

${ }^{5}$ N Statham, Abridgment of the Law (Pynson, London, c. 1490); A Fitzherbert, La Graunde Abridgment (Tottell, London, $3^{\text {rd }}$ ed 1577); R Brooke, La Graunde Abridgment (Tottell, London, 1586); H Rolle, Abridgment des plusieurs Cases et Resolutions del Common Ley (A Crooke et al, 1668).

${ }^{6}$ W Hughes, Grand Abridgment of the Law (Henry Twyford etc al, London, 1660-3); W Sheppard, Grand Abridgment of the Common and Statute Law of England (George Sawbridge et al, London 1759); W Nelson, Abridgment of the Common Law (E \& R Gosling, London, 1725-6); M Bacon, New Abridgment of the Law (ed H Gwillim, London, $5^{\text {th }}$ ed, 1798); E Viner, A General Abridgment of the Law and Equity (GCJ \& J Robinson, London, 2nd ed, 1791, reprinted by Law Book Exchange); J Comyns, Digest of the Laws of England (A Hammond, last
} ed, 1822); J Lilley, Practical Register ( $2^{\text {nd }}$ ed, 1765).

${ }^{7}$ E Coke, Institutes of the Laws of England (W Clarke \& Sons, London, last ed, 1824).

${ }^{8}$ W Blackstone, Commentaries on the Laws of England (Oxford, Clarendon Press, ${ }^{\text {st }}$ ed, 1765-9, University of Chicago Press rep 1979).

${ }^{9}$ Halsbury, n 1. See also W Holdsworth, A History of English Law (Longmans rep, 2009).

${ }^{10} \mathrm{~J}$ Chitty Jun, A Treatise of the Law of the Prerogatives of the Crown (Butterworths, London, 1820). See also W Staunford, An Exposition of the King's Prerogative (Company of Stationers, 2nd ed, 1607); Sir Matthew Hale's Prerogatives of the King, DEC Yale (ed) Selden Society, vol 92 (London, 1976) and T Brecknock, Droit le Roy (London, W Griffin, 1764).

${ }_{11}$ See Sweet and Maxwell, A Legal Bibliography of the British Commonwealth of Nations (2nd ed, 1955), vol 1 for works pre-1800 and vol 2 for works 1900-55. Useful material includes: J Allen, Inquiry into the Rise and Growth of the Royal Prerogative in England (London, Longman Green, 1849); LS Amery, Thoughts on the Constitution (Oxford UP, 2nd ed, 1953); WR Anson, The Law and Custom of the Constitution (Oxford, Clarendon Press, 5th ed, 1922); G Bowyer, The English Constitution (London, James Burns, 1841); ES Creasy, The Rise and Progress of the English Constitution (Macmillan \& Co, 17th ed, 1907); AV Dicey, Introduction to the Study of the Law of the Constitution (Macmillan \& Co, 9th ed, 1948); H St C Feilden, A Short Constitutional History of England (Oxford,1911); RFV Heuston, Essays in Constitutional Law (Stevens, 2nd ed, 1964); WI Jennings, The British Constitution (Cambridge UP, 5th ed, 1968); WI Jennings, The Law and the Constitution (University of London, 5th ed, 1959); WI Jennings, Cabinet Government (CUP, 1969); HJ Laski, Reflections on the Constitution (Manchester UP, 1951); HWR Wade, Constitutional Fundamentals (Stevens \& Sons, 1980); HO Wakeman \& A Hassall, Essays Introductory to the Study of English Constitutional History (Longmans, 1896).

12 J Alder, Constitutional and Administrative Law (Palgrave Macmillan, 9th ed, 2013); M Amos, The English Constitution (Longmans, 1930); H Barnett, Constitutional and Administrative Law (Routledge, 10th ed, 2013); E Barendt, An Introduction to Constitutional Law (OUP, 1998); V Bogdanor, The Monarchy and the Constitution (Oxford, Clarendon Press, 1995); Bradley, n 1; R Brazier, Constitutional Practice (Clarendon Press, Oxford, 2nd ed, 1994); SA De Smith \& R Brazier, Constitutional and Administrative Law (Penguin, 8th ed, 1998); D Chalmers \& C Asquith, Outlines of Constitutional Law (London, Sweet \& Maxwell, 1936); O Hood Phillips \& Jackson, Constitutional and Administrative Law (Sweet \& Maxwell, 8th ed, 2001); DL Keir \& FH Lawson, Cases in Constitutional Law (Clarendon Press, 6th ed, 1979); P Leyland, The Constitution of the United Kingdom (Oxford \& Portland, Oregon, 2012); G Marshall, Constitutional Theory (Oxford, Clarendon Press, 1971); JDB Mitchell, Constitutional Law (Scottish University Law Institute/W Green \& Sons, 2nd ed, 1968); CR Munro, Studies in Constitutional Law (Butterworths, 2nd ed, 1999); O Hood Phillips \& Jackson, Constitutional and Administrative Law (Sweet \& Maxwell, 8th ed, 2001); A Le Sueur, M Sunkin \& JEK Murkens, Public Law (Oxford UP, 2nd ed, 2013); M Sunkin \& S Payne (eds), The Nature of the Crown: A Legal and Political Analysis (OUP,1999) ('Sunkin'); A Tomkins, Public Law (Oxford UP, 2003); C Vincenzi, Crown Powers. Subjects and Citizens (Pinter, 1998).

${ }^{13}$ SB Chrimes, English Constitutional History (Oxford UP, 2nd ed, 1949); JEA Jolliffe, The Constitutional History of Medieval England (Adam \& C Black, 2nd rep, 1948); DL Keir, The Constitutional History of Modern Britain (Adam \& C Black, 2nd ed 1945); A Berridale Keith, The Constitution of England from Queen Victoria to George VI (Macmillan \& Co, 1940); A Berridale Keith, The King and the Imperial Crown (Longmans, 1936) ('Keith'); FW Maitland, Constitutional History of England (Cambridge UP, 1st ed, 1908); TE May, The Constitutional History of England (Boston, Crosby \& Nichols, 1862 ed); EW Ridges, Constitutional Law of England (Oxford, Clarendon Press, 5th ed, 1934); CG Robertson, Select Cases and Documents (Methuen \& Co Ltd, 7th ed, 1935); CW Stubbs, The Constitutional History of England (4th ed, 1883); JR Tanner, English Constitutional Conflicts of the Seventeenth Century 1603-1689 (Cambridge UP, 1962); P 


\section{Meanings: Crown \& Crown Prerogative}

\section{(a) Concept of the 'Crown'}

The concept of the 'Crown' can be misleading. It may refer to the sovereign in person. Or it may refer to various institutions of government of which she is (nominally) the head and for whose acts she is (nominally) responsible. Generally, reference to the Crown, today, tends to be to the latter. ${ }^{14}$ Halsbury notes this - as well as the fact that the 'Crown' may also refer to the servants of the same. Thus, it states:

Much of the business of central government is carried on in the name of 'the Crown.' The term 'the Crown' has a number of meanings. Historically, it referred to the monarch in who were united executive, legislative and judicial functions. Thus, it may be used to refer to the person of the monarch, although this is less commonly used in modern parlance. ${ }^{15}$ More frequently 'the Crown' refers to the executive or government. The Crown in this sense is in law a corporation sole or aggregate. ${ }^{16}$ However, the term 'the Crown' may also be used to apply to an officer or servant of the Crown, or to a minister acting in an official capacity. ${ }^{17}$

The different meanings of the Crown simply reflect the fact that - over the centuries - the power of the sovereign in person has diminished - and is diminishing ${ }^{18}$ - while the power of the government and other institutions who 'act' in her name (though not, necessarily, with her personal knowledge or assent) has increased - and is increasing. Thus, as Lord Diplock pointed out in Town Investments (1978):

to continue nowadays to speak of 'the Crown' as doing legislative or executive acts of government, which, in reality as distinct from legal fiction are decided on and done by human beings other than the Queen herself, involves risk of confusion...I believe that some of the more Athanasian-like features of the debate in your Lordships' House could have been eliminated if instead of speaking of 'the Crown' we were to speak of 'the government' - a term appropriate to embrace both collectively and individually all of the ministers of the Crown and parliamentary secretaries under whose direction the administration of government is carried on by the civil servants employed in the various government departments... ${ }^{19}$

\section{(b) Crown Prerogatives}

Legal rights specific to the Crown are denominated its 'prerogatives, ${ }^{20}$ They are said to derive from common law, ${ }^{21}$ although - in truth - they pre-date the common law. ${ }^{22}$ Blackstone (writing in 1765) stated:

Taswell-Langmead, English Constitutional History (Sweet \& Maxwell, 11th ed, 1960); MA Thomson, A Constitutional History of England 1642-1801 (Methuen \& Co, 1938); B Wilkinson, Constitutional History of Medieval England 1216 - 1399 (Longmans, 1958).

${ }^{14}$ Halsbury, n 1, para 15 'The expression 'the Crown' may be used to refer either to the monarch or to the executive. Nowadays, it is used primarily to refer to the latter and to the executive powers of the monarch in whose name many of the activities of government are carried on.' See also Bank voor Handel v Slatford [1952] 1 AE 314, 319 per Devlin J. Also, Phillips, n 12, p 308.

${ }^{15} \operatorname{Re} M$ [1994] 1 AC 377 at 395 per Lord Templeman 'The expression 'the Crown' has two meanings: namely the monarch and the executive.' Also, at p 551 per Lord Woolf. See also Munro, n 12, p 255.

${ }^{16}$ Ibid. Also, Town Investments Ltd v Dept of the Environment [1978] AC 359. See also Blackstone, n 8, vol 1, pp 457-8.

${ }_{17}^{17}$ Halsbury, n 1, para 353. See also Sunkin, n 12, pp 23-4, ch 13.

${ }^{18}$ Munro, n 12, p 256 'For practical purposes, power has passed from the monarch to the politicians.' Halsbury, n 1, para 367, n 4 'The use of the term 'the Crown' conveys the correct implication that prerogative powers are, with very few exceptions, exercised not by the monarch in person but in her name by her servants. Even where the monarch acts in person, she normally acts in accordance with the advice given to her by ministers.'

${ }_{19}$ Town Investments Ltd $v$ Dept of the Environment [1978] AC 359 at pp 380-1. Munro, n 12, p 255 'the concept of the Crown is a convenient abstraction. The concept of 'the State', which is part of the intellectual furniture in many other countries, is relatively unfamiliar in legal and political discourses in Britain, in part because the concept of the Crown has served as a functional equivalent.'

${ }^{20}$ Whether Crown prerogatives should - in strict terms - be categorised as 'rights' (privileges) or 'powers' (authorities) is an interesting issue, but one which need not be addressed here.

${ }^{21}$ Case of Proclamations (1611) 12 Co Rep 74, 76 (77 ER 1352) 'the king hath no prerogative, but that which the law of the land allows him.'(spelling modernised). Staunford, n 10, p 2 'parliament maketh no part of the king's prerogative, but long time before it had his [its] being by order of the common law.' Ridges, n 13, p 184 'the prerogative forms part of the common law, and the courts have frequently adjudicated upon its extent.' Halsbury, n 1, para 368 'The prerogative is...derived from and limited by the common law.'

${ }_{22}$ Dicey, n 11, p 424 'The prerogative appears to be both historically and as a matter of actual fact nothing else than the residue of discretionary and arbitrary authority, which at any given time is left legally in the hands of the Crown.' Halsbury, n 1, para 368, n 1 'Historically it is incorrect to say that the prerogative is 'created' by the common law, because it is the residue of royal authority left over from a time before it was effectually controlled by law; but, since the time of Bracton, who founded the royal authority on law...it has been legally correct to use that term.' H Bracton (trans Thorne), On the Law and Customs of England c.1240 (Cambridge UP, 1968-76), vol 2, p 33 
By the word prerogative, we usually understand that special pre-eminence, which the king hath, over and above all other persons, and out of the ordinary course of the common law, in right of his regal dignity. It signifies in its etymology (from prae and rogo) something that is required or demanded before, or in preference to, all others. And hence it follows, that it must be in its nature singular and eccentrically: that it can only be applied to those rights and capacities which the king alone enjoys. ${ }^{23}$

As to Crown prerogatives, they have certain basic characteristics:

- Being derived from - and limited by - the common law, the sovereign can claim no prerogatives except such as the common law allows; ${ }^{24}$

- They have been frequently re-formulated, limited or abolished by legislation; ${ }^{25}$

- Where legislation governs, it precludes the prerogative, ${ }^{26}$

- They are subject to appraisal by the courts who may inquire into their existence or extent. However, they may not expand them; ${ }^{27}$

- $\quad$ They cannot be affected - or parted with - by the Crown, except as a result of express statutory authority. Some, however, may be franchised; ${ }^{28}$

- They extend to all parts of the Commonwealth of which the Queen is sovereign unless this is provided otherwise in United Kingdom (UK) - or local - legislation. ${ }^{29}$

\section{Classification - Crown Prerogatives}

Halsbury provides a fairly rudimentary classification of Crown prerogatives. ${ }^{30}$ This classification does not help much, given their varied nature. In order to cover their relative importance today - as well as their vitality - it is

'rex non debet esse sub homine sed sub deo et sub lege, quia lex facit legem' ('the king ought not to be subject to man, but to God, and to the law, for the law maketh the king.'). See also Blackstone, n 8, vol 1, p 232 and Chitty, n 10, p 5. Also, Bill of Rights 1688 'the laws of England are the birthright of the people thereof; and all the kings and queens who shall ascend the throne of this realm, ought to administer the government of the same, according to the said laws.'

${ }^{23}$ Blackstone, n 8, vol 1, p 232. Coke, n 7, vol 1, 90b, The king's prerogative 'extends to all powers, pre-eminences, and privileges which the law gives to the Crown' (spelling modernised). Halsbury, n 1, para 367. 'The royal prerogative may be defined as being that special pre-eminence which the monarch has over and above all other persons by virtue of the common law, but out of its ordinary course, in right of her regal dignity, and includes all the special dignities, liberties, privileges, powers and royalties allowed by the common law to the Crown of England.' A-G v De Keyser's Royal Hotel [ 1920] AC 508 at p 571 per Lord Parmoor 'Royal prerogative implies a privilege in the Crown of a special and exclusive character.' See also citations in GS McBain, Abolishing Obsolete Crown Prerogatives relating to the Military (2011) Nottingham LJ, vol 20, pp 14-5. Munro, n 12, p 256 'The royal prerogative may be defined as comprising those attributes belonging to the Crown which are derived from common law, not statute, and which still survive.' Chitty, $\mathrm{n} 10$, p 4 'if once any one prerogative of the Crown could be held in common with the subject, it would cease to be prerogative any longer.' See also Phillips, n 12, pp 305,310 and Bradley, n 1, p 246. Cf. Sunkin, n 12, p 30, ch 4 .

${ }^{4}$ Halsbury, n 1, para 368. Comyns, n 6, vol 7, p 42, Prerogative $A$ 'For the king has not any prerogative, but such as the law allows.' See also Case of Proclamations (1611) 12 Co Rep 74 (77 ER 1352).

${ }^{25}$ Chrimes, n 13, p 19 'Any Act of Parliament can destroy, modify, or impliedly supersede any part of the royal prerogative...' Halsbury, n 1, para 368, 'no prerogative may be recognised that is contrary to Magna Carta or any other statute, or that interferes with the liberties of the subject. Ex p Barnsley (1744) 3 Atk 168 (26 ER 899) at 171 per Lord Hardwicke LC 'the prerogative of the Crown...cannot be altered but by Act of Parliament.' See also Case of Proclamations (1611) 12 Co Rep 75 (77 ER 1352) at p 75 and Coke, n 7, vol 2, pp 36, 54. The Crown usually prefers to act under definite statutory powers. See also Munro, n 12, p 257 and Phillips, n 12 , p 307.

${ }^{26}$ Halsbury, n 1, para 369 'Where, by statute, the Crown is empowered to do what it might previously have done by virtue of its prerogative it can no longer act under the prerogative, and must act under and subject to the conditions imposed by the statute; but the statute may expressly preserve the right to act under the prerogative. Where a prerogative power has been superceded by statute, and the statutory provision is later repealed the prerogative will not revive unless it is a major governmental attribute.' Munro, $\mathrm{n} 12$, $\mathrm{p} 258$ 'new rights or powers may be conferred by statute, but these would then be not prerogative, but statutory powers.'

${ }^{27}$ Ibid, para 368. 'The courts have jurisdiction...to inquire into the existence or extent of any alleged prerogative, it being a maxim of the common law that the king ought to be under no man, but under God and the law, because the law makes the king [see Bracton, $\mathrm{n}$ 22]. If any prerogative is disputed, the courts must decide the question whether or not it exists in the same way as they decide any other question of law. If a prerogative is clearly established, they must take the same judicial notice of it as they take of any other rule of law.' See also paras 379-80. BBC v Johns [11965] Ch 32 at 79 per Diplock LJ 'it is 350 years and a civil war too late for the Queen's courts to broaden the prerogative.'

${ }_{28}^{28}$ Ibid, para 369 'The general rule is that prerogatives cannot be affected or parted with by the Crown, except by express statutory authority. However, prerogatives connected with the royal revenues, such as waifs, estrays and the like may be granted out in the form of franchises in certain cases. Some of the prerogatives relating to public government and the right of pardoning offences are usually delegated to the governors.' Prerogatives which cannot be delegated include the powers of making an alien or denizen, pardoning felonies etc. See Bacon, $\mathrm{n} 6$, vol 5, p 579.

29 Ibid, para 370.

${ }^{30}$ Halsbury, n 1, para 371 classifies the special privileges enjoyed by the sovereign by virtue of the prerogative under 3 heads, those concerned with: (a) the special qualities of pre-eminence and dignity ascribed to the sovereign in her regal capacity; (b) the various powers 
easiest to analyse them into 'major' and 'minor' prerogatives. Major Crown prerogatives which are still extant comprise the following, the prerogative of the Crown to:

(a) Make war - and peace;

(b) Control the armed forces;

(c) Issue proclamations;

(d) Make, and ratify, treaties;

(e) Grant peerages, honours and exercise patronage;

(f) Conduct diplomacy;

(g) Govern British overseas territories;

(h) Interact with Parliament;

(i) Appoint, and remove, ministers;

(j) Appoint judges as well as other judicial matters (including the grant of pardons)

(k) Grant, and revoke, passports;

(1) Organise the civil service;

(m) Exercise emergency powers. ${ }^{31}$

There are, then, a host of 'minor' Crown prerogatives, a large majority of which are obsolete. These can be categorised into those which were intended to:

- Raise money for the Crown by way of tax or toll; ${ }^{32}$

- Reflect the sovereign's pre-eminence ${ }^{33}$ - including in respect of Crown grants; ${ }^{34}$

- Favour retainers for their support; ${ }^{35}$

- Military prerogatives; ${ }^{36}$

- Corporate prerogatives. $^{37}$

Given that a number of minor prerogatives flow from the major ones, in this article I will juxtapose the same, where possible. The first Crown prerogative to consider - and whether it is obsolete or should be transferred to

and authorities entrusted to the sovereign as the supreme executive officer in the State and exercised in fact by the ministers of the Crown; (c) the special privileges enjoyed by the sovereign in relation to rights in property which have been allowed to her for the support of the royal dignity and the increase of the royal revenues. However, this classification is too general to be of much help. Blackstone, $\mathrm{n} 8$, vol 1 , $\mathrm{p} 233$ also had a threefold classification 'These substantive or direct prerogatives may again be divided into three kinds: being such as regard, first, the king's royal character; secondly, his royal authority; and, lastly, his royal income.' Cf. Chalmers \& Asquith, n 12, pp 148-9 (those regarding the royal: (a) character; (b) authority; (c) revenue).

31 See generally, Halsbury, n 1, paras 801-87 and HC, n 3, pp 8-9. Cf. Maitland's classification, n 13, p 422, much of which is statutory now.

32 The way the sovereign did this was by way of seeking to impose national taxes under a variety of names (tax, tallage, aid, benevolence, loan, forced loan, mise etc) as well as franchising tolls. The sovereign also raised money from his right to: (a) royal mines; (b) waifs; (c) estrays; (d) levy tolls; (e) wreck (also, flotsam, jetsam and ligan); (f) treasure trove (also, the right to dig for the same), (g) establish markets; (h) establish fairs; (i) establish ferries. All of these - except for (a) - have been frequently franchised. In the past the sovereign also franchised royal forests; free chases (the right to hunt, and kill, game in a certain area), free warrens (places privileged for the keeping of beasts and fowls of warren) and free parks (enclosed chases extending over a man's own land). These franchises were abolished by the Wild Creatures and Forest Laws Act 1971 - save in relation to mute swans in open water (see n 33 below).

33 Because the sovereign was treated as superior to common people he was granted the right to: (a) royal fish; (b) mute swans in open waters. Both these were franchised. The sovereign was also entitled to use: (c) a great seal; and (d) execute by way of sign manual. Rules governed (and still govern) the use of the same. The sovereign was also, by reason of his superiority, (e) exempt in respect of his personal property in respect of : wreck, estrays, waifs, customary rates (and tolls) and distress; (f) exempt from the enforcement of a pledge (or lien) or a debt in execution; (g) given priority in the case of the joint ownership of goods and debts. For the attribute of pre-eminence, see Blackstone, $\mathrm{n} 8$, vol 1, pp 234-5.

34 viz. (a) Crown grants are construed most favourable to the Crown (including presumptions in respect of deceit and mistake); (b) certain prerogatives with respect to reserving rents - and the levying of distress - in respect of Crown grants; (c) a prerogative - in respect of Crown leases - to re-enter on default without having to make prior demand on the lessee; (d) the presumption of a Crown grant; (e) the Crown is not bound to offer an acquittance (or receipt) on the discharge of a debt; ( $\mathrm{f}$ ) the Crown is not bound by legal fictions; ( $\mathrm{g}$ ) the Crown is not bound by estoppel by deed. However, the Crown is prohibited from making certain forms of grant.

${ }^{35}$ The Crown favoured retainers by granting to them: (a) counties palatine (those of Chester, Durham and Lancaster still exist); (b) duchies (those of Lancaster and Cornwall still exist); (c) grand sarjeanties; (d) petty sarjeanties; (e) honours.

${ }^{36}$ Crown prerogatives to: (a) impress subjects for the navy; (b) issue letters of reprisal and marque; (c) issue letters of safe conduct; (d) prohibit subjects from leaving the realm; (e) order subjects to return to the realm; (f) dig for saltpetre (for gunpowder).

${ }^{37}$ Crown prerogatives to: (a) create counties corporate and confer the status of a: (i) borough; (ii) royal borough; (iii) royal county; (iv) royal town; (v) city. Also, (b) to create corporations. 
Parliament - is the prerogative of the Crown to establish common law courts. Also, some other minor judicial prerogatives of the sovereign in person.

\section{Prerogative - To Establish Common Law Courts}

From the Norman Conquest of 1066 - at least - the sovereign has been the fons et origo of many institutions of Government. Halsbury notes that, presently:

The monarch is Head of State, and the supreme executive officer in the state; she is the titular head of the Church of England, the law, the navy, the army and the air force, and the source of justice and all titles of honour, distinctions and dignities; foreign affairs are conducted, declarations of war and peace made, and the law executed and administered, solely in her name, although the monarch acts in such matters only on the advice of her ministers. ${ }^{38}$ (italics supplied)

\section{(a) Prerogative - Common Law Courts}

As to the power of the sovereign to establish courts, Halsbury states:

As the source and fountain of justice the Crown may issue such commissions to administer the law as are warranted by the common or statute law; ${ }^{39}$ but may not, without statutory authority, establish courts to administer any but the common law, ${ }^{40}$ and [the Crown] may not, it is said, grant the right to hold a court of equity. ${ }^{41}$ (italics supplied)

One of the authorities cited for this Crown prerogative is Re Lord Bishop of Natal (1865) in which Lord Chelmsford LC stated:

It is a settled constitutional principle or rule of law, that although the Crown may by its prerogative establish courts to proceed according to the common law, yet it cannot create any new court to administer any other law; and it is laid down by Lord Coke in the $4^{\text {th }}$ Institute [published in 1641 ] that the erection of a new court with a new jurisdiction cannot be without an Act of Parliament. ${ }^{42}$

The Crown prerogative to establish courts (along with its control of the military) is probably one of the oldest Crown prerogatives and it pre-dates the Norman Conquest. Such Anglo-Saxon courts were, of necessity, common law courts since equity had not yet developed; nor had legislation specified the same.

\footnotetext{
${ }^{38}$ Halsbury, n 1, para 14. Also, para 351 'In law the monarchy remains legally central to the powers of government. Such powers may be formally vested in the monarch (or the sovereign) or, latterly, the Crown. The monarch's personal functions in the actual administration of the executive are now restricted principally to attaching her signature to various executive documents, the nature and general policy of which have been previously determined by ministers either individually or collectively. In discharging her legal functions the monarch is bound by constitutional conventions which minimise the scope of her discretion.'

${ }^{39}$ Comyns, n 6, Prerogative, D 29 'The king may grant such commissions as are warranted, or allowed, by the common law, or by act of parliament. Commissions are general, as to persons, crimes etc as a general commission of oyer and terminer. [now obsolete]. Or special, when confined to particular persons, offence, or place... But the king cannot grant a commission not usual, nor allowed by act of parliament.'

${ }^{40}$ Ibid, D 28 'The king, by his prerogative, may make what courts for the administration of the common law, and in what places, he pleases. But the king cannot erect a court of chancery, or conscience; for the common law is the inheritance of the subject...So, the erection of a new court, with a new jurisdiction, cannot be without an act of parliament. And if it be erected, the jurisdiction ought to be expressed; for nothing omitted shall be within such jurisdiction. So the king cannot grant to a court, that it may proceed according to the civil law. Nor can, [the king] by charter or commission etc alter the common law.' Coke, $\mathrm{n}$ 7, vol 4, $\mathrm{p} 86$ 'In a premunire between John Perrot plaintiff, and TMHW and others defendants, [26 \& 27 Eliz, i.e. 1584] it was resolved by Sir Christopher Wray chief justice, and the court of king's bench, that the queen [Elizabeth I, 1558-1603] could not raise a court of equity by her letters patents, and that there could be no court of equity but by act of parliament, or by prescription time out of mind of man'. See also pp 213, 242. See also Rolle, n 5, vol 2, p 164, line 25.

${ }^{41}$ Bacon, n 6, vol 5, p 579, Prerogative F1 'The king cannot grant to any to hold a court of equity, because this is in derogation of the common law, and the chancery in Chester and Durham are incidents to a county palatine which had jura regalia.' [the chancery courts of Chester and Durham no longer exist, see Halsbury, n 1, para 307]. See also W Forsyth, Cases and Opinions on Constitutional Law (London, Stevens \& Haynes, 1869), pp 169-72 (Opinion of the Attorney General and Solicitor General in 1738 on the erection of a Court of Exchequer in the Colonies, Opinion of the Attorney General in 1749 on the king's power to erect Courts of Justice in Newfoundland, Opinion of the Attorney General in 1750 that the sovereign could not grant power to establish a Criminal Court in Newfoundland but under the Great Seal). See, in particular, pp 186-7.

423 Moo PCCNS 115 (16 ER 43). Heuston, n 11, p 68 'she [the Queen] may not establish courts to administer any but the common law and if she does so she may find that Parliament refuses to provide funds necessary to pay the stipends of any judges whom she may appoint.' Bradley, n 1, p 249 'The Crown can no longer by the prerogative create courts to administer any system of law other than the common law. See also Sunkin, n 12, p 345. Hale, n 10, p 183 'He [the king] cannot erect an arbitrary judicatory or court of equity' Also, p 184. See also Holdsworth, n 9, vol 10, pp 360, 414 (the Crown can erect only courts which possess a common law jurisdiction) and Amos, n 12 , p 117.
} 
- In Anglo-Saxon times there were - at least - courts of the shire and hundred. ${ }^{43}$ These must, both in theory and practice, have emanated as a result of the exercise of royal (Crown) power, even though there was then no jurisprudential analysis of this, as such;

- There were, also, from Anglo-Saxon times many private jurisdictions or privileged areas (sokes) which were granted by the sovereign to ecclesiastics and powerful retainers. These, invariably, had the privilege of 'sac and $s o c$ ', that is, a franchise to administer their own 'private' courts. These courts comprised those exercising a criminal function - courts leet ${ }^{44}$ - as well as courts which dealt with civil matters. The latter tended to be manorial courts - such as those for free tenants (court baron), ${ }^{45}$ for villeins or bondsmen (court customary) and for tenants of the royal demesne (court of ancient demesne).

From Norman times, the royal courts of common bench, chancery and exchequer emerged - without prejudice to the existing 'common law' courts of the shire and hundred as well as court leets and manorial courts.

- However, with the increasing power of the Crown, royal courts began to assume greater and greater prominence while franchised courts diminished. Indeed, by the $16^{\text {th }}$ century, many of the latter were effectively obsolete;

- Along with the main royal courts, grew up a plethora of small courts handling a variety of matters. ${ }^{46}$

Legal analysis of the Crown prerogative also commenced. This included the prerogative to establish common law courts, but not those dispensing equity. ${ }^{47}$

\section{(b) Establishing Courts - Present Position}

Today, the principal courts comprising English court system derive from legislation. In descending order, these comprise the:

(a) Supreme Court (also, the Judicial Committee of the Privy Council);

(b) Court of Appeal (also, the Courts Martial Court of Appeal);

(c) High Court;

(d) Crown Court;

(e) County courts;

(f) Magistrates' courts. ${ }^{48}$

As noted, these statutorily created courts do not exist by virtue of the Crown's prerogative to establish common law courts. Further, the Crown would not exercise this prerogative today since it can only create common law courts and - from Victorian times - all courts administer both the common law and equity. As a result, this Crown prerogative is obsolete and should be abolished: ${ }^{49}$

\footnotetext{
${ }^{43}$ Chrimes, n 13, p 80 'long before the Norman Conquest, the Crown had learnt to use the shire and the shire court, the hundred and the hundred court, and the still smaller unit of the vill (roughly the village community) for many purposes of government, law-enforcement, and justice.' See also Stubbs, n 13, vol 1, pp 114, 121. The hundred court was also known as the hundred-gemot or wapentake court. It generally met monthly and its criminal jurisdiction was perpetuated in the court leet (see $\mathrm{n} 44$ below).

${ }_{44}$ Also called the view of frankpledge (or lay day) the court leet was a court of record. It exercised criminal jurisdiction in respect of less serious crimes such as infractions of food and drink laws and agricultural matters, with a trial before a jury. Meetings of the court were often annual and petitions were brought before it by means of a 'presentment' by an individual or the jury itself. The steward of the manor acted as judge. See GS McBain, Abolishing Various Obsolete Courts (2012) Coventry LJ, vol 17, no 1.

${ }_{45}$ Some manors - being of great size - were termed an 'honour' or 'honor'. For example, the duchy of Lancaster was originally an honour, prior to this becoming sub-sumed into the greater title of 'duchy'.

${ }_{46}$ For those still in existence, see McBain, $\mathrm{n} 44$. For those in existence in the time of Lord Coke, see Coke, $\mathrm{n} 7$, vol 4.

${ }^{47}$ One of the early statements on the Crown having the prerogative to establish common law courts, but not those of equity, is that of Coke, see $\mathrm{n} 40$ (in 1641).

${ }^{48}$ See generally, Halsbury, n 1, para 301 et seq. Blackstone, n 8, vol 1, p 257 (writing in 1765) stated 'all jurisdictions of courts are either mediately or immediately derived from the crown'. This is no longer true and it fails to refer to common law courts in any case.

${ }_{49}$ Phillips, n 12, p 418 'The prerogative power to create courts is now virtually useless, because, first (if Coke was right), such courts could not administer equity or any other system except the common law; and secondly, the expense of maintaining such courts would require Parliamentary authority.' Sunkin, n 12, p 347 'Is it at all likely that the Crown rather than Parliament would set up any new court - let alone one which could only administer the common law?' For Victorian legislation providing that the High Court rules of law and equity should be administered concurrently, see Holdsworth, n 9, vol 2, p 640. See also Chalmers \& Asquith, n 12, pp 156-7.
} 
- It is also important today - given the need for the strict impartiality of judges and the administration of the law - that Parliament alone create any new courts, not least, to prevent overlap and competing jurisdiction;

- Past attempts by the Crown, in post medieval times, to create courts ended - in some instances - in their being unsuccessful judicially as well as their being loathed. An example is the Court of Star Chamber (abolished in 1641). ${ }^{50}$

In the present English legal system there also exist various (peripheral) courts other than those stated above. Thus,

- Courts leet and courts baron still exist in the English legal system. However, with limited exceptions, they no longer operate; ${ }^{51}$

- The old forest courts of the verderers of the New Forest and the Forest of Dean also exist. ${ }^{52}$

To the extent these peripheral courts comprise common law courts, they would not be affected if the Crown's prerogative to establish common law courts were abolished, since it would not be retrospective. In any case, it has been asserted in previous articles that all these peripheral courts are obsolete. ${ }^{53}$

In conclusion, the Crown prerogative to establish common law courts should be abolished. ${ }^{54}$ It does not apply to the principal English courts today, which have been established by legislation. In any case, the Crown would not establish a common law court, today, without combining it with equity. Abolition of this prerogative would effect no change in practice. However, it would clarify the law and remove an obsolete prerogative.

\section{Prerogative - Sovereign and Her Courts}

\section{(a) Judicial Capacity - Restrictions}

Along with the abolition of the Crown prerogative to establish common law courts, the relationship between the sovereign and her courts should be reviewed.

- In ancient times, the sovereign may have sat as a judge in his courts and dispensed judgment. ${ }^{55}$ Ehrlich cites instances in the reign of Henry III (1216-72). ${ }^{56}$ However, later commentators were not so sure that the sovereign ever sat a judge, as opposed to attending court as a visitor; ${ }^{57}$

- What is clear is that the sovereign did administer justice in person on the battlefield (according to martial law). ${ }^{58} \mathrm{He}$ also delivered judgment in a few criminal trials 'on the record.' Thus, Edward III $(1327-77)$ condemned various persons as traitors (it seems) on the basis of his own testimony. ${ }^{59}$

\footnotetext{
${ }^{50}$ The court of Star Chamber was regulated by the Act pro Camera Stellata 1487. However, it existed prior to that, emanating - originally from the royal council of Edward III (1327-77) which sometimes sat in the Star Chamber. See also Tanner, n 13, pp 18-9. Also, Keir \& Lawson, n 12, p 96 'The rule precludes the establishment of prerogative courts capable of developing a system of law in conflict with the common law, such as Star Chamber was.' See also T Bingham, The Rule of Law (Penguin, 2010), p 16.

${ }^{51}$ See McBain, $\mathrm{n} 44$.

${ }_{53}$ GS McBain, Abolishing some more Obsolete Crown Prerogatives: Part 2(2011) Liverpool LR (Dec 2011, online), pp 293-8.

53 See McBain, ns 44 \& 52 .

${ }^{54}$ This would not prevent the Crown from establishing a body to administer a scheme for conferring financial benefits on individuals. $R v$ Criminal Injuries Compensation Board ex p Lain [1967] 2 QB 864, 867, See also Bradley, n 1, p 249. Also, $R$ v Home Secretary ex $p$ Harrison [1988] 3 AE 86.

${ }_{55}$ Blackstone, n 8, vol 1, p 257 'It is probable, and almost certain, that in very early times, before our constitution arrived at its full perfection, our kings in person often heard and determined causes between party and party.' Phillips, n 12, p 417 'Instances are recorded of Plantagenet kings personally dealing with criminal cases, and Edward IV [1461-70 and 1471-83] sat with the judges for three days to see how they did their work.' See also Chitty, n 10, p 75; Hale, n 10, pp 179, 182; FM Nichols, Britton (John Byrne \& Co, 1901), p 2 and Bracton, n 22, vol 2, p 304. See also BC Keeney, Judgment by Peers (Harvard UP, 1949), p 39. Also, the position in Spain after 1247 , p 31. See also Chalmers \& Asquith, n 12, pp 154-5.

${ }^{56}$ L Ehrlich, Proceedings against the Crown. (1921) 6 Oxford Studies in Social and Legal History (ed P Vinogradoff), ch 1, especially pp 17, 34-8. See also Allen, n 11, p 93 and Viner, n 6, vol 16, p 536. See also M Paris, English History (trans JA Giles, London, Henry G Bohn, 1852), vol 1, p 139 (in 1238 Henry III ordering an attempted assassin to be pulled apart by horses), p 316 (in 1244, he ordered French with property in England to be disseised).

${ }_{57}$ Prohibitions del Roy (1607) 12 Co Rep 63 (77 ER 1342) p 64, 'the judges informed the king, that no king after the Conquest [i.e. after 1066 assumed to himself to give any judgment in any cause whatsoever, which concerned the administration of justice within his realm, but these were solely determined in the courts of justice.' W Hawkins, A Treatise of the Pleas of the Crown (printed by E \& R Nutt \& R Gosling, In the Savoy, 3rd ed, 1739), vol 2, p 2, s 2 'where it is said in some of our ancient histories, that our kings have sometimes sat in person with the justices at the arraignment of great offenders, probably it ought not to be intended that they came as judges, but as spectators only, for the greater solemnity of the proceeding.'

${ }_{58}$ This military (martial) justice exercised in person by the sovereign was later exercised through his commander-in-chief - the Earl Marshall
} 
Obviously, this form of 'personal' royal justice was capable of gross mis-use and - over the centuries - caselaw has restricted its ambit. In particular, in the time of James I (1603-25), caselaw restricted this power of the sovereign to act in person in legal matters.

- Power of Arrest. In a Yearbook case in 1485, Huse CJKB noted that the sovereign could not, himself, effect an arrest. ${ }^{60}$ Today, the Justice of the Peace Act $1968 \mathrm{~s} 1$ (7) provides that any power to commit to prison (or to issue warrants of arrest or search warrants) which may have been exercisable at common law by the sovereign in person, is abolished; ${ }^{61}$

- Sitting as a Judge. The case of Prohibitions del Roy $(1607)^{62}$ confirmed the sovereign could not sit as a judge in the royal courts, ${ }^{63}$

- Withdrawing Cases from the Court. The case of Brownlow v Cox \& Michil (1615) held that the sovereign could not withdraw matters of State from the cognizance of the courts; ${ }^{64}$

- Ability of Sovereign to Delay Justice. In the case of Commendams (1616) ${ }^{65}$ James I (1603-25), pursuant to an asserted Crown prerogative, directed the Attorney-General (Francis Bacon) to write to Coke $\mathrm{CJ}$ requesting (commanding) that the judges delay their decision until the king had spoken with them. A joint letter was sent by the judges in reply, indicating that their oath forbade them to delay justice. However, after attending an audience with the sovereign, the majority reversed their opinion, with the exception of Coke. ${ }^{66}$

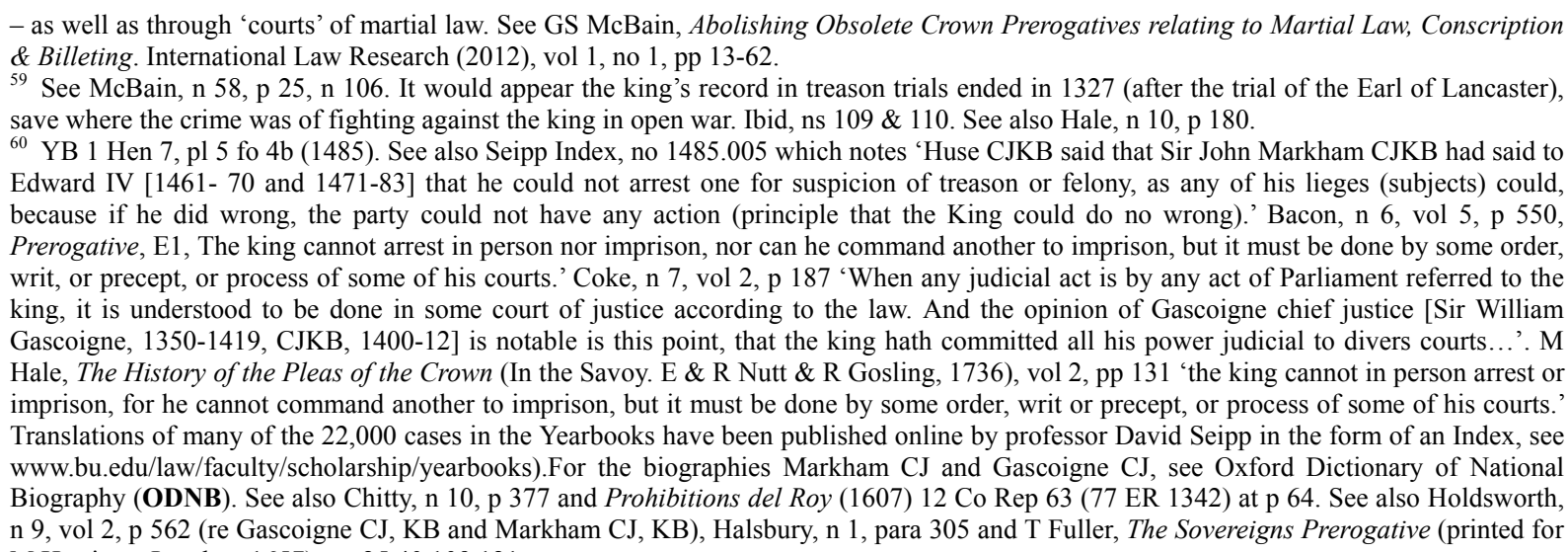
n 9, vol 2, p 562 (re Gascoigne CJ, KB and Mark

${ }_{61}$ Halsbury, n 1, paras 6, n 10 \& 375. For abuses in the time of Elizabeth I (1558-1603) and Charles I (1625-49) see Taswell-Langmead, n 13, pp 308-9, 367, 371, 397-8. For detention of a person under a privy council warrant on the special command of the sovereign (per speciale mandatum domini regis), see Darnel's Case (1627) 3 ST 1. See also Holdsworth, n 9, vol 6, pp 32-4.

${ }_{62} 12$ Co Rep 63 ( 77 ER 1342) at p 64 'the king in his own person cannot adjudge any case...but this ought to be determined and adjudged in some court of justice, according to the law and custom of England.' Halsbury, n 1, para 305 'James I (1603-25) is said to have endeavoured to revive the ancient practice of sitting in court, but was informed by the judges that he could not deliver an opinion.' See also Coke, n 7, vol 2, p 187; Holdsworth, n 9, vol 10, 415; Halsbury, n 1, para 7, n 3 and Heuston, n 11, p 32.

${ }_{63}$ See also Hale, $\mathrm{n}$ 60, vol 2, p 282. Hawkins, $\mathrm{n} 57$, vol 2, c 1, p 2 'the king himself cannot sit in judgment upon any indictment, because he is one of the parties to the suit.' HJ Stephen, New Commentaries on the Laws of England (Butterworth, 1844), vol 2, pp 526-7 'he cannot personally distribute justice.' See also Sunkin, n 12, p 198.

643 Bulst 32 (81 ER 27) (Also, 1 Rolle 288, 81 ER 498). Prohibitions del Roy (1607) 12 Co Rep 63 (77 ER 1342) at p 64 'the king cannot take any cause out of any of his courts, and give judgment upon it himself.' Dicey, n 11, p 371 referred to 'Bacon's [when Attorney-General] attempt to prevent the judges by means of the writ De non Procedendo Rege Inconsulto from proceeding with any case in which the interests of the Crown were concerned.' Chitty, n 10, p 76 'the king cannot, legally, authorise any court to proceed contrary to the English laws, or by any other rule.' See also Ridges, n 13, pp 191-2 and SR Gardiner, History of England from the Accession of James I to the outbreak of the Civil War 1603-1642 (London, Longmans, 1883), vol 3, 7ff. Also, Keir \& Lawson, n 12, p 96; Holdsworth, n 9, vol 2, pp 254 \& $562-3$ and F Hargrave, Collectanea Juridica (1791-2), vol 1, p 168 (argument of Bacon when Attorney-General on the writ De Rege Inconsulto). Holdsworth, $\mathrm{n} 9$, vol 10, p 345 'the power of the king to stop an action by the issue of the writ rege inconsulto was, in effect, put an end to by Coke's decision against the prerogative.' See also Halsbury, para $6, \mathrm{n} 10$.

${ }_{65}$ Reported as Colt and Glover v Bishop of Coventry Hob 140 (80 ER 290). A commendam is a papal (later, royal) permission allowing a bishop to hold a benefice at the same time as his bishopric. See also Gardiner, n 64, vol 3, pp 13-9 and Tanner, n 13, pp 39-40. For early legislation which sought to prevent the sovereign from delaying a cause - or withdrawing it from the courts by writs issued under the lesser or privy seal - see Anson, n 11, vol 2, pt 1, p 34. See also Hargrave, n 64, vol 1, pp 1-19. See also Lord Hewart, The New Despotism (London, Ernest Benn, 1929), pp 111-3.

${ }_{66}$ James I asked 11 judges one by one "whether if at any time in a case depending before the judges which his majesty conceived to concern him either in power or profit, and thereupon required to consult with them, and that they should stay proceedings in the meantime, - they ought not to stay accordingly?' Tanner, n 13, p 40 'Eleven of the judges answered in the affirmative; Coke alone replied that when that case should be, he would do that [which] should be fit for a judge to do'. See also The Letters and Life of Francis Bacon (London, Longmans, 1868), vol 5, pp 357-69 and Hale, n 10, pp 194-6. See also Prohibitions del Roy (1607) 12 Co Rep 63 (77 ER 1342) at p 64 'it appears by the Act of Parliament [Statute of Northampton] of 2 Ed 3 c 9 [1328, rep] 2 Edw 3 cap 1[1328, rep], that neither by the great seal, nor by the little 
These restrictions on the sovereign were re-inforced by the proposition enunciated in the Case of Proclamations (1611) that the Crown prerogative was circumscribed by the common law and Parliament. ${ }^{67}$ Such restrictions are so long established that - today - the sovereign would not seek to circumvent them. However, it is asserted that - as with the abolition by statute of the power of the sovereign to order an arrest - these possible Crown prerogatives should be formally abolished by legislation, to clarify the position. ${ }^{68}$

In conclusion, any prerogative of the sovereign to sit as a judge - or to withdraw any matter of State from the courts or to request any judge to delay giving judgment - should be abolished.

\section{(b) Sovereign - Choice of Court}

The sovereign - in person - retains the right to sue in whatever court she pleases. Halsbury states:

The Crown might in general choose its own forum and sue in what court it pleased, and in this respect the monarch in her private capacity has the former attributes of the Crown. ${ }^{69}$

In respect of this, in Willion $v$ Berkeley $(1561),{ }^{70}$ it was stated:

the statute of Magna Carta, cap 11, which says common pleas shall not follow our court, does not bind the king, but he may sue in the king's bench for his debt, or in other common pleas in which he is plaintiff. $^{71}$

Today, this freedom of the Crown to choose what court it wants to sue in, is obsolete. Further, it is no longer required.

- It is obsolete since Magna Carta, chapter 11, has been repealed (since 1879) and the courts of Common Pleas and Exchequer no longer exist. They were merged with the King's Bench in 1881 into the King's Bench division and the latter is very different (both in structure and the cases it handles) to what it was both prior to the Victorian reforms of 1875 and when this prerogative of choice of court was first enunciated;

- Further, the freedom of the Crown to select the court in which it wishes to proceed can affect the impartiality of the judgment for the Crown might then choose a court (or judge) more pre-disposed to its interest. Thus, this prerogative has considerable potential for abuse.

In conclusion, it is asserted that this prerogative of the sovereign to select the court should be abolished. It is no longer utilised in practice and it is not necessary. Also, its implementation could result in injustice.

\section{(c) Sovereign - Court Procedure}

\footnotetext{
seal, justice shall be delayed.' Holdsworth, n 9, vol 2, p 561 refers to an attempt in 1344 of Edward III (1327-77) to interfere with the hearing of a case of quare impedit by letters under his privy seal.

${ }^{67} 12$ Co Rep 74 (77 ER 1354) at p 76 'it was resolved, that the king hath no prerogative, but that which the law of the land allows him.' See also Sunkin, n 12, p 198.

${ }^{68}$ i.e. 'Any Crown prerogative entitling the sovereign in person to : (a) sit as a judge in any court; (b) withdraw any matter of State from the jurisdiction of any court; (c) delay the giving of any judgment, is abolished.'

${ }^{69}$ Halsbury, n 1, para 391. Coke, n 7, vol 4, p 17. Chitty, n 10, p 244 'the king has the undoubted privilege of suing in any court he pleases...The Crown possesses also the power of causing suits in other courts to be removed into the Court of Exchequer...It seems, also, that where a mere equitable question is raised, chancery is the better forum to entertain it, though the king be interested.' H Finch, $A$ Description of the Common Laws of England (first published as Nomotexnia, this ed 1759), p 161 'The King may sue in any of the courts that he will, that is, he may have a quare impedit...or a writ of escheat...returnable in the king's bench, or a quiere incumbravit, there, although the record of the recovery be in the common pleas.' See also Viner, n 6, vol 16, p 572 'The King has a prerogative of suing in what court he pleases.'

701 Plowd 223 (75 ER 339).

${ }^{71}$ At p 240. Magna Carta, c 11 (1297 version, repealed in 1879) stated 'Common pleas shall not follow our court, but shall be holden in some place certain.' Coke, n 7, vol 2, p 21 'Before this statute, common pleas might have been holden in the kings bench, and all original writs returnable in the same bench: and because the court was holden coram rege, and followed the kings court, and removable at the kings will, the returns were ubicunque fuerimus etc whereupon many discontinuances ensued, and great trouble of jurors, charges of parties, and delay of justice, for these causes this statute was made.' Also, 'The king may sue any action for any common plea in the kings bench, for the general act [i.e., chapter 11] does not extend to the king.' (spelling modernised). See also 16 Edw 4 pl 4 (1474), Seipp Index no 1474.008(see n 60, Index) (Exchequer Chamber) which records Billyng CJKB, Nedeham JKB and Yonge JKB as stating 'as the king is above all persons in dignity and honour above, so he (the king) is in law in prerogative, and the law is understood (pris) and construed favourably for him (the king); because he (the king) can sue in whatever court he pleases.' See also WS McKechnie, Magna Carta (Glasgow, James Maclehose \& \& Sons, 1914), pp 261-9.
} 
The sovereign may resort to particular forms of court procedure. Halsbury states:

Special modes of redress against the subject by means of information, inquisitions or inquests of office, extents, scire facias, quo warranto and mandamus were provided by law, and still remain in relation to the monarch in her private capacity as far as they are appropriate. ${ }^{72}$ The monarch may waive these prerogative remedies and resort to the usual forms of action ${ }^{73}$ unless they are inconsistent with the royal dignity. ${ }^{74}$

Today, there is no need for the sovereign to have personal forms of court procedure, most of which are obsolete in any case.

It is asserted this prerogative enabling the sovereign to use a special procedure should be abolished.

\section{(d) $\underline{\text { Sovereign }- \text { Costs }}$}

There is a common law rule that the sovereign (or any person acting for her) does not have to pay - or receive costs. Halsbury notes:

The common law rule that neither the monarch, nor any person suing to her use, pays or receives costs ${ }^{75}$ now survives only in relation to proceedings affecting the monarch in her private capacity, ${ }^{76}$ and in civil proceedings, including arbitrations, costs are in the discretion of the court. ${ }^{77}$

It is asserted this rule is also otiose; it should be abolished and the general principles of law as to costs should apply to the sovereign in respect of her personal legal business, just as it does to everyone else.

In conclusion, it is asserted that any prerogative of the sovereign to: (a) sit as a judge; (b) withdraw any matter of State from the cognisance of any court; (c) request any judge to delay giving judgment; (d) sue in whatever court she pleases; should be abolished. Also, any common law rule as to costs affecting the sovereign in a personal capacity.

\section{Sovereign Can Do No Wrong}

There has long existed a legal fiction (apophthegm) that the sovereign can do no wrong. ${ }^{78}$ When this first arose is unclear. Anson thought it was when Henry III (1216-72) reigned, when still a child, ${ }^{79}$ and Ehrlich cites instances of sovereigns prior to Henry III being held liable in court for dissesin. ${ }^{80}$

\footnotetext{
${ }^{72}$ Latin and English informations, writs of extent and writs of scire facias were abolished by Crown Proceedings Act 1947, s 13, sch 1 except in relation to proceedings by or against her Majesty in her private capacity and subject to certain other exceptions which including proceedings on the Crown side of the Queen's Bench division and proceedings by the Crown otherwise than in right of HM Government in the UK, ss 23, 40(1), 2(c). Informations in the nature of quo warranto were abolished by the Administration of Justice (Miscellaneous Provisions) Act 1938, s 9 (rep). See also Crown Proceedings Act 1947, s 40(1).

${ }^{73}$ Chitty, n 10, p 244 'The modes of redress which the Crown may adopt against a subject are - 1st, by the usual common law actions; 2 , by Inquisition, or Inquest of Office, and under this head, we will consider extents in chief and in aid, and the writ of diem clausit extremum; 3 , by scire facias, to repeal grants etc; 4 , by information of intrusion or debt and in rem; 5 , by quo warranto; 6 , by mandamus ...The general rule is, that the King may waive his prerogative remedies, and adopt such as are assigned to his subjects... The only exception seems to be in the case of actions, which suppose an eviction or disseisin, as an assize, or, it seems, an action of ejectment. The king cannot maintain such actions, they being inconsistent with his royal dignity, and contradictory to the fiction of law, that the king cannot be dispossessed of property once vested in him. 'As to this exception in respect of dissesin, it is most unlikely to apply in modern times to the sovereign in person.

${ }_{74}^{7}$ Halsbury, n 1, para 391. For a description of these forms of procedure see Holdsworth, n 9, vol 10, pp 343-5.

${ }^{75}$ Blackstone, n 8, vol 1, p 233 'no costs shall be recovered against the king.' Bowyer, n 11, p 188 'no costs can be recovered against her [the Queen] in any court'. Johnson v R [1904] AC 817 at 824 per Lord Macnaghten 'their Lordships are of opinion that, in dealing with costs in cases between the Crown and a subject, this Board ought to adhere to the practice of the House of Lords, and that in future the rule should be that the Crown neither pays nor receives costs unless the case is governed by some local statute, or there are exceptional circumstances justifying a departure from the ordinary rule.'

${ }_{76}$ Administration of Justice (Miscellaneous Provisions) Act 1933, ss 7 (costs in Crown proceedings) and 9 (sovereign in a private capacity).

${ }_{77}^{77}$ Halsbury, n 1, para 392.

${ }^{78}$ Blackstone, n 8, vol 1, p 237 'a maxim...that the king himself can do no wrong; since it would be a great weakness and absurdity in any system of positive law, to define any possible wrong, without any possible redress.' Bacon, n 6, vol 5, p 550 'From the dignity of his office and person the law presumes him incapable of doing any wrong.' King's Prerogative in Saltpetre (1606) 12 Co Rep 12 (77 ER 1294$)$ at p 12 'the king (it is said in our books) cannot do any wrong.' See also De Smith \& Brazier, n 13, pp 140-1.

${ }^{79}$ Anson, n 11, vol 2, p 20. Allen, n 11, p 95 'Before the reign of Edward I [1272-1307] the king of England might have been sued as a common person.' Also, Comyns, n 6, vol, p 212, Action, c 1 . Cf. Staunford, n 10, p 42 (published 1607) 'I think the law was never so that a man should have any such action against the king.' (spelling modernised). Maitland, n 12, p 100 'there was no legal procedure whereby the king could either be punished or compelled to make redress.' Bacon (when Attorney-General in the time of James I (1603-25)) in argument at
} 
- It is sometimes asserted that Bracton (writing c.1240) endorsed - or propagated - this legal fiction, since he said that a writ could not be issued against the sovereign, ${ }^{81}$

- However, Bracton clearly noted that the king could do wrong. He also noted that an injured party could petition him to remedy his wrong. ${ }^{82}$ Thus, moral pressure could be brought to bear on the sovereign even if not legal pressure.

This legal fiction that the king can do no wrong is capable of mis-interpretation, as Chitty noted (in 1820):

It was pretended by some that it meant that every measure of the king was lawful, a doctrine subversive of all the principles of which the constitution is compounded. It is a fundamental general rule, that the king cannot sanction any act forbidden by law. ${ }^{83}$

Indeed, this legal fiction is better re-stated as one that the sovereign is immune from prosecution. That is, he cannot be sued in his own courts. ${ }^{84}$ Blackstone, writing in 1765, stated:

Besides the attribute of sovereignty, the law also ascribes to the King, in his political capacity, absolute perfection. The King can do no wrong. Which ancient and fundamental maxim is not to be understood, as if everything transacted by the government was of course just and lawful, but means only two things.

First, that whatever is exceptionable in the conduct of public affairs is not to be imputed to the king, nor is he answerable for it personally to his people: for this doctrine would totally destroy that constitutional independence of the crown, which is necessary for the balance of power, in our free and active, and therefore compounded, constitution. And, secondly, it means that the prerogative of the crown extends not to do any injury: it is created for the benefit of the people, and therefore cannot be exerted to their prejudice. ${ }^{85}$ (wording divided for ease of reference)

These arguments of Blackstone are not of great merit in that they do not justify - as such - why the sovereign is immune from prosecution. ${ }^{86}$ One would suggest the rationale for this legal fiction arose from an amalgam of various underlying ideas and purposes: ${ }^{87}$

bar argued the sovereign could not be joined as a party but could be petitioned in chancery. See Brownloe v Michell (1615) 1 Rolle 288 (81 ER 498) at $\mathrm{p} 290$. For this in Victorian times see Sunkin, n 12, ch 9 (legal remedies against the Crown and its officers). Allen (writing in 1849), n 11, p 93 'The king of England cannot be sued in a court of law; but if any one has demand upon him in point of property, the plaintiff has only to petition him for redress in his courts of chancery or exchequer, and on having the attorney-general's fiat, which ought to be given of course, he will have justice administered to him with as much certainty and despatch as if he had brought an action against a subject. The plaintiff indeed will be told, that he receives justice from the king as a matter of grace and not on compulsion, and he must pray for it and accept in on these terms.' See also Keith, n 13, p 57 and Chalmers \& Asquith, n 12, pp 150-1.

${ }^{80}$ Ehrlich, $\mathrm{n} 56$, ch 1 'The lawyers of the thirteenth century did not shrink for declaring that the king, either by himself or through his servants, had committed a wrong...This is especially worth noticing because the theory was soon to develop that the king could not be a disseisor, and this theory was connected with the modern interpretation of the maxim, "the king can do no wrong."

${ }_{81}$ Bracton, $\mathrm{n} 22$, vol 2, p 33 'since no writ runs against him there will [only] be opportunity for a petition, that he correct and amend his act.' See also Holdsworth, n 9, vol 2, pp 253-6 \& vol 9, pp 9-10. For the petition in practice in Victorian times see Sunkin, n 12, p 236 (not available against the Crown in the case of tort). The Crown Proceedings Act 1947, s 13 and sch 1 abolished the petition of right and other archaic modes of proceeding against the Crown. See also Sunkin, n 12, pp 245 \& 345 (whether a citizen could proceed against the sovereign personally despite s $40(1)$ is unclear). See also Halsbury, n 1, para 14.

${ }_{82}$ Ibid, p 305 'as long as he [the sovereign] does justice he is the vicar of the eternal king, but the devil's minister when he deviates into injustice. For he is called rex not from reigning but from ruling well, since he is a king as long as he rules well.' Maitland, n 13, pp 100-3 also makes this point. The satirist Junius, writing in 1769, The Letters of Junius (London, printed for Vernor, Hood \& Sharp, 1810 ed), vol 1, p xxiv observed 'that the king can do no wrong...is not the only instance, in the wisest of human institutions, where theory is at variance with practice...exemption from punishment is a singular privilege annexed to the royal character, and no way excludes the possibility of deserving it. How long, and to what extent, a king of England may be protected by the forms, when he violates the spirit, of the constitution, deserves to be considered. A mistake in this matter proved fatal to Charles [Charles I, 1625-49] and his son.' Also, p 199 'That the king can do no wrong. We separate the amiable, good-natured prince, from the folly and treachery of his servants, and the private virtues of the man from the vices of his government.'

${ }^{83}$ Chitty, n 10, p 5. Further, as Allen noted, n 11, p 35 'the real king of the constitution is a king subject to law.' See Sunkin, n $12, \mathrm{p} 176$ for three 'common understandings of this maxim, viz. (a) whatever the sovereign does it cannot be wrong; (b) sovereign has no legal power to do wrong; (c) Crown is immune from legal process, save where legislation provides otherwise.' See also p 235.

${ }_{84}$ Ibid, 'the law provides no redress against the sovereign.' This is not strictly true since Parliament can 'remonstrate' against the sovereign. Allen, n 11, p 36 'we have this personal perfection qualified and curtailed by the undoubted right of the two houses of parliament to remonstrate against acts that are most properly and personally his own.' Petition by Parliament was also possible, such as the Petition of Right 1627. For the right of the individual to petition, see ns $79 \& 81$.

${ }_{85}$ Blackstone, n 8, vol 1, pp 238-9. Halsbury, n 1, para 2, n 1 . Also, para 367, n 2, 'In theory the monarch has supreme sovereignty and pre-eminence and under the doctrine of perfection can do no wrong. Cf. Re M [1994] 1 AC 377 at 395 per Lord Templeman 'The judges cannot enforce the law against the Crown as monarch because the Crown as monarch can do no wrong but judges enforce the law against the Crown as executive and against the individuals who from time to time represent the Crown.'

${ }^{86}$ Allen, $\mathrm{n} \mathrm{11,} \mathrm{p} 31$ 'to say there can be no wrong because there is no redress for it, is as reasonable as to maintain there can be no disease for which a physician has not a cure; and to argue that the prerogative cannot be exerted to the prejudice of the subject, because it was created for his benefit, is much the same as to assert, that an army, which has been raised in defence of the liberties of a country, cannot be employed for their destruction. But whence arises the impossibility of redress for wrongs done to the king? Because, in the contemplation of law, the 
- The first was that the sovereign had some form of divine sanction, being chosen by God ${ }^{88}$ This concept was overthrown by the Glorious Revolution of 1688 when Parliament elected the sovereign; ${ }^{89}$

- The second was a desire to protect the throne from being challenged, - or weakened - by legal means; ${ }^{90}$

- The third arose from the logical (and theoretical) difficulty that - since the courts were royal courts and the judges were the sovereign's appointees - how could they deliver judgment against the sovereign? ${ }^{91}$ There could be no remedy, no redress. ${ }^{92}$ As it is, the sovereign no longer appoints judges.

Today, the immunity - encapsulated in the legal fiction that the king can do no wrong in the wider sense of the 'Crown' - has gone. Although the sovereign remains personally immune from action in the courts, the Crown can be sued for wrongful acts. ${ }^{93}$ As Chrimes put it (in 1949):

Legally, the king can do no wrong, but his ministers and other servants can and sometimes do. It is common-law doctrine that the king cannot be presumed to have concurred in a wrong, and therefore servants of the Crown who commit a wrong cannot plead the Crown in justification. The king cannot be sued or be held legally responsible, but ministers and civil servants can be and are. ${ }^{94}$

Further, Ministers are accountable to the courts - and to Parliament - for all actions of Government ${ }^{95}$ the sovereign is only immune in a private capacity. ${ }^{96}$ Thus, the powers of the Crown are subject to Parliamentary and judicial control. ${ }^{97}$ Further, by convention, the powers of the Crown in relation to the UK are exercised on the advice of relevant ministers. ${ }^{98}$

In conclusion, the legal fiction that the sovereign can do no wrong is limited today to meaning that the sovereign is not justiciable in her own courts. Whether the sovereign should retain such an immunity will now be considered.

\section{(a) Sovereign - Criminal Immunity ${ }^{99}$}

\footnotetext{
king is sovereign and supreme.'

${ }^{87}$ PW Hogg, Liability of the Crown (Thomson Reuters, Australia, 4th ed, 1998), p 3 asserted (as did a number of other writers) that 'the reason why the king could not be sued in the royal courts was the feudal principle that a lord could not be sued in his own court'. See also Keir \& Lawson, n 12, p 70. However, as Jackson pointed out, 'the sovereign may possess an immunity which other feudal lords lacked. His rights were never merely the 'intensified rights of a feudal lord.' Whatever we mean by feudalism, kingship in England was not the product of a feudal system.' See P Jackson, Sovereign Immunity: A Feudal Principle (1975) 91 Law Quarterly Review, pp 171-2. See also Ehrlich, $\mathrm{n}$ 56, p 11 and Holdsworth, n 9, vol 3, pp 462-5 (no feudal lord could be sued in his own court).

${ }^{88}$ See Tanner, n 13, pp 22-4 (17th century conception of the divine right of kings). See also Holdsworth, n 9, vol 10, pp 4-6 and F Kern, Kingship and Law in the Middle Ages (Harper, 1970).

${ }_{89}$ Bill of Rights 1688, s 1 .

${ }^{90}$ See Bowyer, n 11, p 190. Also, 195. It would have been easy in medieval times for powerful magnates to destablise weak sovereigns using the authority of the law or engineering judges to help them. The idea that the sovereign must abide by the law and uphold his coronation oath was such, in part, to cause King John (1199-1216) to execute Magna Carta (in 1215) and to depose Richard II (1377-99).

${ }_{91}$ Blackstone, n 8, vol 1, p 231 'the king's prerogative stretcheth not to the doing of any wrong.' See also Finch, n 69 , p 55 'who shall command the king?' Cf. Sunkin, n 12, p 60 'The belief that the Queen can do no wrong presumably emerged from a conviction that the prerogative was created for the benefit of the people.'

${ }_{92}$ Anson, $\mathrm{n} 11$, vol 2, pp 20,30. This - one would assert - is the key meaning of the fiction - there was no legal redress against the sovereign. It was subscribed to by Maitland, n 13, p 100 'If the King breaks the law then the only remedy is a petition addressed to him that he will give redress.' Also, Holdsworth, n 9, vol 3, p 465.

${ }_{93}$ Halsbury, n 1, para 2, n 1 . Also, para 14 'Where the monarch acts with the co-operation of other persons, those persons are responsible for her acts. For since it is a maxim of the common law that the monarch can do no wrong, and therefore is incapable of authorising wrong to be done, they cannot defend themselves by pleading her orders. However, since the monarch cannot now in general act save in accordance with the advice and on the initiative of her ministers, there could be no question of pleading her orders for what they do. Accordingly, although the monarch may legally choose such ministers as she wishes, she cannot use them to circumvent the law. But she still has the right to be consulted, the right to encourage, and the right to warn. However, she also has the right to offer, on her own initiative, suggestions and advice to her ministers even when she is obliged in the last resort to accept the formal advice tendered to her.' See also Sunkin, n 12, pp 71-2.

${ }_{94}$ Chrimes, n 13, p 18 .

95 Ibid.

${ }^{96}$ Phillips, n 12, p 310 'The sovereign cannot be sued or prosecuted in the courts. The significance of this immunity was greatly diminished by the Crown Proceedings Act 1947, which enables the citizen to sue governmental departments in contract or tort for the recovery of property, while leaving unimpaired the sovereign's personal immunity.' Maitland, n 13, p 100 'against [the king], the law had no coercive process.'

${ }_{97}^{97}$ Halsbury, $\mathrm{n} 1$, para 2 'It is because the powers of the monarch are subject to parliamentary and judicial control that the monarchy is said to be constitutional'. See also Bogdanor, n 12, chs $1 \& 5$.

${ }_{98}$ Ibid, para 2 'The exercise of statutory powers exercised in the name of the Crown and of many prerogative powers is also subject to judicial review.'

${ }_{99}$ Blackstone, n 8, vol 1, p 235 'no jurisdiction upon earth has power to try him [the king] in a criminal way; much less to condemn him to punishment.'
} 
Prior to the trial of Charles I (1625-49) it would have been very difficult to impose criminal liability on the sovereign,

- In practice, only Parliament could do this, the judiciary being appointees of the sovereign. However, on the basis of 'might is right' the sovereign controlled the army and Parliament could not physically oppose him;

- This changed in 1688 when the Bill of Rights declared that the keeping of an army was illegal unless with the consent of Parliament. ${ }^{100}$ Also, in 1700 , the Crown's appointment of judges was removed. ${ }^{101}$

In modern times, the Queen has only a formal relationship with the courts and the armed forces. Thus, it is meet to re-consider the criminal liability of the same.

- The Prince of Wales - as well as other members of the royal family - has no such criminal or civil immunity, and this has caused no problems. Also, the punishment, in modern times, of various members of the royal family for minor infractions of the criminal law (such as road traffic offences) has neither shaken the Constitution nor undermined support for the royal family;

- Today, it is inconceivable that the sovereign - if she committed serious crimes such as murder, arson, fraud, accepting bribes etc - would be allowed to go 'scot free.' A failure to prosecute would, almost certainly, provoke a constitutional crisis. Not least - ever since Bracton - the prevailing jurisprudence is that the sovereign is ruled by the law. ${ }^{102}$ On such an event occurring, Parliament would likely enact legislation ending the legal fiction that the sovereign can do no wrong in the criminal sphere.

So, what should be done in modern times?

- It is asserted the criminal immunity of the sovereign should be lifted. At least, in respect of major crimes since it is inconceivable, if the sovereign were to commit same today, that she would be allowed to escape prosecution;

- Consideration should be given to removing the criminal liability of the sovereign in toto since - in practice - it is most unlikely to create a problem. ${ }^{103}$ Also, it reflects prevailing the reality that the sovereign's role in connection with the law and the courts is now only a formal one.

In conclusion, it is asserted the sovereign's criminal immunity should be lifted. At least, in relation to major criminal offences.

\section{(b) $\underline{\text { Sovereign - Civil Immunity }}$}

Just as the case for lifting the criminal immunity of the sovereign in modern times seems reasonable, the case for preserving civil immunity seems reasonable in order to prevent the sovereign from being troubled by spurious or politically motivated - law suits. ${ }^{104}$ There would seem to be a good case, however, in making exceptions where the sovereign:

(i) incurs personal debts; or

(ii) creates a pledge, lien or mortgage over her personal property.

Analysis of this has been undertaken in a previous article. The prevailing law (which is very antiquated) appears to be as follows:

- Pledge. There was (and is) nothing in law to prevent the sovereign from pawning her own property. In times past, sovereigns often pledged the Crown jewels, regarding them as items of personal property ${ }^{105}$ (today, Crown jewels belong to the nation). ${ }^{106}$ Thus, in Anon (1465), Henry VI (1422-61 and 1470-71)

\footnotetext{
${ }^{100}$ Bill of Rights 1688 'the raising and keeping a standing army within this kingdom in time of peace unless it be with the consent of Parliament is against law.'

101 Act of Settlement 1700 (judicial tenure declared to be during good behaviour).

102 See n 22.

103 S Sedley, The Sound of Silence: Constitutional Law without a Constitution (1994) 110 LQR 270 at p 289 'it is not inexorable in a constitutional monarchy that the monarch cannot be given a parking ticket like the rest of us.' Sunkin, n 12 , p 345 'in a constitutional monarchy perhaps there is no reason why the sovereign should be free to break the criminal law.'

104 If the sovereign was in and out of court she would be unable to perform her duties.

105 See GS McBain, Modernising the Monarchy in Legal Terms - Part 4. (2012) KLJ, vol 23, 285-311.

106 Halsbury, n 1, vol 12(1) para 374 'The Crown may not grant away the jewels of the Crown, which are heirlooms and as such do not pass to the executor.' When the wife of Charles I (1625-49) sold various Crown jewels in Holland, Parliament held that it was 'not in the king's
} 
pawned some of the Crown jewels for $£ 100$. Later, he obtained judgment for the return of the same, without paying the debt. More unjustly, the pawnee was fined and imprisoned - even though there was no evidence of skulduggery on his part. ${ }^{107}$ It is asserted this case would not be followed today since it is excessively harsh. Also, if the Queen pawns her own property there is no good (moral) reason why a pawnee should not be entitled to enforce the pawn against her on non-payment, as applies with every other person. In other words, it is unjust to allow the sovereign to escape from a pledge which she has voluntarily entered into;

- $\quad$ Lien. There was (and is) nothing to prevent the sovereign from creating a lien over her property. For example, where a person works on the personal possessions of the Queen to improve them. Today, there would also seem no good reason to permit the Queen to avoid liability on the non-payment of a lien debt; ${ }^{108}$

- Debts. At common law, a creditor cannot execute payment against the sovereign for debts incurred by the same. ${ }^{109}$

The fact that the sovereign was immune from civil liability in the past, did not mean that no remedy was available. At least from the time of James I (1603-25), the sovereign could be petitioned in Chancery to pay his debts. Payment was then made as a matter of grace, not legal compulsion. ${ }^{110}$

In conclusion, it is asserted the sovereign should be legally liable to pay her debts and to accept the enforcement of security against her - like everyone else. Lifting immunity in this area would not seem problematic since there is little likelihood, in practice, of the sovereign pledging (or mortgaging or creating liens over) her own property $^{111}$ or incurring debts which she later fails to pay, given that she is a very wealthy individual.

\section{Prerogatives Relating to Allegiance \& Parens Patriae}

The basic relationship between the sovereign and subject is protection accorded by the former in return for allegiance accorded by the latter. ${ }^{112}$ This relationship is conceived of as a personal one; the sovereign is 'liege lord', the subjects 'liege subjects'. ${ }^{113}$ Halsbury notes:

English law is still informed by the ancient conception of the relationship between the individual and the state as being one between the subject and the monarch. The relationship of subject and monarch was conceived of as a personal one, involving a bargain under which the monarch gave the subject protection and undertook to govern according to the laws of the land, and the subject owed the monarch legally enforceable allegiance. It did not involve the subject having any legally enforceable rights against the Crown, and the duties of protection owed by the Crown were not justiciable. With the development of the principle of legality the individual has become progressively emancipated from the control of the monarch or Crown and now has a high degree of autonomy and personal liberty. ${ }^{114}$

power to dispose the jewels of the Crown.' See Edward, Earl of Clarendon, The History of the Rebellion and Civil Wars in England (Oxford, Clarendon Press, 1827), vol 2, p 905. Also, pp 772 \& 945-6.

107 Anon (1456) Jenk 83 (145 ER 59). The case states 'The king had judgment to have his jewels; the defendant was fined and imprisoned...' See also McBain, n 105, pp 302-4.

108 McBain, n 105, p 304

109 Ibid, p 302. Chitty, n 10, p 376 'The king's goods are also exempt from various liabilities, which affect the personality of his subjects. Even if a subject succeed in a petition against the king, his majesty's goods are not liable to be taken in execution.'

110 See $n$ 79. The Stuarts were notoriously bad at settling debts. However, one would assume that - from the time of Queen Victoria [1837-1901] - sovereigns were careful to ensure personal debts were paid (or not to incur the same). In the reign of Queen Elizabeth I (1952- ) there has been no suggestion that she does not pay personal debts (albeit payment is not made in person).

111 In respect of real property, the sovereign owns Sandringham (purchased in 1861) and Balmoral (purchased in 1850 by Albert, husband of Queen Victoria) as her personal property. Also, possibly, some other estates. The sovereign also owns many jewels and other items of great value. Indeed, she is reputed to be one of the richest women in the world.

112 The Crown's duty towards the subject rested originally upon a semi-feudal bond, whereby the king, as liege lord, was bound to maintain and defend his people in return for service and obedience. Calvin's Case (1608) 7 Co Rep $1^{\mathrm{a}}$ at $4 \mathrm{~b}$ (77 ER 377) 'as the subject oweth to the king his true and faithful legeance and obedience, so the sovereign is to govern and protect his subjects.' Also 'it is truly said that protectio trahit subjectionem, et subjectio protectionem.'

113 Halsbury, n 1, para 29 'As, in feudal phraseology, the king was styled 'liege lord', so his subject were termed 'liege subjects', and were bound as such to serve and obey him. Hence the duty of the subject towards the monarch is known legally as allegiance.' Allegiance may be natural, local or acquired. Local allegiance is due from all persons resident within the realm, and so long as they or their families or effects remain within the monarch's protection, they are punishable as traitors for acts of treason, whether their country is at amity with this country or not; but allegiance is not due from an alien enemy coming to invade the realm.'

114 Ibid, n 1, para 26. 
As Halsbury notes, the practical effect of owing allegiance is potential liability for the crime of high treason, a few sub-crimes of which still exist.

- Previous articles ${ }^{115}$ have asserted that high treason should be abolished - apart from the sub-crime of 'adhering to the enemy' which (it is asserted) should be replaced by a crime of treachery;

- Reasons for abolition include the fact that, today, it is often difficult to determine whether a person owes - or does not owe - allegiance to the sovereign (e.g. British subjects who hold dual passports or who reside permanently abroad, retaining no links to this country). ${ }^{116}$

Leaving aside this liability to high treason - by virtue of allegiance ${ }^{117}$ - the Crown has the prerogative to compel subjects to serve as parish constables or sheriffs. Some legal commentators suggest this prerogative is even wider and the Crown can also compel those who owe allegiance to serve in any public office. However, this is more dubious. The position would appear to be as follows:

\section{(a) Duty to Serve: Sheriff or Parish Constable}

There is a duty imposed on those who owe allegiance to serve - if called on by the Crown - as a sheriff $\mathrm{f}^{18}$ or parish constable. ${ }^{119} R v$ Larwood (1694) concerned the refusal of the same to take upon him the office of sheriff in a corporation. The court stated:

the king has a natural interest in every subject, and may compel him to serve him in any function, in which he shall judge him capable...And nobody can be exempt from the office of sheriff but by Act of Parliament, or letters patent. ${ }^{120}$

As Halsbury notes, these obligations are now 'theoretical' for good reason. ${ }^{121}$

- $\quad$ Parish Constables. Prior to the beginnings of a professional police force in 1829 , the obligation to serve as a constable was an onerous one. One which any person of ability avoided since it was usually unpaid, part time and problematic. ${ }^{122}$ Refusal to so act was (and is) held to be a crime, punishable with a fine or imprisonment for life (or a shorter term) unless some other penalty was imposed. ${ }^{123}$ Defences included proving that the person was exempt - or disqualified - from serving; ${ }^{124}$ Parish (petty) constables who were village or town constables (and 'high constables' who were constables of the hundreds) were replaced in Victorian times by professional police forces acting under a chief constable (appointed by Justices of the Peace). This resulted from the Metropolitan Police Act 1829 and the County Police Act 1839. No parish constables exist today;

\footnotetext{
115 (a) GS McBain, Abolishing the Crime of Treason (2007) 81 Australian Law Journal 94-134; (b) GS McBain, High Treason: Killing the Sovereign or Her Judges (2009) 20 King's Law Journal 457-88; (c) GS McBain, High Treason: Violating the Sovereign's Wife (2009) Legal Studies, vol 29(2) 264-80.

116 See McBain, n 115, article (a). Also, Halsbury, n 1, para 31 and Tejendrasingh v Lord Adrian (1971) The Times, 12 January.

${ }_{117}$ Maitland, $\mathrm{n} 13$, pp 501-6 noted various obligations arising from allegiance.

118 Halsbury, n 1, vol 42, paras 1101-7.

119 Ibid, vol 36, para 101 'in 1872 an Act was passed [Parish Constables Act 1872, rep] rendering the general appointment of parish constables unnecessary'. DM Walker, The Oxford Companion to Law (Clarendon Press, Oxford, 1980, extract on 'parish') 'In the twentieth century the parish has ceased to be an area or unit for administrative purposes, all functions having been transferred to units dealing with larger areas.'

${ }_{120}$ (1694) 1 Ld Raym 29 (91 ER 916) at p 32. See also Maitland, n 13, pp 502-3. He referred to an Act of 1831. It imposed a statutory duty to serve as a parish constable or to find a substitute if between 25-45 years of age and rated at a poor rate of $£ 4$ or more. He then stated: 'The power of forcing men to serve as parish constables might be put in force if the justices at Quarter Sessions thought fit, but as a matter of fact owing to the creation of the professional police forces it is found unnecessary.'

${ }^{121}$ Halsbury, n 1, para 27.

122 JF Stephen, A History of the Criminal Law of England (London, Macmillan \& Co, 1883), vol 1, p 196 'Nothing could exceed the inefficiency of the constables and watchmen. Of the constables, Dalton....observes that they 'are often absent from their houses, being for the most part husbandmen, and so most of the day in the fields.' The charge of Dogberry shows probably with no great caricature what sort of watchmen Shakespeare was familiar with.' See also M Dalton, The Countrey Justice (London. For the Society of Stationers. 1619), pp 39-40. 123 See GS McBain, Abolishing some Obsolete Common Law Crimes (2009) 20 King's Law Journal, at p 113.

124 See Chitty, n 10, p 20-1. It is likely that many exemptions were given, on payment of a fine. Reference is also made by Chitty of exemption being given in respect of sheriffs and aldermen and sheriffs of the City of London, which offices were usually financially onerous. See also GS McBain, Liberties and Customs of the City of London - Are there any Left? International Law Research (2013), vol 2, no 1, pp 1-64. See F Bacon, Law Tracts (In the Savoy, printed by E \& R Nutt \& R Gosling, 1737), pp 181-2 for the distinction between parish and high constables.
} 
- $\quad$ Sheriffs. These were another form of law enforcement officer. ${ }^{125}$ Today, they exist only as 'high sheriffs' - an honorary position which does not involve any police duties.

In the case of a refusal to serve in these positions of parish constable and sheriff, Halsbury and Archbold cite only four cases, all of which are very antiquated. The last case appears to have been in 1832 , more than 180 years ago. ${ }^{126}$

In conclusion, parish officers no longer exist and high sheriffs comprise a ceremonial position only. Therefore, there is no need for the Crown to retain a prerogative to compel subjects to so serve.

\section{(b) Duty to Serve: Any Public Office}

Some legal writers have suggested that the Crown has a prerogative to compel those owing allegiance to serve in any public office. Thus, Chitty stated in 1820 :

His majesty may also, on any occasion, employ, and compel his subjects to serve in such offices or functions as the public good and the nature of the constitution require. It is a general rule, that where a person is called upon to perform a public duty, he is liable to be punished if he refuses to perform it.... This doctrine is not confined to the case of offices immediately under the Crown nor to officers appointed by his majesty; for persons named jurymen ${ }^{127}$ or parish officers must serve. ${ }^{128}$

In support of this proposition, Chitty referred to the fact that:

- A lawyer was bound to accept the degree of sarjeant-at law, when called on by the king's writ;

- A dignity of honour could not be legally refused;

- A person summoned by the sovereign to the House of Lords, was obliged to accept;

- A person elected to the House of Commons, was obliged to accept.

None of these grounds now apply, sarjeants-at-law in any case no longer existing. Further, there is actually little caselaw (as opposed to dicta) which supports such a wide proposition. ${ }^{129}$ In respect of this proposition, Maitland (writing in 1908) stated:

it is a very general, if somewhat antiquated, doctrine of the common law that a person is bound to serve the crown in all manner of offices. We see this chiefly applied in the case of sheriffs: a person who has sufficient land in the county to qualify him for the office (a vaguely defined amount) is bound to serve if he be appointed and can be fined if he refuses. This is, I think, but an instance of a general principle which exists, though it is seldom put in force. Could a man be punished for refusing to become Chancellor of the Exchequer or Secretary of State? It is absurd to consider such a case, but I imagine that he could. ${ }^{130}$

Over 100 years after Maitland wrote, it would be absurd to conceive of a person being so punished - not least since persons can (and have) refused to so serve. Further, the Crown often granted exemptions in any case. ${ }^{131}$ Today, there seems to be an insuperable problem with the retention of such a Crown prerogative, besides its being obsolete. Legislation cannot, generally, compel a person to work - whether by injunction or otherwise. ${ }^{132}$ Thus, a Crown

125 For the position of parish constables by 1844 , see Stephen, n 122, vol 3, pp 45-52.

${ }^{126} R v$ Denison (1758) 2 Keny 259 (96 ER 1175) (mayor of Leeds), $R v$ Woodrow (1788) 2 TR 731 (100 ER 393 ) (sheriff of Norwich), $R v$ Bower (1823) 1 B \& C 585 (107 ER 215) (common councilman of the borough of Lancaster), $R v$ Brain (1832) 3 B \& Ad 614 (110 ER 224) (vestry constable).

127 This is no longer the case.

128 Chitty, n 10, pp 18-9.

129 The highpoint is really a dictum of Lord Ellenborough in Morris v Burdett (1813) 2 M \& S 212 (105 ER 361 (the case concerned a person made a candidate MP for Westminster without his consent). Per Lord Ellenborough at $\mathrm{p} 218$, 'it should seem that in every case where a person is called upon to perform a public duty, he is liable to be punished for refusing to perform it. To instance in one particular only, a sarjeant at law is liable to punishment, for not taking upon himself that degree after being called thereto by the king's writ'. See also Coke, $\mathrm{n}$ 7, vol 2, p 214 (various barristers charged to become sarjeants by Parliament in 1418). Also, Viner, n 6, vol 16, p 572.

${ }^{130}$ Maitland, n 13, p 504.

${ }^{131} R v$ Larwood (1694) 1 Ld Raym 29 (91 ER 916) at p 32 (he pleaded as a defence he was a protestant dissenter). In $R v$ Clarke (1787) 1 TR 679 (99 ER 1317) it was held that a younger brother of the corporation of Trinity House was not exempt from serving the office of headborough (i.e. a local policemen, such no longer exist). It was also held that the Crown could grant exemptions, provided a sufficient number of persons were left to serve.

${ }^{132}$ Trade Union and Labour Relations (Consolidation) Act 1992, s 236 'No court shall, whether by way of - (a) an order for specific implement of a contract or employment, or (b) an injunction to interdict restraining a breach or threatened breach of such a contract, compel an employee to do any work or attend at any place for the doing of any work.' WO Russell, On Crime (Stevens, London, 12th ed, 1964), p 372 (published in 1964) 'Indictments for this offence have not been presented for many years, and the existing precedents appear to apply only to parochial or corporate offices filled by election, except one, which relates to the refusal of a sheriff to take up his office or 
prerogative to compel a person to act in a public office of a contractual nature has been, effectively, superceded by a legislative prohibition.

In conclusion, any Crown prerogative to compel a person to accept a public office - or just to act as a parish constable or a sheriff - should be abolished. It is no longer required. Further, it would not seem to be enforceable in practice.

\section{(c) Crown as Parens Patriae}

As 'liege lord', the Crown asserted a prerogative to supervise the persons and estates of: (a) minors; and; (b) the mentally disordered. Also, (c) to supervise charities. As Halsbury notes, these functions have been taken over by the State or other institutions. Thus:

As liege lord and protector of the subjects, the monarch enjoys the prerogative right of taking care of the persons and estates of minors and mentally disordered persons and of superintending charities, although the exercise of those powers has now been delegated by the monarch or assigned by statute to various authorities. Jurisdiction in respect of wardships of minors and the care of their estates is expressly assigned to the family division of the high court of justice, whilst local authorities have duties in respect of children in need of care and control. ${ }^{133}$

The prerogative of taking care of mentally disordered persons and their estates is no longer exercised, that function being now carried out under statute by the Court of Protection. The prerogative in matters relating to charities is exercised largely by the Lord Chancellor, and the administration of charities legislation is the function of the Charity Commissioners. ${ }^{134}$ (wording divided for ease of reference)

Given this, any Crown prerogative in respect of minors, the mentally disordered and supervising charities should be abolished and these functions should be placed on a statutory basis. This will clarify - and ascribe jurisdiction to those institutions which have assumed these functions in practice.

In conclusion, the Crown prerogative to act as parens patriae should be abolished and any remaining legal jurisdiction in respect of minors, the mentally disturbed and charities should be passed-by statute - to relevant State institutions.

\section{Crown Prerogative - Making War and Peace}

It is a constitutional proposition that the sovereign alone has the prerogative to make war (both in and outside the realm $)^{135}$ as well as to make peace. This has been held - as least - from the Norman Conquest of $1066^{136}$ and, likely, it existed even prior to this.

- Indeed, one would suggest this was the pre-eminent prerogative of the sovereign who was likely chosen for this martial prowess in Anglo-Saxon times - especially when England was subject to waves of Saxon and Nordic invaders after the departure of the Romans in AD 410; ${ }^{137}$

\footnotetext{
appointment.'

33 Bradley, n 1, p 253 'The courts may interfere 'for the protection of infants, qua infants, by virtue of the prerogative which belongs to the Crown as parens patriae.' See also In re Spence (1847) $2 \mathrm{Ph} 247$ (41 ER 937). For the position in 1934, see Ridges, n 13, p 196.

134 Halsbury, n 1, para 309. For the position in 1820, when the Crown had greater control, see Chitty, n 10, pp 155-62. See also Bradley, n 1, pp 253-4. See also Holdsworth, n 9, vol 10, p 356. Also, Keith, n 13, pp 337-8, 'nothing...of personal concern is left to the monarch in spheres which once were of special interest to the medieval sovereign, mainly, of course, for the substantial revenues which might be derived from exercise of these high prerogatives.' See also DeSmith \& Brazier, n 13, pp 143-4 'In so far as the prerogative of protection encompasses the superintendence of charities and the welfare of persons of unsound mind, it appears to have been almost entirely engulfed by statute.'

${ }^{135}$ In Rustomjee v R (1876) 2 QBD 69, 73, per Coleridge CJ 'The making of peace and the making of war, as they are undoubted, so they are perhaps, the highest acts of the prerogative of the Crown.' See also Phillips, n 12, p 321. To make war against the sovereign in the realm (i.e. civil war) was (and is) high treason under the Treason Act 1351 (levying war against the sovereign). To join with foreigners and made war against the sovereign was also high treason under the Act (the crime of 'adhering to the enemy'). See $n$ 115, article (a).

${ }^{136}$ FCT Tudsbery, Prerogative in Time of War (1916) Law Quarterly Review, vol 32, p 384 'The defence of the realm has by our constitution been entrusted to the Crown, and from the time of the Norman Conquest onwards the military forces in the United Kingdom have always been maintained by the Crown as the authority responsible for the defence of the kingdom.'

${ }^{137}$ That said, early collections of Anglo-Saxon laws do not specifically advert to this. See, for example, AJ Robertson, The Laws of the Kings of England from Edmund to Henry I (Cambridge UP, 1925) and FL Attenborough, The Laws of the Earliest English Kings (New York, Russell \& Russell, 1963).
} 
- Further, the sovereign invariably went into battle with his troops - this physical evidence of martial sovereignty only ending with George II (1727-60) who fought at Dettingen in 1743, some 270 years ago. $^{138}$

Although this prerogative may not have been stated - as such - in the earliest legal texts, commencing with Glanvill's Treatise on the Laws and Customs of the Realm c. $1189^{139}$ it was enunciated by Sir Thomas Smith, in his De Republica Anglorum, written c. $1562-5^{140}$ and Coke (in his work published in 1641) stated :

no subject can levy war within the realm without authority from the king, for to him it only belongeth. $^{141}$

Similarly, Hale, in his History of the Pleas of the Crown (written in the 1640's but first published in 1736), stated:

The power of making war or peace is inter jura summi imperii, and in England is lodged singly in the king, tho it ever succeeds best when done by parliamentary advice. ${ }^{142}$

Blackstone, in 1765, summarised this prerogative - together with the legal rationale - as follows:

the king has...the sole prerogative of making war and peace. For it is held by all the writers on the law of nature and nations, that the right of making war, which by nature subsisted in every individual, is given up by all private persons that enter into society, and is vested in the sovereign power: ${ }^{143}$ and this right is given up not only by individuals, but even by the entire body of people, that are under the dominion of a sovereign. It would indeed be extremely improper, that any number of subjects should have the power of binding the supreme magistrate, and putting him against his will in a state of war. ${ }^{144}$

Chitty, in 1820 , wrote: ${ }^{145}$

As representative of his people, and executive magistrate, the king possesses...the exclusive right to make war or peace, either within or without his dominions; and the constitution leaves it to the king's discretion to grant or refuse a capitulation or truce to an enemy... ${ }^{146}$ The king alone has a legal discretion on this subject, under any circumstances which may occur; and though a kingdom which professes to be neutral, should commit the most flagrant acts of aggression and injustice towards this country, and trample on every duty enjoined by the law of nations, still the king alone can legally declare war against it. ${ }^{147}$

\footnotetext{
${ }^{138}$ The last time a sovereign led his troops into battle was George II (1727-60) in 1743 at the battle of Dettingen. He is also said to have told Sir Robert Walpole, his prime minister, in 1737, 'I will order my army as I see fit.' See Lord Hervey, Memoirs of the Reign of King George II (ed. Sedgwick, 1931), p 771

139 Glanvill (ed GDG Hall), The Treatise on the Laws and Customs of the Realm of England (Nelson, 1965).

140 T Smith, De Republica Anglorum, (ed Dewar, CUP, 2009), p 85 'the monarch...has absolutely in his power the authority of war and peace, to defy what prince it shall please him, and to bid him war, and again to reconcile himself and enter into league or truce with him at his pleasure or the advice only of his privy council.' (spelling modernized).

${ }^{141}$ Coke, n 7, vol 3, p 9. He cited A Fitzherbert, New Natura Brevium (written in 1554), 113a, 'the King of right ought to keep and defend his kingdom....against enemies that it be not...wasted, and to provide remedy for the same.' See also Calvin's Case (1608) 7 Co Rep $1^{\text {a }}$ (77 ER 377 ) at $25 \mathrm{~b}$ 'Wars do make aliens enemies, and bellum indicere [to make war] belong only and wholly to the King, and not to the subject, as appeareth in $19 \mathrm{Ed} 4.4$ fo 6. This is a reference to YB $19 \mathrm{Edw} 4 \mathrm{pl} 4$ fo $6^{\mathrm{a}}$ (1480), see Seipp Index no 1480.004 (see $\mathrm{n} 60$ for Index). In this case, Brooke, n 5, Denizen reports Bryan CJCP stating 'si touts d engliterre voient fayre guerre ove le roy de Denmark, \& le roy ne voet a ceo assenter, ceo n est guerre.' which Chitty, n 10, p 44 translates as 'if all the people of England would make war with the king of Denmark, and our king will not consent to it, this is not war.'

${ }^{142}$ Hale, n 60 , vol 1, p 159. As to peace, Hale distinguished between temporary and permanent peace. Today such categorisation is not necessary. Ibid, pp 159-60. See also M Hale, Of Sovereign Power (reprinted in Holdsworth, n 9, vol 5, p 508 'He has the only power of making peace and declaring war.' (spelling modernised).

${ }_{143}$ Blackstone quotes Samuel von Pufendorf (1632-94), Of the Law of Nature and Nations (De Jure Naturae et Gentium, 1625), f $18 \mathrm{c} 6 \mathrm{~s} 8$. See also S Pufendorf, The Whole Duty of Man, according to the Law of Nature (1673, trans. D Saunders, Liberty Fund, 2003), p 240, 'the power of making war, in all nations lies in the same hands, that are entrusted with the government.' This view - that it was for the sovereign to make war - was followed by other Continental writers e.g. JG Heineccius, A Methodical System of Universal Law (1738, trans. G Turnbull, Liberty Fund, 2008), p 500 (for the sovereign 'to declare war, wage war against an enemy.') and JJ Burlamaqui, The Principles of Natural and Politic Law (2nd ed, 1763, trans T Nugent, Liberty Fund, 2006), p 448 'it is certain that the sovereign, in whose hands the interest of the whole society is lodged, has a right to make war.' See also Sir William Scott in The Hoop (1799) 1 C Rob at 199 'By the law and constitution of this country, the sovereign alone has the power of declaring war and peace...'

${ }^{144}$ Ibid, n 8, vol 1, p 249. He continues 'Whatever hostilities therefore may be committed by private citizens, the state ought not to be affected thereby; unless that should justify their proceedings, and thereby become partner in the guilt.'

${ }^{145}$ Chitty, n 10, p 45.

${ }^{146}$ Blackstone, n 8, vol 1, p 245 'What is done by the royal authority, with regard to foreign powers, is the act of the whole nation: what is done without the king's concurrence is the act only of private men. And so far is this point carried by our law, that it hath been held, that should all the subjects of England make war with a king in league with the king of England, without the royal assent, such war is no breach of the league'. He quoted Coke, n 7, vol 4, p 152 which referred to the statement of Bryan (see n 141).

${ }_{147}$ Chitty, n 10, p 45 cited Hagedorn v Bell 1 M \& S 449 (105 ER 168) which held that - although a State might be in the military possession
} 
In more modern times, under the heading 'The making of War and Peace', Halsbury - citing Blackstone - states:

War can be commenced or terminated only by the authority of the Crown. ${ }^{148}$

This statement, while indubitably correct, is too bald since the making of war and peace by the Crown has encapsulated, in law, a number of other, lesser, prerogatives:

- The prerogative to declare war and peace;

- The sovereign being head of the armed forces;

- The prerogative to enter the land of subjects to erect fortifications;

- The prerogative to requisition British ships;

- The prerogative to impose blockades and embargoes;

- $\quad$ The prerogative to booty, prize and angary;

- The prerogative to prohibit subjects from leaving the country - as well to recall subjects, ${ }^{149}$

- $\quad$ The prerogative to compulsorily enlist subjects, including impressing them for the navy. ${ }^{150}$

If the primary Crown prerogative - to make war and peace - is transferred to Parliament then it seems clear these others should also be transferred (to the extent they are still of validity) in order that they, too, are subject to Parliamentary oversight. As for the Crown prerogative to make war and peace - in early times - it would have been inconceivable to most subjects that the sovereign not have such a prerogative, for the following reasons:

- $\quad$ No Standing Army - Obligation on Sovereign to Raise Army. There was no standing army until 1688. Therefore, it was the duty of the sovereign - ever since a system of land tenure based on military duty was instigated by William I (1066-87) - to invoke the terms of that tenure in order to assemble an army whenever there was a threat of war (whether civil or from external enemies). ${ }^{151}$ Also, if required, it was the duty of the sovereign to recruit additional troops by: (a) invoking commissions of array; (b) hiring troops (including foreign mercenaries) by indenture (i.e. by contract ); (c) impressing subjects to serve in the navy (and, more rarely, the army); ${ }^{152}$

- $\quad$ Sovereign led Troops. The sovereign was commander-in-chief of the army and had the duty to lead his troops into battle; ${ }^{153}$

- $\quad$ Feudal Bond. The likely underlying rationale to a medieval mind for the sovereign's right to make war and peace was the feudal bond of allegiance in which the sovereign provided protection (protectio trahit subjectionem, et subjectio protectionem $)^{154}$ and the subject, as a result, could be obliged to bear arms in the case of sudden invasion or formidable insurrection; ${ }^{155}$

\footnotetext{
of one or two belligerents - it would not constitute her subjects enemies to the other belligerent, if the sovereign power of the latter permitted a continuance of commerce with them. It dealt with the situation of Hanover, occupied by the French with whom England was at war. The subjects of Hanover were not held to be enemies of England. Bowyer, n 11, p 223 'this country can never be at war except by the authority of the sovereign.'

${ }^{148}$ Halsbury, n 1, para 810 citing the $14^{\text {th }}$ edition of Blackstone (published in 1803), pp 257-8. Comyns, n 6, vol 1, p 45 'the king has the sole authority to declare war or peace.' Bacon, n 6, vol 5, p 532 'The power of making war and peace...is lodged singly in the king, though, as Lord Hale says, it ever succeeds best when done by parliamentary advice.' The reference is to Hale, n 60, vol 1, p 130 'The jus gladii, both military and civil, is one of the jura maiestatis, and therefore no man can levy war within this kingdom without the king's commission.' Keith, n 13, p 341'The right to make war vests in the Crown ...The power to make peace is likewise vested in the Crown, and is part of the treaty power.' Maitland, n 13, pp 423-4 'the prerogative of making war and peace. This power...belongs to the king.' See also Anson, $\mathrm{n}$ 11, vol 2, pp 136-7. Bacon, n 124, p 179 'The King hath power to declare and proclaim war, and to make and conclude peace and truce at his pleasure.'

${ }_{149}$ This I have placed in italics on the basis it is obsolete, see 12. See also Chitty, n 10, pp 21-5.

150 Ibid.

151 See McBain, n 58, p 16.

${ }^{152}$ Ibid. Sunkin, n 12, p 347 'Would the prerogative ever be used to impress men (or even men and women) into the royal navy?' In fact, the prerogative can only be used against men (at least, it has only been used to impress men in the past). See also Bowyer, n 11, ch 27.

${ }^{153}$ In early times, the failure of a sovereign to lead the army provoked problems. For example, in 1297, Edward I (1272-1307) sought to raise money for war in France by way of a tallage (tax). Roger Bigod (Earl of Norfolk and Suffolk and Marshall of England) and Humphrey de Bohun (Earl of Hereford and Essex and Constable of England) were reluctant to go to France unless Edward I himself went. See GS McBain, Modernising the Monarchy - in Legal Terms (2010) KLJ, vol 21(3), 535-60. Also, Coke, n 7, vol 2, p 528. There was also an incentive to the sovereign to attend in person since the ransom of all prisoners belonged to him by virtue of Crown prerogative. Hale, $n$ 10, $p$ 132.

${ }^{154}$ Chitty, n 10, p 12 'The King is entitled, morally as well as legally, to the allegiance of his subjects, in return for the protection and security which his majesty constitutionally affords them.'

${ }_{155}$ Ibid, pp 46-7. It has been asserted there is no such Crown prerogative, in fact. See McBain, n 58, pp 52-5.
} 
- Parliament had no Authority to raise Army. There was no one else besides the sovereign who had authority to assemble an army, ${ }^{156}$ since the relationship of Parliament to the sovereign was - usually - a subservient one until 1688 when the sovereign was chosen by Parliament.

Thus, until 1688, there was no one besides the sovereign with the authority or capacity to raise and control the armed forces. British history vividly shows that the rash making of war by sovereigns often had huge detrimental financial (and human) consequences for the country. While not challenging the prerogative directly, Parliament had some indirect means of trying to prevent sovereigns entering into foolish foreign wars: ${ }^{157}$

- Obligation of Subjects to Fight Abroad Limited. Legislation - commencing from medieval times restricted the capacity of the sovereign to require subjects to go to war outside the realm or to finance foreign wars. ${ }^{158}$ Although Coke summarised these limitations in a work published in 1628 in a 'clear-cut' fashion, in practice, strong kings got their way despite the legislation; ${ }^{159}$

- Professionalising the Military. Military tenure soon became substituted for one of payment in lieu (scutage or escuage). This commenced from the time of Henry II (1154-89) and the additional system of indenture seems to have lapsed after the accession of Edward IV (1461-70 and 1471-83). Thus, for armies, sovereigns relied more and more on mercenaries - often foreign ones - rather than their subjects. ${ }^{160}$ The result was that armies became more professional and costly - beyond the financial resources of the Crown. As a result, Parliament became more intimately involved in financing (by way of a supply) the costs of war;

- Loss of Possessions Abroad. After the Crown lost its possessions in France, the incentive to embark on foreign wars lessened. The need for armies for foreign adventures was offset by a greater use by the sovereign of the navy - as well as the impressment of mariners, where required; ${ }^{161}$

- $\quad$ Stuarts - Strong Challenge to the Prerogative by Withholding Supplies. The designs of the Stuarts to assert an absolute monarchy were opposed by Parliament. As part of this, Parliament thwarted the attempt of James I (1603-25) to successfully undertake foreign engagements, by refusing adequate financial supplies. ${ }^{162}$ While this did not deny the sovereign's undoubted prerogative to make war (or assist allies) it could severely hinder it - especially when James I was impoverished. The same happened in the case of Charles I (1625-49); ${ }^{163}$

- Increasing Control by Parliament. Although, in 1660, it was accepted in legislation that Charles II (1660-85) was commander of the army, ${ }^{164}$ his relationship with Parliament was often strained since

\footnotetext{
${ }^{156}$ For any individual to seek to assemble an army ran a real risk of being accused of high treason. See $\mathrm{n} 115$, article (a).

157 A large amount of British history pre-1745, concerns civil wars not foreign ones. In the former, the right of the sovereign to defend himself was invariably upheld by Parliament and those who were opposed him were held to have committed treason. In the case where the sovereign was wholly inadequate, Parliament usually avoided making war. Instead, in the case of kings such as Richard II (1377-99) and Edward II (1307-27) it recognised the legitimacy of their successors. The failure of Parliament to support later challenges - such as those of Monmouth in 1685 and the Jacobite rebellions of 1715 and 1745 - was fatal to any long term success of the same.

${ }^{158}$ Coke, n 7, vol 2, p 528 summarised this legislation as 'No man shall be charged to arm himself, or to find men of arms, or any hoblers [a soldier who rode a 'hobby' or light horse] or archers...if it be not by common consent, and grant in parliament'. (spelling modernised). Also, 'No man shall be compelled to go the king's war out of his shire, but where necessity of sudden coming of strange enemies into the realm...No man shall be charged to give any wages either to the preparers or conveyors of soldiers, or to the soldiers to go into Scotland, Gascony, or elsewhere; but that men of arms, hoblers and archers, chosen to go into the king's service out of England, shall be at the king's wages from the day they depart out of the counties where they were chosen, till they return.' Coke stated that such legislation was 'but declarations of the ancient law of England.' (spelling modernised). See also Holdsworth, n 9, vol 10, p 377 and Bowyer, n 11, pp 662-3. Finch, n 69, p 56 'He [the sovereign] may command his subjects to go out of the realm in war.' See also Viner, n 6, vol 16, p 568.

159 Although individual magnates did seek to temper the warlike ambitions of persons like Edward I (1272-1307), Edward III (1327-77) or Henry VIII (1509-47) they invariably courted royal displeasure. Coke, n 7, vol 2, p 528 admitted as much when he stated 'here may be observed, that when any ancient law or custom of parliament is broken, and the crown possessed of precedent, how difficult a thing it is to restore the subject again to his former freedom and safety.'(spelling modernised)

${ }_{160}$ Summarised in McBain, $\mathrm{n} 58, \mathrm{p} 16$.

161 The Crown lost Calais in 1558. However, it lost many French possessions early on. For example, King John (1199-1216) lost Normandy and Anjou to France in 1204 and Aquitaine was confiscated in 1337 (precipitating the 100 Years War, 1337-1453).

${ }^{162}$ In 1618, the Thirty Years' War (1618-48) broke out. In 1620, James I's protestant son-in-law, Frederick V, Elector Palatine (1596-1632) was driven from Bohemia by the catholic emperor Ferdinand II. In 16201, James called a Parliament to finance a military expedition to support his son-in-law. The Commons granted inadequate subsides to finance any serious expedition in aid of Frederick, as well as made a Protestation to the King of 18th December 1621 which James tore out of the Journals of Parliament with his own hand. See Tanner, $n$ 13, pp 47-9. See also Keith, n 13, p 59.

${ }^{163}$ In the reign of Charles I (1625-49), in May 1625, some 10,000 soldiers were levied to be employed in the service of the Elector Palatine (see n 162). Parliament granted inadequate supplies and subsequent commissions of martial law issued by Charles led, in part, to the Petition of Right 1627. See McBain, n 58, p 29. In 1627-8, three naval expeditions were made to France, to La Rochelle, to encourage a major rebellion there, as part of the Thirty Years War (1618-48). They all failed, in part, because Parliament refused to grant adequate supplies. See Tanner, n 13, pp 54, 56, 59 .

${ }_{164}$ The Preamble to the Militia Act 1661 (13 Car st 1 c 6, rep) stated: 'The sole supreme government command and disposition of the militia
} 
they considered he might use it against them. ${ }^{165}$ The increasing of the size of this army by the catholic James II $(1685-8)^{166}$ precipitated - in considerable part - the Glorious Revolution of 1688 which fundamentally altered the situation.

Thus, from 1688, Britain had a standing army, financed by Parliament. This was a fundamental change to the situation existing in the past. The Bill of Rights 1688 also severely curtailed the Crown prerogative's to make war - in practice - since it stated:

The raising and keeping a standing army within this kingdom in time of peace unless it is with the consent of Parliament is against law. ${ }^{167}$

Further, from 1688, the control - and operation - of the military in England began to be placed on a strictly professional footing:

- Legislation, progressively, covered the field of military (martial) law; ${ }^{168}$

- Sovereigns no longer went into battle after $1743 ;{ }^{169}$

- Major Victorian reforms to the civil service and the military meant that sovereigns no longer interfered in military appointments. Offices and commissions were allocated on a professional basis, to the exclusion of patronage.

Today, the legal, and practical, justification for the Crown having a prerogative to make war and peace are wholly different to past ages. In particular, war cannot only be made by the Crown if money is allocated by Parliament. As Bradley notes:

The Crown may declare war, but Parliament alone may vote the supplies which enable war to be waged. $^{170}$

Further, the sovereign herself is no longer involved - even personally - in the making of war and peace. Anson, in 1935, stated:

The king, acting on the advice of his ministers, makes war and peace. ${ }^{171}$

Today, this statement records only the formal position since the reality is that the Government - with oversight and allocation of funds (supplies) by Parliament - makes war and peace and the role of the sovereign is a formal one only.

In conclusion, the Crown has the prerogative to make war and peace. However, it cannot do so, in practice, without funds being provided by Parliament.

and of all forces by sea and land and of all forts and places of strength is and by the laws of England ever was the undoubted right of his majesty and his royal predecessors Kings and Queens of England.' See also McBain, n 58, p 22.

${ }_{165}$ Although military tenure was abolished in 1660, Charles II retained a standing army of 5,000 men. See McBain, n 58, p 21. Keith, n 13, p 341 'In 1624 the Commons insisted on securing effective control over the funds they provided for the war...Both Charles I and Charles II had difficulty with Parliament on war issues.'

166 James II increased the size of the army to 15-20,000 men after the Monmouth rebellion of June-July 1685. E Samuel, An Historical Account of the British Army (London, W Clowes, 1816), p 168 'the military part of the feudal policy was formally abolished...at the Restoration [1660]; but the successive kings of England uninterruptedly exercised the right of commanding and legislating for the army, to the period of the Revolution [1668].' See also McBain, n 58, p 22.

167 Samuel, 166, p 149 'The declaration...made the parliament, in effect, a constituent power in the creation of the army; which, thenceforward, could not look to the Crown, as in foregoing seasons, as the sole author of its being.' See also McBain, n 58, p 22 and Chitty, $\mathrm{n} 10, \mathrm{p} 8$. Anson, n 12, vol 2, pt 1, pp 46-7 'The legislation of the reign of William III [1689-1702] had done two things in respect of the royal prerogative. It had defined the legal rights of the Crown, and it had taken from the Crown the means of controlling the interpretation of those rights... The first of these objects was attained when Parliament limited the king's life revenue to such sum as would barely enable him to conduct the business of government; when it legalized the standing army, and granted supplies for the national armed force every year, and for no more than a year.' Bradley, n 1, p 251 'The Bill of Rights 1689 prohibited the keeping of a standing army within the realm in time of peace without the consent of Parliament; thus the authority of Parliament is required for the maintenance of the army, the Royal Air Force and other forces serving on land. It has been pointed out that while the army and the RAF are now governed by statute 'the Royal Navy is still maintained by virtue of the prerogative'. He cites HC 422 (2003-4), para 18. (see n 3).

${ }^{168}$ See McBain, $\mathrm{n}$ 58, pp 21-3.

169 See $n 138$.

${ }^{170}$ Bradley, n 1, p 248. Bowyer (writing in 1841), n 11, p 215 'though the Crown has the power to declare war without the concurrence of the lords or commons, yet war cannot be carried on unless parliament will furnish the means.'

${ }^{171}$ Anson, n 11, vol 2, pt 1, p 136. Cf. Maitland, n 13, pp 423-4 (writing in 1908) 'the prerogative of making war and peace. This power...belongs to the king. Without the consent of parliament he can direct the invasion of a foreign country. Of course, Parliament has a certain check on this power. It might refuse to vote the necessary supplies. What is more to the purpose, it insists on knowing from the king's ministers what are the relations between the king and foreign governments, on having diplomatic correspondence laid before it, and so forth. Still it takes no act of parliament to make a war, even a war of aggression, and practically a ministry has a great deal of power as regards foreign affairs, and might even force a reluctant nation into a war from which it would be impossible to withdraw.' 


\section{Transferring the Crown Prerogative to Make War and Peace to Parliament}

It is asserted there are compelling reasons to transfer the Crown's prerogative to make war and peace to Parliament.

- Democracy. The making of war and peace in the UK, manifestly, has a dramatic on effect on every person living there. It is appropriate, therefore, that a decision to make war and peace, should only be taken after very great consideration and not just by the sovereign alone ${ }^{172}$ or by a few Government officials and bureaucrats purporting to act on behalf of the sovereign. Democracy is predicated on the freedom of individuals to express their opinions. Nowhere is this more important than where violence and 'legalised' killing (war) is to be permitted by the State;

- Executive Act. Making war and peace is, today, an executive act - not a personal one. It is that of the Government (the State) acting on behalf of the people, not one of a sovereign acting pursuant to advice. Thus, Parliament should determine the matter rather than the Queen or those purporting to act on her behalf;

- Sovereign's Role is Formal. The role of the sovereign in respect of military matters is now purely formal. She is no longer the head of a system of military tenure or required to furnish troops. Nor is she required (or has the ability) to command the armed forces or lead troops into battle. Further, the sovereign no longer issues orders to the military, nor sits in Parliament or in the British Cabinet, ${ }^{173}$ in order for her military commands to be carried into effect. Also, the Crown - in the wider sense of the administrative apparatus of government (including the Ministry of Defence) - is not subject to the control and will of the sovereign, but to the British Cabinet which - itself - is subject to Parliament. Thus, the ability of the sovereign to declare war and peace - while it still exists formally - no longer does so as a political, or administrative, reality.

As it is, since World War II (1939-45), the British government has generally avoided any official making (or declaring) of war and peace, in order to circumvent other legal difficulties. ${ }^{174}$ However, this does not make the Crown's prerogative to make 'war and peace' obsolete since it could still be declared by the Crown in the future. It is asserted that this Crown prerogative should be wholly transferred to Parliament who alone should exercise this right. ${ }^{175}$ What would be the problems with this? The making of peace is considered first, since the position is less complex.

\section{(a) $\underline{\text { Peace }}$}

Writing in 1935, Anson pointed out that - in modern times - making peace inevitably involved the execution of a peace treaty or other agreement. ${ }^{176}$ He also argued that Parliament should be involved given that:

- $\quad$ Peace may impose a pecuniary burden on the public; ${ }^{177}$

- There might be a cession of territory. ${ }^{178}$ In the past, the English courts had doubts as to the extent of the Crown prerogative to unilaterally cede territory. ${ }^{179}$ Anson regarded it as settled in his time that cession

\footnotetext{
172 In practice, this would simply not happen today since the sovereign is directed in all her political acts by her government, viz. the political party in power. If the sovereign sought to make war and peace unilaterally, this would, doubtless, provoke a constitutional crisis and the downfall of the monarchy.

${ }_{173}$ The last sovereign to preside in Cabinet was George III [1760-1820] in 1781.

174 Bradley, n 1, p 260 'In modern times, however, it has not been the practice to make a formal declaration of war before commencing military activity, as in the case of the invasion of Iraq in 2003.' At p 353 'No war has been formally declared since 1939 ... The Suez canal, the Falkland Islands, and the Gulf all received British armed forces on ministerial orders under the prerogative power to deploy those forces as the Crown thinks fit.' See also Crown Proceedings Act 1947, s 11.

${ }_{175}$ That is, legislation should make it clear that the Crown's prerogative to make war and peace is abolished and that Parliament shall make (and declare) war and peace.

${ }^{176}$ Anson, n 11, vol 2, p 137 'The prerogative of the Crown in making peace is so much involved in questions as to the prerogative in making treaties that the two must be dealt with together. Parliament has only indirect means of bringing war to a close, but it is hard to conceive of a peace concluded simply by a cessation of hostilities and mutual assurances of amity. Some engagement must be entered into, liabilities incurred, territory acquired or ceded.'

177 Ibid 'It would seem to follow from the general principles of our constitution that a treaty which lays a pecuniary burden on the people or which alters the law of the land needs Parliamentary sanction. If it were not so, the king, in virtue of this prerogative, might indirectly tax or legislate without consent of Parliament.'

${ }^{178}$ Ibid, 'The cession of territory is a matter 'in regard to which the practice of consulting Parliament has varied widely from time to time: but the tendency has been undoubtedly in the direction of obtaining the sanction of Parliament more regularly, and not merely by an address
} 
required Parliamentary approval - not least since it would likely change the nationality of subjects as well as the position on public debt. ${ }^{180}$

Whereas the involvement of Parliament in the past in any peace negotiations entered into by the Crown in which territory was ceded, varied, today, one would assert that Parliament would most certainly be - and should be involved. ${ }^{181}$ For example, if any British Overseas Territory were to be ceded, such matters should be by way of legislation. ${ }^{182}$

Thus, it is asserted legislation should now provide how peace should be made, in order to clarify the issue and to abolish the Crown's prerogative on this ${ }^{183}$ (the same applies in respect of the Crown's prerogative to make treaties in general).

\section{(b) War - Parliament Unable to Function}

If the Crown's prerogative to make war was abolished - and the right to make war was transferred to Parliament - the only problematic issue would seem to relate to Parliament's being unable to assemble, due to an emergency, in order to declare war. For example, suppose the Houses of Parliament were destroyed in a lightning strike by a foreign (or internal) aggressor and it was not otherwise able to assemble as quickly as required?

- Civil Contingencies Act 2004. Provision is made for this in the Civil Contingencies Act 2004. It deals with national emergencies and defines the same to include war that threatens 'serious damage' to the security of the UK. ${ }^{184}$ In such a situation - and where matters are urgent - the Act provides that her majesty in Council may make emergency regulations. ${ }^{185}$ However, in the case of an attack on Parliament there would not likely be time. The Act provides for an alternative in such an emergency. A 'senior Minister' of the Crown may make regulations. A senior minister comprises: (i) the prime minister; or (ii) any of her majesty's principal secretaries of state; or (iii) the commissioners of her majesty's treasury; ${ }^{186}$

- Regulations passed under the Act. Regulations may, inter alia, enable the Defence Council to authorise the deployment of her majesty's armed forces as well as make provision for facilitating the same. ${ }^{187}$ When such regulations are made a senior minister of the Crown (see above) shall - as soon as reasonably practicable - lay the regulations before Parliament. The same shall lapse within 7 days of the date of laying unless Parliament passes a resolution approving them. ${ }^{188}$

- No Provision for Sovereign to Act. It may be noted that this Act does not make any provision for the Queen to act in person. ${ }^{189}$ Nor for any proclamation by the same to be issued.

Thus, if the Crown prerogative to make war was abolished and making war was restricted to Parliament - and it was unable to meet immediately to make war - the Civil Contingencies Act would empower the executive to act. ${ }^{190}$ There would be no lacuna.

to the Crown, or a vote signifying approval, but making the treaty or convention conditional on the approval of Parliament and by the embodiment of the provisions relating to the cession in the schedule of a statute.'

${ }^{179}$ See Damodhar Gordhan v Deoram Kanji (1876) 1 AC 332. Also, Anson, n 11, vol 2, pp 137-41.

180 Anson, n 11, vol 2, p 140 'It may now be regarded as settled that cession of territory should be approved by Parliament, as in the case of session to Italy of Jubaland [Somalia] in 1927, and of the transfer of certain areas to Perak [in Malaysia] by the Dindings Agreement in 1934.'

${ }^{181}$ Indeed, in the past, exclusive Crown involvement - as well as that of the sovereign - meant that Parliament was often kept in the dark about the result. Sunkin, n 12, p 99 'The terms of the first Partition Treaty [of 1698] were arranged by William III [1689-1702], his ministers, Somers and Vernon, were given only a hurried and formal chance to approve the terms of peace with France which William concluded.' For the subsequent impeachment brought against Somers (John Somers, Baron Somers) and others, see GS McBain, Abolishing 'High Crimes and Misdemeanours' and the Criminal Processes of Impeachment and Attainder (2011) 85 ALJ 810-79 at p 831. Also, Holdsworth, n 9, vol 367.

${ }_{182}$ In the case of the cession of Hong Kong, legislation was utilised (Hong Kong Act 1985).

183 i.e. something to the effect that 'Peace shall be made by the entering into of a peace treaty or other agreement. It shall be approved by Parliament by way of statutory instrument.'

${ }_{184}$ Civil Contingencies Act 2004, ss $1 \& 19$ (definition of emergency).

185 Ibid, s 20(1). The conditions for the making of the same are, essentially, that: (a) an emergency has occurred (or is occurring or is about to occur); (b) it is necessary to make provision for preventing, controlling or mitigating it; (c) matters are urgent. See s 21.

${ }_{186}$ Ibid, s 20(3)(1) \& (m).

187 Ibid, s 22.

188 Ibid, $\mathrm{s} 27$.

189 This would not be appropriate anyway, since the Queen would have no access to the immediate political or military situation enabling her to issue any regulations. 


\section{(c) $\underline{\text { Limited Military Engagements }}$}

At present, there is a 'grey area'. The modern tendency is for the Crown (in fact, the Government) not to declare war as such ${ }^{191}$ but, rather, to engage in more limited military engagements - including those of a peace keeping nature. ${ }^{192}$ For example, the invasion of Iraq was the subject of a Parliamentary debate and there was no declaration of war as such. ${ }^{193}$ Bradley noted:

Although the invasion of Iraq in 2003 was the subject of a 'remarkable and extraordinary' debate and vote in Parliament, concern about the scope of the 'war powers' prerogative has led to demands for greater democratic control of its exercise. ${ }^{194}$ But it is unlikely that any government would agree to a formal requirement of parliamentary approval for military action, as has been proposed by a former Cabinet minister in a prominent private member's bill introduced in 2005. ${ }^{195}$

In a later House of Commons report, the general opinion of witnesses before the Committee issuing the report, was that the power of going to war was the most significant of the prerogative powers and that any military action overseas should require Parliamentary approval. ${ }^{196}$

- Draft Bill to Cover Armed Conflict. A suggested draft Bill presented to the Committee issuing the report provided that the armed forces should only take part in 'armed conflict'197 if their participation was approved by a resolution of each House of Parliament; ${ }^{198}$

- No Need for Resolution. The above would only not apply in the case of action taken by the armed forces 'in their immediate and personal self-defence. ${ }^{\text {, } 99}$ In such a case, resolutions were required to be obtained: (a) before those armed forces participated in armed conflict; or (b) if the government was of opinion that such participation was necessary as a matter of urgency before resolutions could be obtained, within 7 days from the beginning of participation. ${ }^{200}$

It is asserted this 'grey area' should be dealt with in legislation. Thus, the approval of Parliament should be required both in the case of war and in the case of any other military engagement abroad.

\section{(d) Conclusion}

One would assert today that, because:

- the Civil Contingencies Act 2004 covers emergencies, including war;

- Parliament's involvement is required to vote supplies for any war;

- the Crown - in the form of the sovereign in person - is no longer involved in war and peace,

\footnotetext{
${ }^{190}$ Likely, in the event of the Palace of Westminster being attacked, regulations would order the Defence Council to command the armed forces to take all steps to end the emergency (if necessary, attacking - with immediate effect - any aggressor). A declaration of war, as such, is not required in law in any case.

191 Sunkin, n 12, p 272 'it is difficult, particularly in legal terms, to draw a line between peacetime and war or armed conflict, since a declaration of war has become almost extinct since World War II [1939-45]. The conclusion must therefore be drawn that, in practical terms, little difference would exist between the exercise of these functions by the Secretary of State under the royal prerogative or by statute.'

${ }^{192}$ Ibid, p 270 'In constitutional theory...no consent of Parliament is required to send the British armed forces abroad to take part in an armed conflict, or to take part in a United Nations force or for humanitarian purposes. It has never been doubted that the Secretary of State has this power in relation to the regular forces under the royal prerogative but a similar power, in statutory form, was given in relation to the reserve forces in 1996.' At p 272 'There is no constraint upon the Crown, if it so desires, operating so as to place a section of the armed forces under the command of the police for a specific task or an allied power.'

${ }^{193}$ Ibid, p 272 noted that the Geneva Conventions 1949 (and additional Protocol I of 1977) - which are activated on the occurrence of an 'international armed conflict' - applied to the British involvement against Argentina in 1982 and Iraq in 1990-1 even though there was no declaration of war as such.

194 Bradley, n 1, p 260 (14 ${ }^{\text {th }}$ ed) who notes 'HC Deb, 18 March 2003, cols 760-911. The House of Commons voted by 412 to 149 to support a detailed government motion that authorised the 'use of all means necessary' to ensure the disarmament of Iraq's weapons of mass destruction. No such weapons have been found.'

195 Ibid. referring to Armed Forces (Parliamentary Approval for Participation in Armed Conflict) Bill 2005.

${ }^{196} \mathrm{HC}, \mathrm{n} 3$, p 9. See also pp 24-6.

197 This was defined to cover any use of force which gave rise (or might give rise) to a situation of armed conflict to which the Geneva Conventions of 1949 or the Additional Protocols of 1977 applied (see n 193). See c 5 (1).

${ }^{198}$ Ibid, n 3, p 35, c 5(2)

199 Ibid, c 5 (3).

${ }^{200}$ Ibid, c 5(4). If Parliament was prorogued (or dissolved) when such resolutions were needed, resolutions must be obtained as soon as practicable. Ibid, c 5(5).
} 
the making of war and peace should now be placed on a statutory footing.

- War and peace should only be made by Parliament, save where the Civil Contingencies Act 2004 otherwise applies. ${ }^{201}$ If not, confusion will likely prevail. The same should apply in the case of any other military engagements abroad;

- It is asserted that a transfer of the Crown prerogative to make war and peace to Parliament is essential in modern times in order to ensure that the democratic process is not undermined. Also, that a matter which affects the general public to a great degree (as well as public funds) is properly debated before being determined on. ${ }^{202}$

In conclusion, the Crown prerogative to make war and peace should be transferred to Parliament. In the case of peace, this is unlikely to be contentious. Further, it will help clarify matters. In the case of war, it is essential for the expansion of democracy. The position as to the declaration of war and peace is now considered.

\section{Crown Prerogative - To Declare War and Peace}

A subsidiary prerogative to the making of war and peace, is the Crown prerogative to declare war and peace. Is a declaration actually needed, however? This - and the method of declaring the same - has changed over time; in major part because of the changing nature of warfare. A distinction should also be drawn between: (a) civil war; (b) war against external enemies.

- Civil War. At least since 1305 until the last civil war in England and Scotland - the Jacobite rebellion of 1745 - the modus operandi of declaring war was the issue by the sovereign of a writ convoking his army (summonitio exercitus). Also, the raising of his standard (explicatio vexilli regis). ${ }^{203}$ The latter was important since anyone owing allegiance to the sovereign who then opposed the standard was guilty of high treason - levying war against the king in his realm (si home leve de guerre contre nre seignr le roi en son roialme) pursuant to the Treason Act 1351 (still extant). ${ }^{204}$ As to peace, in olden times, the sovereign proclaimed the same by means of a writ. ${ }^{205}$ This was also necessary vis-à-vis the application of martial law and its termination ${ }^{206}$ Today, civil war against the sovereign is extremely unlikely since she no longer has much power and there are no dynastic contenders to the throne. ${ }^{207}$ It is also pointless given that Parliament, since 1688, makes - and unmakes - sovereigns. ${ }^{208}$ Thus, unlike in times past, the defeat of the sovereign in battle or his capture, imprisonment, deposition etc would be of no legal effect in respect of his sovereignty unless Parliament chose to amend the Bill of Rights 1688 and the Act of Settlement $1700 .{ }^{209}$ For these - and other reasons - it has been asserted the crime of levying war should be abolished. ${ }^{210}$ Even if not so, in modern times, civil war would not be declared by the sovereign raising her standard on the battlefield (things have moved on a bit). Indeed, it is asserted that any civil war in the future in the UK would not need any formal declaration of war on the part of the Crown or Parliament (it is also not necessary for the purposes of the Treason Act 1351). As to the ending of such a civil war - as with the Jacobite rebellions of 1715 and 1745 - an Act of Parliament

\footnotetext{
${ }^{201}$ Cf. Sunkin, n 12, p 357 'while it would be unwise to insist on prior parliamentary approval for all military emergencies, a War Powers Act could be passed under which Parliament would have to be informed within a specified period of the armed forces being deployed overseas, and consent for that continued deployment would be required.'

${ }^{202}$ Even if the matter of making war is left with the Crown, there is no reason why peace should not be dealt with by legislation and be subject to the approval of Parliament at some stage.

${ }^{203}$ Hale, n 10, p 127 'Regularly the time of war then begins when the King by his writ styled summonitio exercitus hath prefixed the convening of his army, the usual badge whereof is explicatio vexilli [regis] or the setting up of his standard.' In making this statement Hale referred to the time of Henry III (1216-72).

${ }^{204}$ McBain, n 115, article (a).

${ }^{205}$ Hale, n 10, p 127 referred to writs in the time of Henry III (1216-72) after the battles of Lewes (1264) and Evesham (1265).

206 When martial law was imposed, the law on murder was relaxed in that combatants were generally permitted to be killed on the battlefield by the Crown or, possibly, shortly after the battle. However, this was much abused. By the time Hale wrote (in the 1640s) as to, legally, when war time (the 'time of war') existed was confused - given the changing nature of war and the fact that the courts tended to remain open since Westminster Hall itself was not generally threatened. Hale, n 10, p 129 'the evidences of a general time of war is the king's summons of his army, the shutting up all judicial proceedings and courts of justice, and other concurrent evidences of fact, though it hath been regularly the wisdom of the state to reduce this by act of Parliament to a certain time.' See also McBain, n 23, pp 25 \& 32, n 105.

207 Since 1745 there has been no serious challenge to the throne. The rebellions of Monmouth in 1685 and those of the Jacobites in 1715 and 1745 stood little chance of success and were relatively easily defeated. See McBain, n 115, article (a), pp 7-9.

${ }^{208}$ Thus, the Bill of Rights 1688 recognised William III (1688-1702) and Mary (1688-94) as sovereigns.

209 See $\mathrm{n}$ 208. The Act of Settlement 1700 specified for the Crown (failing any issue to William III [1689-1702] or Queen Anne [1702-14], which happened) to pass to Princess Sophia (the granddaughter of James I (1603-25)) and the 'heirs of her body being protestants.'

${ }^{210}$ McBain, n 115, article (a).
} 
would almost certainly deal with the aftermath as well as any Act of Grace (in which criminal punishments for levying civil war are reduced or pardoned); ${ }^{211}$

- External Enemies. Hale, writing in the 1640 s, noted that the sovereign could, by proclamation, make a foreign war or peace. ${ }^{212}$ Those who owed allegiance to the sovereign and who adhered (aided) the enemies of the sovereign committed high treason. ${ }^{213}$ Hale also noted that war was of two kinds: (a) war solemnly declared (bellum solemniter denuntiatum) $;{ }^{214}$ or (b) war not solemnly declared (bellum non solemniter denunciatum $)^{215}$ and that the former was the usual mode of proceeding. ${ }^{216}$ Hale also noted that: 'a state of war may be between two kingdoms without any proclamation or indication thereof or other matters of record to prove it. ${ }^{217}$

In early times, did war need to be declared, to make it legal under English law?

- Civil War. In the case of civil war - as previously noted - the raising of the standards warned those who opposed the sovereign that, from thenceforth, their 'diffidation' was treasonous'. ${ }^{218}$ No express declaration of war, as such, was required;

- War against Foreign Enemy. In the case of a foreign enemy, it seems clear that - jurisprudentially war could exist between England and another State although no declaration of war was made. Further, for the purposes of determining whether a subject had committed high treason ('adhering to the enemy'), the fact of war simply had to be proved in any trial of the same. It did not depend on whether any declaration had been made.

As war became more professional and 'civilised' there was a tendency in England and on the continent - in the case of any foreign war - to 'declare' war in some formal manner - although it was not a legal requirement as such. A rationale for this was subsequently supplied by English text writers, assisted by continental writers. Blackstone - in 1765 - cited the text of Grotius (1583-1645) De Jure Belli ac Pacis (On the Law of War and Peace, 1625$)^{219}$ in respect of the rationale for declaring war in a formal manner - and concluded:

in order to make a war completely effectual, it is necessary with us in England that it be publicly declared and duly proclaimed by the king's authority; and, then, all parts of both the contending nations, from the highest to the lowest, are bound by it. And, wherever the right resides of beginning a national war, there also must reside the right of ending it, or the power of making peace. ${ }^{220}$

However, Chitty, in 1820, came to a different conclusion. While citing Blackstone and Grotius, he stated:

Notwithstanding this, it seems that no public declaration, or formal proclamation of war is, by law, absolutely necessary to render it the duty of the king's subjects to consider and treat as an enemy, any foreign power against which war has in point of fact been resolved upon and commenced by his majesty. ${ }^{221}$

\footnotetext{
211 For the Acts of Grace in the case of the 1715 and 1745 rebellions, see McBain, n 115, article (a), p 8.

${ }^{212}$ Hale, n 10, p 173 'The king by proclamation... may make foreign war or peace...'

213 McBain, n 115, article (a), p 26 et seq. See also Hale, n 60, vol 1, p 159-70.

${ }^{214}$ Hale, n 60, vol 1, p 163 'when war is solemnly declared or proclaimed by our king against another prince or state.' For the distinction between solemn and not solemn made by Grotius, see H Grotius, The Rights of War and Peace (published 1625, Liberty Fund translation, 2005), p 250.

215 Ibid 'when two nations slip suddenly into a war without any solemnity.' Hale gives, as an example, the first Anglo-Dutch war [1652-4] 'yet it began barely upon general letters of marque.' Also, the war between Spain and England at the time of the Spanish Amada in 1588, 'yet there was no war declared or proclaimed between the two crowns.'

216 Ibid, p 163.

217 Ibid, p 164. Hale also noted that, for the purposes of the Treason Act 1351 and the crime of adhering - whether there was a war or not between England and a foreign State (power) - was a matter of fact to be determined by a jury. Ibid. See also Bacon, n 6, vol 6, p 532. For a certificate in modern times of a Secretary of State about the existence of a state of war, see $R v$ Bottrill [1947] 1 KB 41. Also, Sunkin, $\mathrm{n} 12$, $\mathrm{p}$ 359

${ }_{218}$ McBain, n 115, article (a), p 4, n 41.

219 Blackstone, n 8, vol 1, p 250, 'And the reason which is given by Grotius, why according to the law of nations a denunciation of war ought always to precede the actual commencement of hostilities, is not so much that the enemy may be put upon his guard...but that it may be certainly clear that the war is not undertaken by private persons, but by the will of the whole community; whose right of willing is in this case transferred to the supreme magistrate by the fundamental laws of society.' See also Grotius, n $214, \mathrm{p} 1252$.

${ }^{220}$ Ibid, vol 1, p 250. Blackstone continues 'And the same check of parliamentary impeachment, for improper or inglorious conduct, in beginning, conducting, or concluding a national war, is in general sufficient to restrain the ministers of the crown from a wanton or injurious exertion of this great prerogative.' This was not necessarily true and the last case of impeachment was in 1806 (the unsuccessful impeachment of Lord Melville). See also McBain, n 181, p 826.

${ }_{221}$ Chitty, n 10, p 44. Halsbury, n 1, para 809 'formal declaration or actual hostilities.' Cf. E de Vattel, The Law of Nations (Le Droit de Gens, 1758, Liberty Fund, translation 2008) (writing in 1758), p 502 'It is necessary that the declaration of war be known to the state against whom it is made. This is all which the natural law of nations requires.' His rationale was that a declaration might then lead nations to resolve their
} 
It seems clear Chitty is correct in law. No declaration need be given. Also,

- In the past the right to declare war and peace belonged to the sovereign in person. Today, this tends to be phrased in legal texts as being the Crown's right - reference to the 'Crown' being the same in a political - and not a personal - sense, ${ }^{222}$

- Today, it is dubious whether the sovereign could unilaterally declare war or peace (and, if she did, whether anyone would take any notice);

- A declaration of war is equal to an Act of Parliament - as has been noted by the courts. ${ }^{223}$

In conclusion, a declaration of war or peace is not legally necessary under English law, although, in practice, it often occurs.

\section{Declaring War and Peace to Pass to Parliament}

In light of the statements made in $\mathbf{8}$ and $\mathbf{9}$, it is asserted that the Crown's prerogative to declare war and peace should be abolished. The same should now be exercised by Parliament alone. In respect of this, a declaration of peace is considered first, since it is simpler.

\section{(a) Declaration of Peace}

Halsbury states:

Termination of war is usually effected by a treaty of peace and announced to the nation by proclamation or Order in Council [i.e. by way of a Statutory Instrument]. ${ }^{224}$ Proclamations and Orders in Council of this nature were made after the $1939-45$ war, as also after the 1914-18 war. $^{225}$

In the case of any future peace treaty, it is likely the process adopted in World War II (1939-45) by the UK would be followed.

- This was usually via the signing of a peace treaty. However, sometimes, another form of agreement was utilised. Legislation then gave power to make an Order in Council to bring the treaty into effect; ${ }^{226}$

- Given that legislation provided for 'peace' to be brought into effect, this modern making of peace was not a direct exercise of the Crown prerogative as such.

Today, there would seem to be no good reason why Parliament - in modern times - should not have the sole capacity to declare peace. And for legislation to effect the same pursuant to a peace treaty. ${ }^{227}$ Thus, the Crown prerogative in this respect should be abolished.

In conclusion, legislation should provide for peace to be declared by means of a peace treaty or other agreement and for the same to be brought into effect by subordinate legislation (an order in council). The Crown prerogative to declare peace should be abolished.

differences prior to actual war. Also, to fix the date of rights which then subjects will acquire, such as the right to prize. He noted, $\mathrm{p} 503$, that - in the treaty of Aix-la-Chapelle (in 1748), between France and Spain (on one side) and England (on the other) - it was agreed that all prizes taken prior to the declaration of war should be restored.' Vattel also noted that no declaration was needed in the case of a State which was attacked and only waged defensive war, ibid, p 503. He also indicated circumstances in which a declaration could be omitted in the case of an offensive war. Ibid, pp 503-4.

${ }^{222}$ Vincenzi, n 12, p 114 'It is...the Crown's exclusive decision whether or not to declare war.'

223 Ibid, p 114. See Esposito v Bowden (1856) 7 El \& B1 763 (119 ER 1430).

${ }^{224}$ Halsbury, n 1, para 4 'It is usual on such occasions to publish notices as to the signing and ratification of the treaty of peace in the London Gazette, and after ratification the fact that peace is established is usually announced by proclamation. In the 20 th century, war was not necessarily ended by a peace treaty. Halsbury, n 1, para 810 cites an agreement with Thailand on 1 January 1946 (Cmd 8140 ) as an agreement not amounting to a peace treaty.

225 Ibid.

226 Halsbury, n 1, para 810 'Proclamations and Orders in Council of this nature were made after the 1939-45 war, as also after the 1918 war'. In the case of World War I [1914-18] the Termination of the Present War (Definition) Act 1918 gave the power to declare the date of the termination of the war by Order in Council (which occurred). In the case of World War II [1939-45], Orders in Council and proclamations were used.

227 See n 183. 


\section{(b) Declaration of War}

In modern times, the idea that the sovereign could, personally, declare war (whether under the great seal or by proclamation) is not acceptable - not least since she is not in any real control of the armed forces nor of Government. Further, the idea that bureaucrats should be able to do the same in the name of the Crown, on her behalf, is also unacceptable. Thus, war should be declared in - and by - Parliament and one would assert that the appropriate mode would be (as in the case of World War II) that it is 'declared' by the prime minister. ${ }^{228}$ A draft Bill prepared for a House of Commons committee (see 8(c)) stated:

No declaration of war shall be made on behalf of the United Kingdom unless that declaration has been approved by resolution of each house of Parliament. ${ }^{229}$

One would agree with this, save that, also, the declaration and the time of commencement of war should be later evidenced in legislation (whether primary or secondary).

In conclusion, legislation should provide for the manner of declaring war and peace. The Crown prerogative to declare war and peace should be abolished.

\section{Benefits of Abolishing Crown Prerogative Re War and Peace}

If the Crown prerogative to make - as well as to declare - war and peace were abolished and matters were placed on a statutory footing, this would bring considerable benefits.

- It would remove a mass of old caselaw, legal texts and fragmentary legislation. It would also remove a great deal of obscurity and clarify an area of law which - it is important - should be very straightforward and intelligible;

- Further, it would help remove the historical tendency of the Crown in times of war to encroach (often severely) on human liberties, when this was not required. This was often so through the failure of legislation in war time to expressly deal with matters.

In respect of the latter, Halsbury states:

In time of war and in matters relating to war the Crown enjoys generally a somewhat wider latitude in the exercise of the prerogative than in time of peace, for in such matters more stringent measures than are ordinarily allowed by the common or statute law are frequently rendered necessary for the public safety or for the restoration of peace and good order. Thus, it is possible that the exercise of martial law is to some extent permissible in time of war, and various prerogatives relating to the relations between British subjects and those of foreign countries are allowed to the Crown in time of war. Presumptions in favour of the liberty and property of the subject, which are usually of great effect in interpreting statutes in time of peace, become relatively weak in time of war when the safety of the realm is in danger. ${ }^{230}$

As to this:

- It is asserted that martial law should be abolished (see 12);

- The latitude accorded to the Crown in wartime was - almost always - unnecessary in hindsight and counter-productive in practice. It failed to achieve its goal, but it did materially subvert fundamental principles of justice and freedom; ${ }^{231}$

- If the Crown prerogative on these matters of war and peace (including in respect of martial law) is abolished, legislation will then stipulate the precise position (if required) and it will be left to the courts

\footnotetext{
228 The fact that reference is made to a declaration of war - as opposed to a proclamation of war - indicates the true position today. That it is not, in reality, an act of the Crown.

${ }^{229} \mathrm{HC}, \mathrm{n} 3, \mathrm{p} 36$

${ }^{230}$ Halsbury, n 1 , para 811 .

231 Halsbury refers to $R v$ Halliday [1917] AC 260 at 270; Ronnfeldt $v$ Phillips (1918) 35 TLR 46, Hudson's Bay Co v Maclay (1920) 36 TLR 469 at 475 and Liversidge $v$ Anderson (1942) AC 206. In historical hindsight, these are cases where the Crown prerogative was not wisely exercised and was not necessary.
} 
- applying the usual judicial canons of construction - to determine whether any 'latitude' is appropriate having regard to the specific wording of the relevant Act. This can only be much better, legally. Further, it will result in a lesser subversion of democracy and the rule of law.

Halsbury also refers to the fact that:

The counter-maxim salus populi suprema lex ('for the safety of the people is the paramount law') is applied as a corrective. ${ }^{232}$

This maxim from Roman law $^{233}$ - as well as another said to have been contained in the final paragraph of the Roman Twelve Tables -

Et silent leges inter arma ('and amidst the clash of arms the laws are silent') $)^{234}$

was applied - as in the case of martial law - for the undertaking of acts by the Crown (Government) which were not justified in strict law but which were required (it was asserted at the time) in order to preserve the community as a whole from complete disaster or annihilation.

- However, in hindsight, when the law was discarded and military force allowed to prevail in a civilian context, the results were invariably counter-productive;

- Indeed, globally, the great lesson of the last two centuries has been that - if the law is not allowed to prevail in all circumstances - human rights abuses on a gigantic scale, result.

In modern times, there is no need for such a wide latitude to be permitted to the Government without legislation even in war time - it being a discretion which can easily be abused and become tyrannical. After all, there is now a professional army, which is regulated by military law; and there are clear rules of military engagement. Further, in the case of civilians, they should not be conscripted (impressed) or made to serve under military law or be tried and condemned by military tribunals or be obliged to take up arms unless legislation clearly and expressly so provides.

In conclusion, the Crown prerogatives to make war and peace - as well as to declare war and peace - should be transferred to Parliament and be specified in legislation.

\section{Obsolete Subsidiary Military Prerogatives}

As well as the Crown prerogative to make war and peace, Halsbury refers to certain subordinate prerogatives of a military nature. These will be dealt with briefly, since it has been asserted in other articles that these are obsolete.

- Impressment - Navy \& Army. ${ }^{235}$ Service in the king's navy prior to the establishment of the royal navy was grim with low pay, quality of life and life expectancy. As a result, in medieval times, the Crown asserted a prerogative to impress (i.e. forcibly recruit) ${ }^{236}$ mariners into the navy, for his majesty's service, since no one wanted to serve voluntarily. This continued until 1814 when impressment was abandoned and never re-assumed. A Royal Commission report in 1859 on the Manning of the Navy stated that naval impressment could no longer be successfully enforced. In any case impressment was subject to many exceptions. ${ }^{237}$ Today, impressment would not be necessary, since there is a professional royal navy (indeed, there is a surfeit of men willing to serve). Also, pay and

\footnotetext{
${ }^{232}$ Halsbury, n 1, para 811. See also Fuller, n 60, p 145.

${ }^{233}$ MT Cicero, De Legibus, bk 3, pt 3, sub 8 ('ollis salus populi suprema lex esto'). Also translated as 'Let the good of the people be the supreme law.'

${ }^{234}$ McBain, n 58 p 52. See also MT Cicero, Pro Milone (ed FH Colson, Bristol Classical Press), 'silent enim leges inter arma.' (For laws are silent when arms are raised, and do not expect themselves to be waited for, when he who waits will have to suffer an undeserved penalty before he can exact a merited punishment.').

${ }^{235}$ See McBain, n 23, pp 18-20. Also, Vincenzi, n 12, p 25 and De Smith \& Brazier, n 13, p 136 (power to impress 'withered away'). See also Chalmers \& Asquith, n 12, pp 160-1; Feilden, n 12, p 318 and Amos, n 12, pp 123-4.

${ }^{236}$ Maitland, n 13, p 461 thought the word 'impressment' - which suggests force and restraint - probably had a different origin, deriving from the Latin 'impraestare', to advance money or pay. One would suggest the word was synonymous with (or similar to) the word 'indenture' where men entered into a contract to serve the Crown for an agreed sum. Thus, the word 'impressment' - in itself - was not designed to have a negative connotation.

${ }^{237}$ In practice, impressment was of men in the merchant marine, aged 18-55. By 1769, the satirist Junius (probably reflecting general public opinion) asserted, $\mathrm{n} 82$, vol 2, p 178, that - if others apart from seamen were impressed - it was a 'gross abuse'. Probably, citizens of London could not be impressed in any case. See McBain, n 23, p 58, n 44. However, aliens can be impressed - even in peace time - as can British subjects. Chitty, n 10, p 47. See also CM Clode, The Military Forces of the Crown (William Clowes, London), vol 2, ch 15.
} 
conditions - the basis for resorting to impressment - are now good. Finally, impressing men for the navy by relying on the Crown prerogative would almost certainly be politically - and practically unacceptable. $^{238}$ A Crown prerogative to impress for the army is even more uncertain and controversial. In any case, from early times, legislation was invariably resorted to. Impressment for the army ended in $1780 .^{239}$ In the case of World War I (1914-18) and II (1939-45), conscription for both the army and the navy was effected pursuant to legislation. ${ }^{240}$ In conclusion, any Crown prerogative to impress for the army or the navy is unnecessary. It is asserted that it should be abolished; ${ }^{241}$

- Letters of Marque \& Reprisal. ${ }^{242}$ These grants by the Crown comprised a form of State licensed privateering (as opposed to piracy). Thus, the Crown encouraged private ships owned by subjects to wage war on enemy shipping in times when the Crown had few ships. ${ }^{243}$ This system of marque and reprisal was obsolete by 1815 and the Declaration of Paris respecting Maritime Law of 16 April 1856 renounced privateering, an essential aspect of which were such letters of marque and reprisal. ${ }^{244}$ This Crown prerogative is long obsolete. It is asserted that it should be abolished;

- Letters of Safe Conduct. The Crown prerogative to issue letters of safe conduct preceded modern passports and letters of safe conduct were obsolete by 1836. The purpose of letters of safe conduct issued at the command of the sovereign - was, principally, to permit foreign merchants to be able to enter the realm without the risk of their merchandise being seized (especially if their country was at war with the Crown). Letters of safe conduct were also given to visiting diplomats and - more rarely - to foreign sovereigns visiting England. Today, the entry, and exit, of foreigners into the UK (including in wartime) has long been governed by legislation and by passports. Thus, letters of conduct are obsolete, as is the prerogative to issue the same, ${ }^{245}$

- $\quad$ Prohibit Subjects from Leaving the Realm or to Order Return. The Crown prerogative to prohibit subjects from leaving the realm was based on allegiance and, jurisprudentially, it was justified on the basis of the need to retain men - and expertise - for war and defence. However, in olden times, it was, in practice, often used to prohibit important religious leaders (or magnates) from quitting the realm; ${ }^{246}$ as

\footnotetext{
${ }^{238}$ The Crown prerogative is based on allegiance (although, anomalously, foreign mariners were impressed, see McBain, n 58 p 19, n 44). Proving allegiance could be difficult and the basis for asserting an age range (18-55) would almost certainly require legislation today (55 would be too old for the modern navy in any case). In times past, the order to impress was given in a warrant (patent) from the admiralty board. It was grounded on an order by the sovereign in council. Today, patents of the admiralty board no longer exist, nor the office of lord high admiral (save as a sinecure, in the case of Prince Philip). See also Vincenzi, n 12, p 20, n 50; Anson, n 12, vol 2, p 217 (writing in 1935) and Maitland, $\mathrm{n}$ 13, pp 461-2.

${ }_{239}$ See McBain, n 23, p 19. For a proclamation ordering impressment into the army for foreign service in 1588 (at the time of the Armada) see Holdsworth, n 9, vol 4, p 299. See also 35 Eliz c 4 (1592) and PL Hughes \& JF Larkin, Tudor Royal Proclamations (New Haven and London, Yale UP, 1969), vol 3, pp 26-7 (proclamation of 4 October 1588, Ordering Soldiers to Report for Embarkation to the Low Countries (Netherlands)). See also Holdsworth, n 9, vol 10, p 377. At p 318, 'in 1641 Parliament had declared that the Crown had no power to impress men for the army.' Bowyer, n 11, p 663 maintained that legislation, 4 \& 5 Phil \& Mary, c 3 (1557), sanctioned the impressment of soldiers out of the realm. See also McBain, n 60, p 54 and Clode, n 237, vol 1, pp 26-7 (referring to 16 Car 1 c 28).

${ }^{240}$ See McBain, n 60, p 54. In World War I (1914-18) and II (1939-45), the age for men was 18-41. In the case of national service, it was 17-21. Ibid, n 295. Today, the armed forces still recruit 16 and 17 year olds (unlike most other countries) and there is debate whether this is too young. The use of legislation for conscription post 1688 was usual (e.g. conscription of paupers for the army in the time of Queen Anne (1702-14) and impressment for the army at the time of the 1745 rebellion, see Thomson, n 13, pp 297 \& 424).

${ }^{241}$ Also - given the nature of modern warfare - the last thing the navy or armed forces would want are large numbers of men with no military experience or inclination. Everything is now hi-tech where manpower is far less valuable that rockets, drones, missiles, weapons etc. It may be noted that regulations made under the Civil Contingencies Act 2004 may not 'require a person, or enable a person to be required, to provide military service.' See ibid, s 23(3). See also Halsbury, n 1, para 370 n 3 'the power to impress men into the navy, have ceased to be exercised and could hardly be revived.'

${ }^{242}$ See also Chitty, $\mathrm{n} \mathrm{10,} \mathrm{pp} \mathrm{40-4.} \mathrm{For} \mathrm{the} \mathrm{position} \mathrm{by} \mathrm{1841,} \mathrm{see} \mathrm{Bowyer,} \mathrm{n} \mathrm{11,} \mathrm{pp} \mathrm{223-4.} \mathrm{Reprisal} \mathrm{was} \mathrm{not} \mathrm{necessarily} \mathrm{limited} \mathrm{to} \mathrm{seizing} \mathrm{the}$ ships (or the subjects) of a State against whom the Crown permitted reprisal. However, in England, historically, this tended to be the preferred method. See a useful analysis of reprisal in Vattel, $n$ 221, pp 462-7. In particular, it adverted to the grant of reprisals by the English Crown to the knights of Malta in 1662 against the United [Dutch] Provinces as not being (as asserted by the Dutch) according to the law of nations, since reprisals could only be granted to subjects and not to third parties (foreigners). It seems that the English Crown accepted this and ordered the release of ships seized. As to the extent of the asserted prerogative see Bacon, n 148, p 179 'The king hath power to grant his letter of mart and reprisal for remedy to his subjects upon foreign wrongs at his pleasure.'

${ }^{243}$ Prior to the establishment of a royal navy in the time of Henry VIII (1509-47), the Crown had few ships (Elizabeth I (1558-1603) had just 33 ships) and often relied on private ones - including those supplied by mariners from the Cinque Ports. The latter were unreliable and often looted not just enemy shipping but any shipping, including those of their countrymen. See generally, KME Murray, The Constitutional History of the Cinque Ports. (1935, Manchester University Press).

${ }^{244}$ See McBain, n 23, p 23. Also, Holdsworth, n 9, vol 10, pp 374-5.

${ }_{245}$ Ibid, pp 23-6. See also Holdsworth, n 9, vol 10, pp 375-6, 390-3. Bowyer, n 11, p 226 (writing in 1841) 'passports are now more usually obtained [than letters of safe conduct].'

${ }^{246}$ This was during power struggles between English sovereigns and the popes, involving questions as to whom clerics owed their principal allegiance.
} 
well those who might commit treason. ${ }^{247}$ It was especially resorted to in war time. From early times, this prerogative was supplemented (or effectively superceded) by legislation and, in the case of World War I (1914-8) and II (1939-45), legislation was employed instead. Today, this prerogative is not required. It is also a restriction on human rights and is, likely, not enforceable. The same applies to the Crown prerogative to order the return of a subject to the realm. ${ }^{248}$ It is asserted that both these Crown prerogatives should be abolished;

- Dig for Saltpetre for Gunpowder. A Crown prerogative to dig on the land of a subject for saltpetre (to make gunpowder) is palpably obsolete today, since saltpetre is no longer used for gunpowder. Also, it was only utilised, in the main, in the period 1589-1688 when the Crown had difficulty sourcing supplies of saltpetre from abroad. ${ }^{249}$ The legal basis for asserting such a prerogative in any case is weak. ${ }^{250}$ This $^{2}$ Crown prerogative should be abolished;

- Martial Law. ${ }^{251}$ Martial law had many meanings. However, today, the concept of 'martial law' is only legally coherent when it refers to a Crown prerogative to subject civilians to military law - including their trial, and punishment, before a military tribunal. In past times, the purpose of implementing martial law was to subject civilians to harsher military punishments than otherwise prevailed at common law (including the death penalty, flogging, etc). Such punishments no longer apply today. Further, the Petition of Right 1627 (still extant) precludes the imposition of martial law in peace time. Thus, today, martial law could apply, in any case, only in war time and where the courts are either closed or incapable of effectively operating. ${ }^{252}$ However, this situation is now covered by the Civil Contingencies Act 2004 which precludes the submission of civilians to military tribunals. Thus, the rationale - and justification - for martial law has gone and, not having applied in the UK since, at least $1688,{ }^{253}$ it is obsolete. It should be abolished. If martial law was ever required in the future (that is, the need to subject civilians to military law) then it should be effected by legislation;

- $\quad$ Billet. The Crown had a prerogative to be able to billet army and naval personnel on the general public and in common inns. The Petition of Right 1627, s 8 (still extant) sought to prohibit the former. However, this prerogative is unnecessary and should be abolished since the power to billet lies with the government (Ministry of Defence) and Parliament. Provisions empowering the proper authorities of the

\footnotetext{
${ }^{247}$ See McBain, n 23, pp 26-32. See, for example, the Constitutions of Clarendon 1166 (rep). It provided that archbishops, bishops and priests were not permitted to leave the realm without the sovereign's permission. It is likely this prohibition existed at common law prior to the Constitutions. Henry II razed three castles of the bishop of Winchester in 1155 on his quitting the realm without licence, see Roger of Wendover, Flowers of History (trans JA Giles, London, Henry G Bohn, 1849), vol 1, p 528.

${ }^{248}$ Ibid, pp 33-5. These prerogatives can only apply to subjects. See Holdsworth, n 9, vol 6, p 54, n 10 quoting Whitelocke in 2 ST 514 in 1610 founding the prerogative to prohibit on the 'common good of the realm' See also Bowyer, n 11, pp 233-4 and Finch, n 69, pp 76-7 'For every man is bound of common right to defend the king and the realm.' It may be noted that regulations passed under the Civil Contingencies Act 2004 cannot, see s 22 (3) (d) 'prohibit, or enable the prohibition of, movement to or from a specified place' or (e) 'require, or enable the requirement of, movement to or from a specified place.' See also De Smith \& Brazier, n 13, p 136.

${ }^{249}$ See Holdsworth, n 9, vol 6, p 305.

${ }^{250}$ King's Prerogative in Saltpetre (1606) 12 Co Rep 12 (77 ER 1294). The basis that it was for the defence of the realm could be used to assert a right of the Crown to dig on the land of a subject for whatever reason if they might be able to assert that it was required for the defence of the realm. See also $A-G v$ De Keyser's Royal Hotel [1920] AC 508 at p 571 per Lord Parmoor 'The Saltpetre Case was decided in 1606 , at a time when the claim to act by royal prerogative was carried to an extreme length...The saltpetre was taken under the right of purveyance, and payment was made...Purveyances were abolished in 1660 by 12 Car 2 c 4 [rep]. The volume of extracts from public records made for the purposes of this case by the record agent contains warrants for the searching of saltpetre, but in every case on the payment of rent or compensation.'

${ }^{251}$ See McBain, n 23. See also Keir \& Lawson, n 12, pp 174-9, $217-50$ (however, this analysis - given in 1979 - does not consider the Civil Contingencies Act 2004; nor contains a full review of early law). There seems little doubt that, originally, the power of the sovereign and supreme military commander, in battle was modelled on Roman law. E Gibbon, The History of the Decline and Fall of the Roman Empire (ed W Smith, London, John Murray, 1855), p 109 'The most sacred rights of freedom, confirmed by the Porcian and Sempronian laws, were suspended by the military engagement. In his camp the general exercised an absolute power of life and death; his jurisdiction was not confirmed by any forms of trial or rules of proceeding, and the execution of the sentence was immediate and without appeal.' See also Clode, n 237, vol 2, ch 18 and Chalmers \& Asquith, n 12, pp 363-70. The Law Magazine, vols 45 (1851), p 70 \& 48 (1854), p 211 contains articles on martial law. So too the Law Magazine and Review, vols 10, pp 354 \& 21, p 222.

${ }^{252}$ There was a 'grey' área in respect of major riots and rebellion, which the Crown exploited. Today, riots are covered by legislation and rebellion specifically against the sovereign (or to effect changes in legislation) would be restricted to the Treason Act 1351 (and the Treason Felony Act 1848).

${ }^{253}$ Martial law was used in the colonies post 1688, to disastrous effect. However, it seems to have ended by 1865 (in Jamaica), to be re-suscitated in the Boer War (1902) and in Ireland (1916-20). In many cases where it was used in the colonies post-1688, however, it was superceded by legislation due to the uncertainty of the prerogative and excesses that derived from it. For a useful statement as to the nature of martial law by 1940, see AB Keith, The Constitution of England from Queen Victoria to George VI (Macmillan \& Co, London, 1940), vol 2, pp 389-93.
} 
regular forces (or of the regular air force) to issue billeting requisitions are contained in the Army Act 1955 and the Air Force Act 1955. ${ }^{254}$

In conclusion, various obsolete Crown prerogatives of a military nature should be abolished, viz. to (i) impress subjects for the navy; (ii) issue letters of reprisal and marque; (iii) issue letters of safe conduct; (iv) prohibit subjects from leaving the realm; (v) order subjects to return to the realm; (vi) dig for saltpetre (for gunpowder); (vii) impose martial law.

\section{Fortifications on a Subject's Land}

The Crown prerogative to erect fortifications on a subject's land in war time is related to the legal prohibition on subjects erecting fortifications in peace time.

\section{(a) Subject Erecting Fortifications - Peace Time}

Without a permission (licence) from the sovereign no subject can build a military castle or fortress. Coke stated: no subject can build a castle or house of strength imbattled, etc. or other fortress defensible...without the licence of the king, for the danger which might ensue, if every man at his pleasure might do it. And they be called imbattlements, because they are defences against battles in assaults. ${ }^{255}$

This prohibition is very old since Britton (c. 1290) states:

let it be inquired what persons have built castles or fortlets or houses of stone, crenelated and defensible; and let those who have so done be summoned to come and answer, and show if they have any license from us or our ancestors, for erecting or repairing such fortlets, and if they cannot produce any such license, let them be taken into our hand, either to be held by us or pulled down, according to our pleasure. $^{256}$

Britton wrote in the reign of Edward I (1272-1307). However, this common law prohibition requiring the licence of the sovereign to build castles is much earlier - existing at least in the time of Henry I (1100-35) since his laws provide:

The following place a man in the king's mercy...construction of fortifications without permission [castellatio sine licencia]. ${ }^{257}$

Further, in the reigns of Stephen (1135-54) ${ }^{258}$ and Henry II (1154-89), ${ }^{259}$ many unauthorised (adulterine) castles were destroyed. ${ }^{260}$ Such a prohibition was understandable in those times. It was to protect the sovereign against

\footnotetext{
254 See GS McBain, Modernising the Monarchy in Legal Terms - Part 2. (2011) KLJ, vol 22(1), p 98. It may be noted that the billeting provisions in the Petition of Right 1627 were annually suspended in any case. For an early statement as to the limit on the Crown prerogative see J Fortescue, On the Laws and Governance of England (Cambridge UP, 1997), pp 51-2 'In the realm of England, no one billets himself in another's house against his master's will, unless in public hostelries, where even so he will pay in full for all that he has expended there, before his departure.' See also 31 Car II c $1 \mathrm{~s} 32$ (illegal to billet on citizen without their consent). For continued billeting on citizens (albeit illegal) in the time of James II (1685-9), see Clode, n 237, vol 1, pp 80-1. For Commons debates on billeting see Fuller, n 60, pp 19, 21, 47-9, $52,176$.

${ }^{255}$ Coke, n 7, vol 1, 5a. Blackstone, n 8, vol 1, p 255 'all lands were formerly subject to a tax, for building of castles whenever the king thought proper.' He also notes that, in Anglo-Saxon times, lands were subject to the trinoda necessitas, one of which was the construction of fortifications (arcis constructio).

${ }^{256}$ Britton (ed FM Nichols \& SE Baldwin, John Byrne \& Co, 1901), pp 64-5.

257 Leges Henrici Primi (OUP, 1972), p 117. See also p 109 'These are the jurisdictinal rights which the king of England has in his land solely and over all men...fortifications consisting of three walls.'

${ }^{258}$ The ODNB, n 60, p 411, notes that, in 1139, the king required the bishops of Lincoln and Ely to surrender their castles. And at a Council subsequently convened in August 1139 the king 'and his supporters...sustained the main point of their case that in time of war the Crown should have the right to garrison strategic fortresses'. See also Roger of Wendover, n 247, vol 1, pp 490-1. Further, at a peace settlement in November 1153 between the king and the future Henry II (1154-89), see p 414, 'It was agreed also that many recently built castles, the most visible sign of the civil war, would be destroyed.'

${ }^{259}$ It was said by a chronicler - Robert of Torigny (Torigni, 1110-86) - that as many as 1115 castles had been built during the Civil War of 1139-54. However, elsewhere, he refers to 126 castles. See J Bradbury, Stephen and Matilda: The Civil War of 1139-53 (Stroud, UK. The History Press). See also Capitula Escaetrie (temp incert. Articles of the Office of Escheator), 'Also of castles and embattled houses, pillories, and tumbrels erected without the king's licence.' See also C Coulson, The Castles of the Anarchy in E King (ed), The Anarchy of King Stephen's Reign (OUP, 1994); Blackstone, n 8, vol 1, p 255, Roger of Wendover, 247, vol 1, p 510.

${ }^{260}$ Noted by Blackstone, $\mathrm{n} 8$, vol 1, p 255. Adulterine castles were those built during the 12th century without royal approval, particularly during the Civil war of Anarchy between 1139-54.
} 
powerful magnates since a fortified castle could hold out against him and be a threat to his power. Coke maintained that Magna Carta (1215) did not contain an express prohibition since castles could only be erected by the sovereign or pursuant to statute. ${ }^{261}$

- Coke refers 'castles', 'houses of strength' and to 'fortresses'. It is asserted these terms are synonymous. ${ }^{262}$ He also referred to 'bulwarks' (earth ramparts); ${ }^{263}$

- Historically, castles developed rapidly from the $9^{\text {th }}$ century. By the $11^{\text {th }}$ century, this type of private fortress - known as the 'motte (mound) and bailey' castle - spread over Western Europe. ${ }^{264}$ However, the development of the use of firearms was so rapid in the $15^{\text {th }}$ and $16^{\text {th }}$ centuries as to require a radical change in military architecture, such that the age of the medieval castle came to an end. ${ }^{265}$ The system of the Crown licensing castles also died out.

By the time Coke was encapsulating in writing this common law prohibition against a subject building a castle it was no longer necessary. The sovereign was not threatened by powerful magnates hiding behind the walls of their castles. When Chitty wrote (in 1820), the common law prohibition on a subject building castles and bulwarks was re-stated in more general terms, so as to cover any type of fortification. However, this really is an unwarranted extrapolation of the common law position without any statutory, or case, support. ${ }^{266}$ Further, the emphasis switched from a prohibition on a subject erecting fortifications without a licence from the Crown to an emphasis on the Crown having the sole prerogative. Thus, Chitty stated:

the king is solely entitled to erect, fortify, and govern forts and other places of strength, within his dominions. $^{267}$

Chitty cited the recital to the Militia Act $1661^{268}$ - as well as some other legislation - all of which has been repealed. ${ }^{269}$ Given the repeal of such statutes, the common law position remains. No one can build a castle for military defence. It is asserted that this prohibition is obsolete today for the following reasons:

- Castles (fortresses) are long obsolete militarily. Modern castles have been built (and re-constructed) without the need for permission from the Crown (albeit it might be argued these were for private residences and not for military purposes); ${ }^{270}$

- It is exceedingly unlikely that an individual, today, would seek to build a castle (fort) for a military purpose. Any such construction would require planning permission - the grant of which is improbable. Further, the cost of erecting such a castle would also be likely prohibitive;

- The rationale for such a prohibition - that such a castle might threaten the military might of the sovereign - has long gone. The sovereign is no longer in command of the military, being a constitutional monarch. And such a castle would hardly threaten the Ministry of Defence and the armed forces.

In conclusion, any common law prohibition on a subject building a castle or a bulwark is otiose. The rationale for it no longer applies. Castles are obsolete militarily. In any case planning permission would be required for a castle for military purposes, which is unlikely to be granted.

\footnotetext{
${ }^{261}$ Coke, n 7, vol 2, p 29 'But the making of bulwarks, fortresses, and other things of like kind, were not prohibited by this act [Magna Carta, 1297, ch 15] because they could not be erected, but either by the king himself, or by act of parliament.' Chapter 15 provided that 'No town nor freeman shall be distrained to make bridges nor banks, but such as of old time and of right have been accustomed to make them in the time of king Henry our grandfather'. The reference is to Henry II (1154-89). See also McKechnie, n 71, pp 299-304.

${ }^{262}$ See ns 254 \& 260. The Oxford English Dictionary (OED) (castle) 'castellum in sense fort, fortress.' 'A large building or set of buildings fortified for defence against an enemy; a fortress, stronghold.' See also Coke, n 7, vol $15^{\text {a }}$ (reference to Domesday Book 1086 in which a castle is called a 'castellum, and castrum, and domus defensibilis, and mansus muralis).'

${ }_{263}$ Ibid (bulwark) 'A substantial defensive work of earth, or other material; a rampart, a fortification.'

${ }^{264}$ See extract on 'Castles' New Encyclopedia Britannica (2007). Micropedia, vol 2.

265 Ibid.

${ }^{266}$ The reason this is asserted is that the initial prohibition almost certainly only related only to castles (i.e. fortified houses). Cf. Clode, $n$ 237, p 7, n 6 cites Henry V's (1413-22) Articles of War (promulgated between 1415-21). They forbade any man to edify or strengthen any manner of place without the special licence of the sovereign or his council.

${ }^{267}$ Chitty, n 10, p 45. See also Clode, n 237, p 3 citing Oliver St John (counsel) in $R v$ Hampden (1637) 3 ST 825 'no man without commission, or special licence from his majesty can....unless upon sudden coming of enemies, erect a fort, castle, or bulwark, though upon his own ground.'

26813 Car 2 st 1 c 6 (1661, rep) 'Forasmuch as within all his Majesty's realms and dominions the sole supreme government, command, and disposition of the militia, and of all forces by sea and land, and of all forts and places of strength is, and by the laws of England ever was the undoubted right of his Majesty and his royal predecessors, Kings and Queens of England, and that both or either of the Houses of Parliament cannot nor ought to pretend to the same.'

26914 Car 2 c 3 (City of London Militia, rep). He cites Coke, n 7, vol 2, p 30 (castles in the time of Henry II, 1154-89). Also, vol 1, $5^{\text {a }}$ (see $n$ 255).

${ }_{270}$ The last castle built in England appears to be Castle Drogo in Devon, built 1910-20's.
} 


\section{(b) Subject Building Fortifications - War Time}

An exception to the prohibition on a subject building a castle was confirmed in Malverer $v$ Spinke (1537): ${ }^{271}$

in some cases a man may justify the commission of a tort, and that is in cases where it sounds for the public good; as in time of war a man may justify making fortifications on another's land without licence...for [this is a case] of the common weal.

Similarly, in the King's Prerogative in Saltpetre (1606), ${ }^{272}$ the judges held that:

by the common law, every man may come upon my land for the defence of the realm, as appears 8 Ed 4 $23 ;{ }^{273}$ And in such case on such extremity they may dig for gravel, ${ }^{274}$ for the making of bulwarks; for this is for the public, and everyone hath benefit by it; but after the danger is over, the trenches and bulwarks ought to be removed, so that the owner shall not have prejudice in his inheritance.

The case in the reign of Edward IV (1461-70 and 1471-83) referred to is one in 1468. Here, counsel asserted there was such a custom in Kent for the defence of the sea coast. ${ }^{275}$ However, the case did not decide the issue. In similar vein, an Act of 1512 (repealed) provided for justices of the peace to order the erection of bulwarks because of the danger of invasion of the coast of Cornwall. Thus, it was lawful:

for every of the king's subjects within this realm of England by the advice and assignment of the said justices of the peace or sheriff to make all manner of bulwarks...in every man's ground of what estate or degree he be of and also to dig and to delve as well for earth stones and turves as to cut and to hew heath [heth] in any man's ground for the making of any such bulwarks ... as often and as many times as need shall require, and the said earth stones turves and heath to take occupy and carry away out of the said ground to any other man's ground for the making of any such bulwarks. (spelling modernised) ${ }^{276}$

In such a case no compensation was payable. This Act, being repealed, the common law position remains. Today, it is asserted that any right of a subject to establish fortifications on the land of another - which right is actually a franchise of a Crown prerogative to do the same - should be abolished, for the following reasons:

- $\quad$ Job of the Armed Forces. Today, the country has armed forces. They would undertake the erection of fortifications on the land of a subject, for defence purposes. Thus, no right accorded to a subject is necessary;

- Legislation Employed. In the case of the First and Second World Wars (1914-8 and 1939-45), legislation was relied on for the erection of fortifications on the land of others, for defence purposes (see (c) below) - as opposed to any Crown prerogative. Further, individuals did not avail themselves of the right to dig on the land of others, for defence purposes;

- Caselaw Indeterminate. This right is not well established in caselaw since the case cited in 1468 (see above) was only was asserted to apply to the coast of Kent. Further, no decision upholding such a right in that case appears to have been reached;

\footnotetext{
271 Dyer 35 (73 ER 79) at 35b. Cited in Clode, n 237, p 2.

27212 Co Rep 12 at 13 (77 ER 1294). Also cited in Clode, n 237, p 2.

273 YB 8 Edw 4 pl 41 fo $23^{\mathrm{a}}$, Seipp Index 1468.074 (see n 60 for Index). See also Brooke, n 5, Custom. See also a case of trespass for taking grain in the court of Common Pleas in 1506 (Seipp Index 1506.053) in which Kingsmill JCP stated (trans Seipp) 'in time of war (temps de guerre, wartime) one will justify the entry onto another's land to make a bulwark in defence of the king and of the realm, and those things are justifiable, and lawful for the maintenance of the common good (de le comon wealth).' See also Chalmers \& Asquith, $\mathrm{n}$ 12, pp 165-6.

274 The case notes, however, that the sovereign 'cannot take gravel in the inheritance of the subject, for reparation of houses.' OED, n 262 (gravel)

${ }^{275}$ Seipp (n 60) translates the law French as 'Defendant pleaded that there was a custom in the county of Kent that when any enemies came to the seacoast, that all those of Kent could well come onto the land adjoining the same seacoast in defence and safeguarding of the country (pais), and there to make their trenches and bulwarks for the defence of the same country (pais), and that at the time of the same trespass enemies came, and defendant thus justified. Plaintiff (?) replied that this was common law (so defendant should be driven to plead 'not guilty' (?). Defendant (?) rejoined that defendant could not dig in plaintiff's land unless there was such a usage (custom).'

2764 Hen 8 c 1 (1512) (Bulwarks, Braies, Walls, and other Fortifications shall be made by the Sea-Side in Cornwall by the Justices of the Peace Assignment). See also 2 \& 3 Phil \& Mar c 1 (An Act for the Re-edifying of Castles and Forts and for the enclosing of Grounds from the Borders towards and against Scotland, rep). OED, n 262 (heath) 'tract of land naturally clothed with low herbage and dwarf shrubs.'
} 
- Right does not Apply to Non-Subjects. The right under the common law derives from the concept of allegiance. ${ }^{277}$ Thus, it only applies to subjects. There would seem to be no such right in the case of a non-subject. Nor for the erection of fortifications on the land of a non-subject;

- Crown's Right re Gravel. The Crown's prerogative to dig - and take - gravel from the land of subjects (but, it seems, not non-subjects) is also unnecessary today and should be abolished.

If the right (licence from the Crown) of a subject to enter the land of another subject in order to erect fortifications thereon for the defence of the realm was abolished then - if required in the future (which is most unlikely) - such matters would be left to legislation (which would, doubtless, specify for the armed forces to undertake the same). This is appropriate. Abolition of such a right would have no, modern day, effect since individuals do not take it on themselves (and did not in two World Wars) to establish fortifications.

In conclusion, such a right should be abolished. There is no need, in modern times, for a subject to be given the right to build fortifications on another subject's land during wartime.

\section{(c) Crown's Prerogative to Erect Fortifications}

Halsbury states:

In time of war the Crown may enter on the land of a subject, for example to erect fortifications or to dig for saltpetre, but in both the 1914-18 and 1939-45 wars special powers were conferred by statute and regulations to take necessary action with regard to the requisition of property, the entry on land and many other national needs, and the wide scope of those powers rendered unnecessary recourse to the royal prerogative. ${ }^{278}$ (wording divided for ease of reference)

As to the digging for saltpetre for gunpowder, see 12. Caselaw for the Crown prerogative to erect fortifications is the King's Prerogative in Saltpetre $(1606)^{279}$ where the judges stated:

when enemies come against the realm to the sea coast, it is lawful to come upon my land adjoining to the same coast, to make trenches or bulwarks for the defence of the realm, for every subject hath benefit by it. ${ }^{280}$

It is asserted this Crown prerogative is obsolete and that it should be abolished for the following reasons:

- No need to Erect Fortifications on Subject's Land. Today, there are professional armed forces and a Ministry of Defence which possesses extensive areas of land set aside for military purposes, such that the need to erect defensive fortifications on a subject's land (especially one adjoining the coast) is not necessary;

- Crown Prerogative Insufficiently Wide. The Crown prerogative is insufficiently wide. It covers only the erection of fortifications on the land of subjects - the protection of the same from foreign enemies is corollary to the allegiance owed by the subject to the Crown for the same. Thus, it would seem the prerogative cannot be exercised on land belonging to foreigners, unless it can be shown that they owe some form of 'local' allegiance; ${ }^{281}$

- Emergency Powers. The Civil Contingencies Act 2004 enables regulations to be made which make provision (which may include conferring powers in relation to property) for facilitating any deployment of Her Majesty's armed forces. ${ }^{282}$ This would seem to cover erecting fortifications on a subject's land, to be manned by military personnel;

- Legislation Utilised. As in the case of the First and Second World Wars, ${ }^{283}$ legislation to erect defensive fortifications on the land of others (whether subjects or not) is more appropriate than reliance on a Crown prerogative which is uncertain in scope.

\footnotetext{
277 That is, the allegiance of subjects to provide for the defence of the realm.

278 Halsbury, n 1, para 812. See also Warren v Smith, Magdalen College Case (1615) 1 Roll Rep 151 at 152.

27912 Co Rep 12 at 13 (77 ER 1294).

280 At p 12. See also Warren v Smith or Magdalen Colledge Case (1615) 1 Roll Rep 151 (81 ER) at 152 'le roy ne poet aver ceo a faire fortifications que est allowe per la ley en assun terre come en $18 \mathrm{Ed} 4$.' The reference to 18 Ed 4 would seem to be a mis-reference to 8 Edw 4 , see n 273.

281 See $n 113$

282 Civil Contingencies Act 2004, s 22(3) (m). See also (c) 'provide for or enable the destruction of property.'

283 See n 279.
} 
In any case, it should be laid down in legislation and a concomitant should be the payment of compensation.

In conclusion, a common law prohibition on subjects erecting castles for defensive purposes should be abolished. It is both obsolete and unnecessary since persons do not now erect castles for military purposes. The right of subjects (or, rather, a Crown franchise accorded to subjects) to enter the land of other subjects in order to erect fortifications there for the defence of the realm in war time should also be abolished. This should be left to legislation, if ever required in future. Finally, any Crown prerogative to so erect such fortifications should be abolished, being replaced by legislation - where required.

\section{Proclamations}

The Crown is directly involved in the enactment of legislation since the body charged with the same is the Queen in Parliament (known as the 'Parliament of the United Kingdom of Great Britain and Northern Ireland') which consists of the sovereign, the House of Lords and the House of Commons. ${ }^{284}$

- As Halsbury notes, in practice, the sovereign now plays only a formal role in the making of legislation since she has lost the power of refusing her assent to a bill passed by both Houses (or by the Commons alone when pursuant to the Parliament Acts 1911 and 1949). ${ }^{285}$

Whether this direct involvement of the sovereign in legislation can be accurately termed a Crown prerogative is debatable. ${ }^{286}$ However, what is a Crown prerogative - is the ability of Crown to enact subordinate legislation in the form of proclamations. These are legally binding on the subject only when they do not contradict the laws or tend to establish new ones ${ }^{287}$ - but enforce the execution of those in being. ${ }^{288}$ Thus, Blackstone opined:

proclamations, are binding upon the subject, where they do not either contradict the old laws, or tend to establish new ones; but only enforce the execution of such laws as are already in being, in such manner as the king shall judge necessary. ${ }^{289}$

Halsbury states:

In general, proclamations may legally be made and issued only by the authority of the Crown, and must be passed under the Great Seal, ${ }^{290}$ and no private person may make and issue a proclamation, unless the practice is warranted by custom, ${ }^{291}$ or unless he is expressly authorised to do so. ${ }^{292}$ Breach of this provision is punishable by fine and imprisonment. ${ }^{293}$

\footnotetext{
${ }^{284}$ Halsbury, n 1, para 17. Also, para 21.

${ }^{285}$ Ibid. Where a bill affects royal interests or the royal prerogative - by convention - the consent of the sovereign is required.

${ }^{286}$ It is debatable since the legitimacy of legislation (unlike in the past) today derives from Parliament and not from any assent given by the sovereign, which assent she cannot refuse.

${ }_{287}$ As Chitty notes, n 10, p 3 'the Crown has no power to propound laws.'

${ }^{288}$ Blackstone, n 8, vol 1, pp 260-1. Comyns, n 6, vol 7, p 48 'the king by his proclamation may enforce the execution of laws. And, therefore, if the king by proclamation prohibits that which was before unlawful, the offence afterwards will be thereby aggravated. So, the king by his proclamation may admonish his subjects, that they do not offend, under the penalty of the law.' Fortescue, n 254 , p 17 'the king of England is not able to change the laws of his kingdom at pleasure, for he rules his people with a government not only royal but also political. If he were to rule over them with a power only royal, he would be able to change the laws of the realm, and also impose on them tallages and other burdens without consulting them; this is the sort of dominion where the civil laws indicate when they state that 'What please the prince has the force of law.' See also pp 27, 48, 52, 54. See also the Statute of Proclamations (1539) 31 Hen 8 c 8 (rep), s 2 (proclamations shall not prejudice estates, offices, liberties, goods or lives or repeal any existing laws). For commentary on this Act, see Munro, n 12, p 263. See also Chitty, n 10, p 104 who thought that proclamations were probably 'adopted for the purpose of giving additional weight and dignity to the laws.' Hale, n 10, p 172 'The king...cannot by [proclamation] make or introduce a new law or add a new penalty to an old law or abrogate any law. Their use is especially in promulgating or publishing a new law.'

${ }_{289}$ Blackstone, $\mathrm{n} 8$, vol 1, p 261. The precursor of the Proclamation in medieval times was the Ordinance, see Anson, n 11, vol 1, pp 256-8.

${ }^{290}$ Keyley v Manning (1630) Cro Car 180 (79 ER 758). Comyns, n 6, vol 7, p 48 'every proclamation ought to be sub magno sigillo angliae.' See also Chitty, n 10, p 106.

${ }^{291}$ As to warranty by custom, Chitty, n 10, p 105 states 'a subject as a mayor of a town, etc. may by custom, ratione privilegii, possess this right.' An example is the proclamation issued by members of the Privy Council announcing the accession of a new sovereign. Halsbury, $\mathrm{n} 1$, para 916, n 2. Also, para 40.

${ }_{292}$ Case of Proclamations (1611) 12 Co Rep 74, 76 (77 ER 1352).

${ }^{293}$ Halsbury, n 1, para 916. Knightley’s Case (1530) Hob 74 (80 ER 224). Sir Edmund Knightley, acting as an executor, made and issued a proclamation that the creditors of the deceased were to come in and prove by a certain day. He was fined and imprisoned since it was held that he had no public authority to do so). Comyns, n 6, vol 7, p 48 'none can make proclamation, but by the authority of the King, or lawful custom; for it is the prerogative of the king to issue proclamations.' The ODNB, n 60, says of Sir Edmund Knightley (d. 1542) 'The following years he became involved in a dispute with the Crown over some property, and after making 'proclamations' slandering the king's title [the king was Henry VIII, 1509-47] he was in September 1532 committed to the Fleet by the 'Lord Chancellor' (presumably Lord
} 
A proclamation is valid when published in the relevant Gazette. ${ }^{294}$ When legally made - and issued - a proclamation is to be judicially noticed and it possesses the same validity as an Act of Parliament. Proclamations are treated as a form of subordinate legislation; any breach of their provisions is punishable by a fine and imprisonment. $^{295}$

\section{(a) Restrictions on Making Proclamations}

\section{Halsbury states:}

Under the general rule which restrains the Crown from legislating apart from Parliament, it is well settled that the monarch's proclamation, unless authorised in that behalf by statute, cannot enact any new law, or make provisions contrary to old ones. The monarch's proclamation may not restrict the liberties of the subject in matters upon which the law is silent. ${ }^{296}$

In the Case of Proclamations (1611) it was held that:

the king by proclamation cannot create any offence which was not an offence before, for then he may alter the law of the land in his proclamation in a high point...the law of England is divided into three parts, common law, statute law, and custom; but the king's proclamation is none of them...The king hath no prerogative, but that which the law of the land allows him...But the king for the prevention of offences may by proclamation admonish his subjects that they keep the laws, and do not offend them; upon [punishments] to be inflicted by the law, etc. ${ }^{297}$

Thus, it was held in this case, that the sovereign (James I, 1603-25) could not by proclamation prohibit the erection of new buildings in - and about - London; nor the making of starch from wheat. ${ }^{298}$ When Coke reported this case, he admitted that a number of proclamations made in the past were void since they purported to constitute legislation that made, or altered, the law. ${ }^{299}$ This seems to have commenced in the reign of Henry VIII $(1507-49) .{ }^{300}$ Further, Tanner notes:

Keeper Audley.' See also Brooke, n 5, Proclamations, pl 10. Chitty, n 10, p 105 'Sir Edward [sic] Knightley, executor of Sir William Spencer, who was fined and imprisoned for making public proclamation in certain market towns, publicly and without any authority, that the creditors of the deceased should come in by a certain day and prove their debts.'

${ }^{294}$ In the case of England, Scotland and Northern Ireland in the London, Edinburgh and Belfast Gazettes. See Halsbury, n 1, para 916. See also The Crown Office (Forms and Proclamations Rules) Order 1988/1082.

${ }^{295}$ Case of Proclamations (1611) 12 Co Rep 74, 76 (77 ER 1352). Cf. H Hallam, The Constitutional History of England (London, John Murray, 1897), vol 1, p 337 quoting Dalison's Reports 20 'The king, it is said, may make a proclamation, quoad terrorem populi, to put them in fear of his displeasure, but not to impose any fine, forfeiture, or imprisonment; for no proclamation can make a new law, but only confirm and ratify an ancient one.' See also Finch, n 69, p 75 and Fitzherbert (1794 ed), n 141, p 189, 85c (fine for contempt of the sovereign's command).

296 Ibid, para 918. Case of Proclamations (1611) 12 Co Rep 74, 76 (77 ER 1352. The sovereign's proclamations were issued in - and with the advice of - her privy council. See Creasy, n 11, p 282. See also Hewart, n 65, pp 116-7.

${ }^{297}$ Case of Proclamations (1611) 12 Co Rep 74, 76 (77 ER 1352). Comyns, n 6, vol 7, p 48 'the king cannot, by his proclamation, make a thing unlawful, which was before lawful; for the King cannot create an offence, by proclamation. And therefore nothing will be punishable after a proclamation, which was not so before. So, he cannot by proclamation alter any part of the common law, statutes, or customs of the realm. And therefore a proclamation for the suspension of the execution of a statute, till the next parliament, is illegal and void. A proclamation that none import wines of such a country, which is in amity [with England], under the paid of forfeiture, will be void [citing Coke, n 7, vol 2, p 63]. A proclamation that the buyer of a horse in a fair or market, or out of a fair or market, in the county of $\mathrm{N}$ do not pay toll, his horse shall be forfeited, is void. Semble but not determined.' He refers to Rolle, n 5, vol 2, p 172. See also Halsbury, n 1 , para 7, n 3.

298 Ibid, at p 75. Dicey, n 11, p 53 'In $1610 \ldots$ a solemn opinion or protest of the judges [this case] established the modern doctrine that royal proclamations have in no sense the force of law; they serve to call the attention of the public to the law, but they cannot of themselves impose upon any man any legal obligation or duty not imposed by common law or Act of Parliament.' See also Hallam, n 295 , vol 1 , p 337 who notes that several proclamations against building in London were later made, as well as prohibiting country gentlemen to live in London.

299 At p 75 'But we do find divers precedents of proclamations which are utterly against law and reason, and for that void.' In particular, Coke cites a proclamation of Henry IV (1399-1413) in 1407 in which the sovereign ordered the suspension of an Act (by which foreigners were licensed to merchandise within London) until the next Parliament 'which was against the law.' Coke also cited Holinshed, at $\mathrm{p} 722$ who noted that Henry VIII (1509-47) in 1546 suppressed whore houses (the stews) in London by means of a proclamation and the sound of the trumpet. This reference is to R Holinshed, The Chronicles of England, Scotland and Ireland $\left(1^{\text {st }}\right.$ ed $1577,2^{\text {nd }}$ ed 1587). For this proclamation, see Hughes \& Larkin, n 239, vol 1, p 365-6 (Proclamation of 13 April 1546 ordering London Brothels Closed). See also Hallam, n 295, vol 1, pp 236-8 (proclamations of Elizabeth I (1558-1603), pp 298-9, 327-9 (James I, 1603-1625) and vol 2, pp 25-6 (Charles I, 1625-49), 'The illegality of these proclamations is most unquestionable.'). See also Chitty, n 10, p 105. Also, Vicenzi, n 12 , p 21 referring to a proclamation of Elizabeth I (1558-1603) in 1601 which commanded all 'blackamoors'[negros] to depart from the kingdom. See also Tanner, $\mathrm{n} 13$, pp 28, 37 and Anson, n 12, vol 2, pt 1, pp 40, 42-3.

300 SB Chrimes, Henry VII (University of California Press, 1972), pp 175-7 reviewed 62 proclamations issued in the reign of Henry VII (1485-1509). He concluded that Henry did not resort to proclamations in order to 'add significantly to the law' (25 were of a general administrative nature, 10 related to money and coinage, 6 to the regulation of trade and 11 were related to truces, treaties, peace, war and courtesies to foreign potentates). 
In a petition of 7 July, 1610 the Commons complained that proclamations had been issued creating new offences unknown to the law; imposing penalties for known offences greater than those authorised by law; and requiring accused persons to be brought before tribunals which were not legally authorised to try their offence. In his answer to the petition the king undertook to consult the judges. ${ }^{301}$

Their reply - the Case of Proclamations (1611) - in effect, ${ }^{302}$ reduced proclamations to a form of subordinate legislation which did little more than confirm the existing law; robbing it of much efficacy it formerly had. ${ }^{303}$ The result was to severely limit the power of the Crown in using proclamations. This was reflected in their subsequent, reduced, usage.

\section{(b) Proclamations as Legislation}

The last case where the Crown sought to legislate by proclamation was in 1766 . To prevent famine - and Parliament not being assembled - an embargo was laid on all ships laden with wheat and flour in time of peace. This was contrary to express statutory provisions. The action of the Crown was later defended by Lord Camden, the Lord Chancellor, on the ground of necessity. ${ }^{304}$ However, being unlawful, an Act of Indemnity was needed. ${ }^{305}$ The Oxford Dictionary of National Biography states in respect of this incident:

As a politician the new Lord Chancellor was soon exposed to criticism that questioned his role as a champion of liberty against State power. A parliamentary ban on the export of corn on 26 August 1766, and the combination of a poor harvest and the resumption of exports provoked widespread disorder through fears of high prices and of possible starvation. The Chatham ministry, acting through the privy council and with the support of Lord Chancellor Camden, decided upon a royal proclamation of 26 September prohibiting corn exports until, after Parliament met on 11 November. But the action breached the 1689 Bill of Rights provision that forbade the Crown to suspend laws, and the matter was promptly raised in both Houses of Parliament. Camden found Chatham and himself accused of tyrannical behaviour. The plea of necessity, so contrary to Chatham's own famous legal opinion of the previous year, did not allay parliamentary resentment, especially when Camden unwisely claimed that it had been only 'a forty days tyranny', and the ministry had to pacify criticism by the humiliation of an act of indemnity. ${ }^{306}$

\section{(c) When Proclamations Are Issued}

In Tudor (1485-1603) and Stuart times (1603-88), proclamations (all now spent) were categorised by Holdsworth as covering - in the main- matters relating to:

(i) the administration of government;

(ii) religion;

(iii) commercial and industrial regulations;

\footnotetext{
${ }^{301}$ Tanner, n 13, pp 37-8. See also Holdsworth, n 9, vol 4, pp 296-7 (he considered the type of proclamations issued during the Tudor and Stuart periods. All are now obsolete).

${ }^{302}$ Coke would not have seen in detail Tudor Royal proclamations of 1485-1603. However, many of them, in essence, comprise primary legislation. See also Hughes \& Larkin, n 239.

${ }^{303}$ This case may be seen as part of Coke's own personal struggle with James I (1603-25) a sovereign who held a high opinion of his prerogative. The case, as reported by Coke, also very much reflects his own opinions. Holdsworth, n 9, vol 11, p 281 'This ruling in effect confined their [i.e. proclamations] operative force to the sphere of executive government, so that a statute passed by Parliament was the only means of making even the smallest modification in the law. The Revolution [of 1688] put the finishing touch to this development by finally divesting the prerogative of the supra-legal sanctity which the royalists had claimed for it.'

${ }^{304}$ Halsbury, n 1, para 918. Dicey, n 12, p 53 'In 1766 Lord Chatham attempted to prohibit by force of proclamation the exportation of wheat, and the Act of Indemnity passed in consequence of this attempt, may be considered the final legislative disposal of any claim on the part of the Crown to make law by force of proclamation.' See also Heuston, $\mathrm{n} 11, \mathrm{p} 75$.

${ }^{305}$ Chitty, n 10, pp 164-5 'This embargo...was declared illegal by the...Act [of Indemnity].' See also Holdsworth, n 9, vol 10, p 365.

${ }^{306}$ ODNB, n 60, Charles Pratt, 1st Earl Camden. The satirist Junius, n 82, vol 2, p 163 noted caustically 'With regard to Lord Camden, the truth is, that he inadvertently overshot himself, as appears plainly by that unguarded mention of a tyranny of forty days, which I myself heard. Instead of asserting, that the proclamation was legal, he should have said, 'My lords, I know the proclamation was illegal; but I advised it, because it was indispensibly necessary to save the kingdom from famine; and I submit myself to the justice and mercy of my country.' Such language as this would have been manly, rational, and consistent: not unfit for a lawyer, and every way worthy of a great man.' See also Amos, n 12, pp 122-3.
} 
(iv) social life;

(v) the press;

(vi) miscellaneous.

It may be noted that all these matters, today, are now - invariably - dealt with by way of Statutory Instrument ${ }^{307}$ -save for (ii) which is no longer applicable, given religious tolerance. ${ }^{308}$ As for proclamations issued post-1800, these have mainly been issued in order to: ${ }^{309}$

(a) Call attention to the provisions of existing laws; ${ }^{310}$

(b) Make (or alter) regulations over which the Crown has a discretionary authority either at common law or by statute; ${ }^{311}$

(c) Summon (i.e. call) - or dissolve - Parliament; ${ }^{312}$

(d) Declare war or peace; $;^{313}$

(e) Promulgate blockades and lay embargoes on shipping in time of war; ${ }^{314}$

(f) Put in force statutory provisions which would otherwise remain dormant, when the Crown is authorised by legislation so to do. ${ }^{315}$ This includes proclamations prohibiting the import (or export) of explosives, arms, ammunition etc. ${ }^{316}$

(g) Issue proclamations in the case of a state of emergency; ${ }^{317}$

(h) Prohibit subjects from leaving the realm. ${ }^{318}$ (It is asserted this prerogative is obsolete, see 12).

(i) Impose martial law. ${ }^{319}$ (It is asserted this prerogative is obsolete, see 12).

(j) Regulate coinage. ${ }^{320}$

(k) Change a royal title. ${ }^{321}$

Halsbury notes that those in (d)-(i) -being created for the public safety - are strictly limited by necessity. ${ }^{322}$ In the case of (d) and (i) it may also be noted that a proclamation of war - or of martial law ${ }^{323}$ - is not actually

${ }^{307}$ Holdsworth, n 9, vol 11, p 283 'At the present day [he was writing in 1938] these rules, orders, or regulations cover all and more than all of the sphere occupied by proclamations in the Tudor and early Stuart period'

308 Ibid, vol 4, pp 296-7, vol 6, pp 31, 303-12. See also R Steele, A Bibliography of Royal Proclamations of the Tudor and Stuart Sovereigns and of Others Published under Authority 1485-1714 (4 vols). As Holdsworth notes, n 9, vol 6, p 31 the later Stuarts tended not to issue proclamations which had the effect of making law mainly because the abolition of the Star Chamber in 1641 'deprived them of the means of enforcing proclamations which went beyond the limits laid down by the Case of Proclamations.'

${ }^{309}$ For others, such as to grant letters of marque and reprisal, now obsolete, see Chitty, n 10, p 105. See also Hale, n 10, pp 172-3.

310 Halsbury n 1, para 917, n 1 states 'e.g. in the case of war between two States friendly to the United Kingdom, to the provisions of the Foreign Enlistment Act 1870...see the Proclamation of Neutrality dated 11 February 1904, SR \& O 1904/201, issued in connection with the Russo-Japanese War.' This use of proclamations would be most unlikely to occur in modern times, where the authority of the Crown is not needed to endorse legislation, whether primary or secondary.

311 Blackstone, n 8, vol 1, pp 260-1 and Chitty, n 10, pp 104-6. See also Bacon, n 6, vol 7, p 48, Prerogative D 2. Also, Case of Proclamations (1611) 12 Co Rep 74, 76 (77 ER 1352).

${ }_{312}$ Halsbury, n 1, para 917. See also Prorogation Act 1867 and Meeting of Parliament Acts 1797 \& 1799.

313 Ibid. See also paras 809-10.

314 Ibid, para 817. Blackstone, n 8, vol 1, p 261 'Thus the established law is, that the king may prohibit any of his subjects from leaving the realm: a proclamation therefore forbidding this in general for three weeks, by laying an embargo upon all shipping in time of war, will be equally binding as an act of parliament, because founded upon a prior law.' See also Sands v Child (1693) 4 Mod 177 (87 ER 332 ) (process issued by the court of Admiralty to stop the sailing of a ship on the basis of its departing on an illegal voyage). See also Chitty, $\mathrm{n} 10$, $\mathrm{p} 105$.

315 Ibid, para 917, n 9 'e.g. the Criminal Law and Procedure (Ireland) Act 1887 (rep).' This would now be done by Statutory Instruments.

316 Ibid, para 818 .

317 Ibid, para 822

318 Ibid, para 917. See also GS McBain, Abolishing Obsolete Crown Prerogatives relating to the Military (2011) Nottingham LJ, vol 20, at pp 26-33.

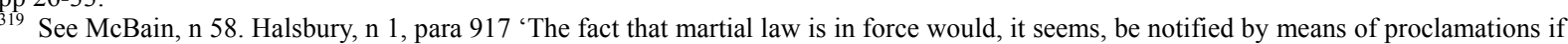
such a course were rendered necessary by a state of war and there is authority for their use to restrain persons from leaving the realm in time of war, in order to prevent their rendering assistance to the enemy; but these and other similar prerogatives in time of war, being created for the public safety, are strictly limited by necessity.'

320 See Coinage Act 1971, s 3 (as amended). Also, Sunkin, n 12, p 344. See also Currency Act 1983.

321 Royal Titles Act 1953.

${ }^{322}$ Halsbury, n 1, para 917. See also Lord Erskine, Parliamentary Debates (1808), vol 10, p 961.

323 See McBain, n 58, n 199. See, in particular, a Joint Opinion delivered in 1838 by the Attorney General (Sir John Campbell) and the Solicitor General (Sir RM Rolfe) as to the power of the Governor of Canada to proclaim martial law. They noted that - whether a proclamation of martial law was made or not - was irrelevant to the state of affairs. At $\mathrm{p} 198$ 'such proclamation confers no power on the Governor which he would not have possessed without it. The object of it can only be to give notice to the inhabitants of the course which the Government is obliged to adopt for the purpose of restoring tranquility.' 
necessary in order for the same to be effective (further, today, war is rarely proclaimed). As to whether any of (a)-(j) need - or should - be by way of proclamation today, see (d) below.

\section{(d) Abolishing Prerogative to Make Proclamations}

It is asserted the Crown's prerogative to make proclamations should be abolished, save in respect of summoning, and dissolving, Parliament. ${ }^{324}$ The reasons for this are as follows:

- Democracy. Proclamations comprise an anomalous form of quasi-legislation since they do not have the sanction or approval of Parliament. In terms of a modern democracy, this is not appropriate;

- Superceded by Statutory Instruments. Proclamations are not necessary in modern times, since their role has been superceded by Statutory Instruments (SIs), which require Parliamentary sanction. Thus, proclamations are not required - and would not now be issued - in order to 'call attention to the provisions of existing laws.' (see (c)(a) above). Further, in the case of all of (c)(b)-(j), these should be by way of SI, requiring Parliamentary approval. The only case where a proclamation should be used in modern times should be to summon or dissolve Parliament (see (c)(c) above);

- Inappropriateness of the Punishment. It is dubious whether the courts would be prepared, in modern times, to fine or imprison persons (up to life imprisonment) for failing to obey a proclamation.

Further,

- Private Persons making Proclamations. There is no need for private persons to make proclamations today, and it is not appropriate that private persons make legislation; ${ }^{325}$

- Provisions of Existing Laws. There is no need, today, for proclamations to call attention to the provisions of existing laws (see (c)(a) above);

- Make or Alter Regulations. There is no need for proclamations to make (or alter) regulations in respect of which the Crown has a discretionary authority either at common law or by statute (see (c)(b) above). Such should be dealt with by SIs - where required - which allocate discretion to specific Government departments; ${ }^{326}$

- Prohibiting Subjects Leaving Realm. The Crown prerogative to prohibit subjects from leaving the realm (see (c)(h)) is, in any case, obsolete and that (it is asserted) it could not be enforced, today; ${ }^{327}$

- Legislation Authorising Regulations. When the Crown is authorized by legislation to put into effect (force) statutory provisions which would otherwise remain dormant (including proclamations prohibiting the import or export of explosives, arms, ammunition etc, see (c)(f)) such proclamations do not arise by way of the Crown prerogative but pursuant to statute. So too, proclamations that might be issued in a state of emergency. ${ }^{328}$ Thus, abolition of the Crown prerogative to issue proclamations will not affect any proclamations subsequently issued pursuant to legislation;

- States of Emergency - Regulations. Powers relating to states of emergency are governed by the Civil Contingencies Act 2004. It covers emergencies such as war and terrorism and it permits regulations to be made without a state of emergency having to be declared or Parliament having to agree to the same. The ambit of these regulations is extensive. ${ }^{329}$ Thus, in the case of emergency, SIs are preferred to proclamations;

\footnotetext{
${ }^{324}$ Cf. Dicey, n 12, pp 53-4 'The main instances where, in modern times, proclamations or orders in council are of any effect are cases either where, at common law, a proclamation is the regular mode, not of legislation, but of announcing the executive will of the king, as when Parliament is summoned by proclamation, or else where orders in council have authority given to them by Act of Parliament.'

325 The proclamation of a new sovereign is not actually that. It is more an announcement. The Privy Council cannot, in itself, declare a person to be sovereign. That person can only be so if they satisfy the requirements of legislation. For example, pursuant to the Bill of Rights 1688 .

${ }^{326}$ In 1820 , Chitty, n 10, p 104 endorsed the reasonability of proclamations and their public advantage because "though the making of laws is entirely the work of a distinct part, the legislative branch of the sovereign power, yet the manner, time, and circumstances of putting those laws into execution, must frequently be left to the discretion of the executive magistrate [i.e. the sovereign].'

327 See McBain, n 54. It may be noted that, in Sands $v$ Child (1693) 4 Mod 177 (87 ER 332) p 179, counsel noted: 'as to the writ ne exeat regno, it is only granted, and that very rarely too, to prohibit a single person from departing the kingdom.' Thus, by 1693 (over 320 years ago) a writ of ne exeat regno was rare.

328 See $n 329$

329 See McBain, n 58, pp 48-9.
} 
- Last Case of Punishment. When a person was last punished by imprisonment or even a fine for disobeying a proclamation is unclear. Likely, it was a long time ago. ${ }^{330}$

In conclusion, the Crown prerogative to issue proclamations should be abolished. It comprises a power to make legislation which exists without the sanction of Parliament and, as such, it is not appropriate in a modern democracy. In any case, any proclamations issued should, in the future, only be pursuant to the terms of legislation (whether primary or SI). In practice, abolition of the prerogative to issue proclamations would change little. However, it would remove an anomaly in respect of legislation not otherwise being effected without the assent of Parliament.

\section{Conclusion}

In modern times we need modern law - law which is clear, comprehensive and understandable. ${ }^{331}$

- In the case of the Crown prerogative, this area of law is often obscure and uncertain ${ }^{332}$ as well as being based on a legal fiction that Crown prerogatives are still exercised by the Crown (or the sovereign) when, in fact, they are exercised by the Government. ${ }^{333}$ The retention of such a fiction can only have a negative impact on democracy; ${ }^{334}$

- A report of the House of Commons in 2004 asserted the case for the reform of - at least - some of the most significant Crown prerogatives was 'unanswerable. ${ }^{335}$ This applies, a fortiori, to minor Crown prerogatives.

It is asserted that the following Crown prerogatives should be abolished: ${ }^{336}$

- Common Law Courts. The prerogative to establish common law courts;

- $\quad$ Sovereign and her Courts. Any prerogative of the sovereign to: (a) sit as a judge; (b) withdraw any matter of State from the cognisance of any court; (c) request any judge to delay giving judgment; (d) sue in whatever court the sovereign pleases. Also, any common law rule as to costs affecting the sovereign in a personal capacity;

- Immunity of the Sovereign. Criminal immunity of the sovereign should be lifted - at least, in relation to major criminal offences - and civil immunity should be lifted in respect of: (a) any mortgage; pledge or lien granted by her over her own property; (b) any personal debt incurred by her;

- Obligation to accept a Public Office. Any prerogative to compel a person to accept a public office - or to act as a parish constable or a sheriff;

- $\quad$ Parens Patriae. Any prerogative to act as parens patriae. Any residual jurisdiction in respect of minors, the mentally disturbed and charities should pass to the relevant State institutions;

\footnotetext{
${ }^{330}$ Chitty, n 10, p 107. See also Armstead's Case (Hob 251).

$331 \mathrm{HC}, \mathrm{n} 3$, p 24 'Governments should not have imprecise powers. As a matter of basic constitutional principle the user of a power should be able - and if asked should be obliged - to identify the source of that power and to describe its nature and extent...the burden should be on the government to explain officially to Parliament and the public what prerogative powers it uses and how it uses them.' (Rod Brazier, specialist adviser to the Public Administration Select Committee of the House of Commons).

332 Burmah Oil Co v Lord Advocate [1965] AC 75 at p 148 per Lord Pearce 'The law and Parliament have so altered and curtailed (and in part confirmed) the various aspects of the prerogative that the whole subject is obscure and difficult.' Sunkin, n 12 , p 59 'the Crown as a legal concept has been strained to the point of incoherence.'

${ }^{333}$ Sedley, n 103, p 271 'The monarch is today constitutionally barred from playing any active part in those distinct functions of State.' The problem generally with fictions is that they are untrue. Finch, n 69, p 47 'Feigned construction (which we call fiction in law) is when in a simultudinary manner the law construes a thing otherwise than it is in truth.'

334 Ibid, p 77 contains a quotation from John Garrett MP 'The royal prerogative is an anachronism - an example of the overweening power of government over Parliament... The royal prerogative is a chilling manifestation of the way in which our democracy is deficient, and it should be mapped by the Select Committee on Procedure as soon as possible, and then largely ended.' J Straw, Power and the Throne (D

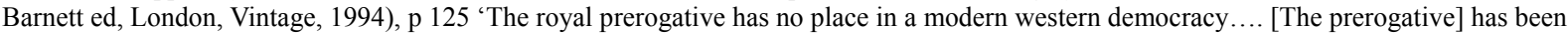
used as a smoke-screen by ministers to obfusticate the use of power for which they are insufficiently accountable.' See also HC, $\mathrm{n} 3$, $\mathrm{p} 8$.

${ }^{335} \mathrm{HC}, \mathrm{n} 3$, p 3. At p 15 'In April 2003, Parliament First, an all-party group of members, published proposals which would see 'the majority of prerogatives...placed on a statutory footing.'

${ }_{336}$ Sunkin, n 12, p 344 'A host of miscellaneous and relatively minor prerogatives are historical remnants, vague reminders of feudal times, and most of them have been affected in one way or another by statute. There seems little reason why these prerogatives should not be wholly replaced by statute as appropriate opportunities arise, and in some cases abolished.' Also, p 345 (formal review needed).
} 
- Making \& Declaring Peace. Any prerogative to make peace - including to declare peace. Legislation should provide for peace to be made - and declared - by means of a peace treaty (or other agreement) and that the same will take effect by way of SI, which also declares the date (and time) of peace;

- Making \& Declaring War. Any prerogative to make war - including to declare war. Legislation should provide for war - or any other form of military engagement - to be made (and declared) by Parliament and for the date (and time) of war to be specified in a SI. Such legislation should operate where the Civil Contingencies Act 2004 does not otherwise apply;

- Subordinate Military Prerogatives. Any prerogative to: (i) impress subjects for the navy; (ii) issue letters of reprisal and marque; (iii) issue letters of safe conduct; (iv) prohibit subjects from leaving the realm; (v) order subjects to return to the realm; (vi) dig for saltpetre (for gunpowder); (vii) impose martial law;

- Castles. Any prohibition on subjects building castles. Also, the right of subjects (or, rather, a Crown franchise accorded to subjects) to enter the land of other subjects to erect fortifications there for the defence of the realm in war time. Also, any Crown prerogative to so erect such fortifications. This should be replaced by legislation - where required;

- Proclamations. The Crown prerogative to issue proclamations. Any future proclamations should be specifically authorised by legislation (for example, the sovereign summoning, or dissolving, Parliament) or otherwise effected in the form of SIs.

One would assert the only case where there may be contention - or serious debate - as to the transfer of the above Crown prerogatives to Parliament, or their abolition, is that in respect of war. All the others are either obsolete or they would greatly benefit from being formulated in modern legislation. ${ }^{337}$ This would deepen democracy and recognise that the role of the sovereign in person in such matters is now only a formal one.

\section{Copyrights}

Copyright for this article is retained by the author(s), with first publication rights granted to the journal.

This is an open-access article distributed under the terms and conditions of the Creative Commons Attribution license (http://creativecommons.org/licenses/by/3.0/).

\footnotetext{
${ }^{337}$ Ibid, p 172 'As with so much concerning the Crown, it is tempting to dismiss these archaic laws as both harmless and unimportant. Neither is the case. The legal privileges and immunities of the Crown do matter. As Tom Nairn has demonstrated, the 'oh, don't worry, it's harmless, quaint and it doesn't really matter' school of thought is both inaccurate and dangerous, as those who peddle this themselves usually realise.' The quotation is from T Nairn, The Enchanted Glass: Britain and its Monarchy (London, Vintage, 1994).
} 